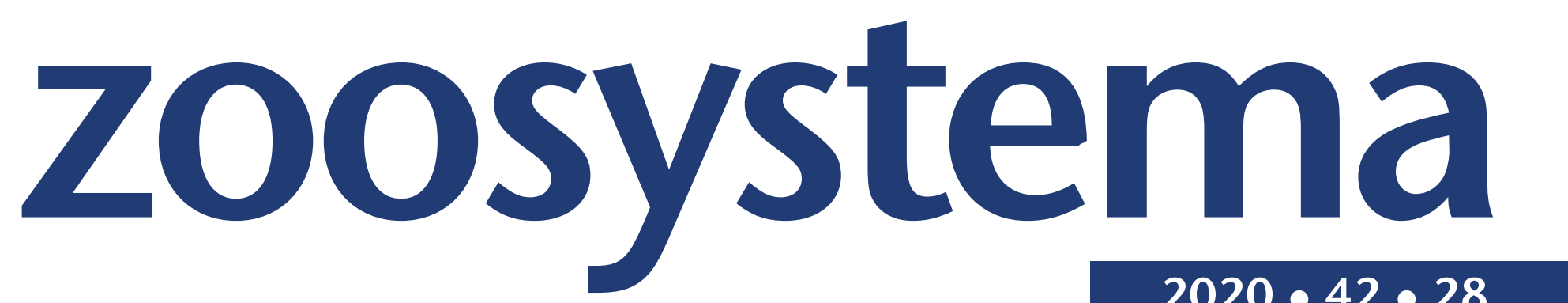

$2020 \bullet 42 \cdot 28$

\%

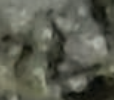

3.

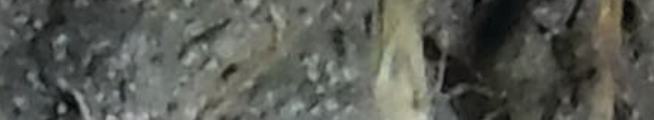

\title{
List of amphibian species
} (Vertebrata, Tetrapoda) of Burkina Faso

Halatuoussa Jöelle AYORO, Gabriel Hoinsoudé SEGNIAGBETO, Emmanuel Midibahaye HEMA, Johannes PENNER, Adama OUEDA, Alain DUBOIS, Mark-Oliver RÖDEL, VI I

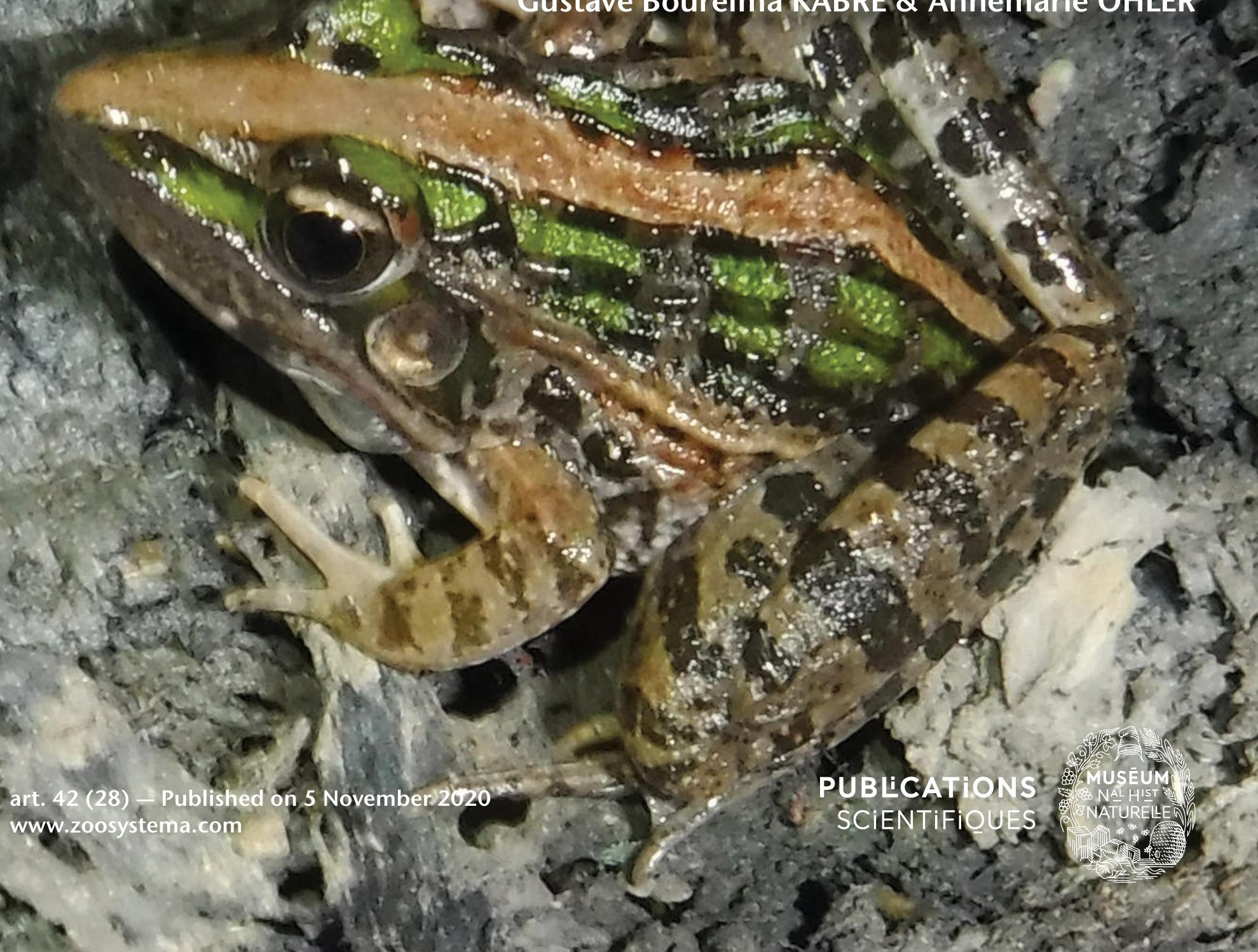


DiRECTEUR de LA PUBLICATION / PUBLICATION DIRECTOR: Bruno David

Président du Muséum national d'Histoire naturelle

RÉDACTRICE EN CHEF / EDITOR-IN-CHIEF: Laure Desutter-Grandcolas

ASSISTANTE DE RÉDACTION / ASSISTANT EDITORS: Anne Mabille (zoosyst@mnhn.fr)

Mise en PAge / Page Layout: Fariza Sissi

COMITÉ SCIENTIFIQUE / SCIENTIFIC BOARD:

James Carpenter (AMNH, New York, États-Unis)

Maria Marta Cigliano (Museo de La Plata, La Plata, Argentine)

Henrik Enghoff (NHMD, Copenhague, Danemark)

Rafael Marquez (CSIC, Madrid, Espagne)

Peter $\mathrm{Ng}$ (University of Singapore)

Jean-Yves Rasplus (INRA, Montferrier-sur-Lez, France)

Jean-François Silvain (IRD, Gif-sur-Yvette, France)

Wanda M. Weiner (Polish Academy of Sciences, Cracovie, Pologne)

John Wenzel (The Ohio State University, Columbus, États-Unis)

COUVERTURE / COVER:

Ptychadena pumilio (Boulenger, 1920). Photo: Halamoussa Joëlle Ayoro.

Zoosystema est indexé dans / Zoosystema is indexed in:

- Science Citation Index Expanded (SciSearch ${ }^{\circledR}$ )

- ISI Alerting Services ${ }^{\circledR}$

- Current Contents ${ }^{\circledR}$ / Agriculture, Biology, and Environmental Sciences ${ }^{\circledR}$

- Scopus ${ }^{\circledR}$

Zoosystema est distribué en version électronique par / Zoosystema is distributed electronically by:

- BioOne ${ }^{\circledR}$ (http://www.bioone.org)

Les articles ainsi que les nouveautés nomenclaturales publiés dans Zoosystema sont référencés par / Articles and nomenclatural novelties published in Zoosystema are referenced by:

- ZooBank ${ }^{\circledR}$ (http://zoobank.org)

Zoosystema est une revue en flux continu publiée par les Publications scientifiques du Muséum, Paris

Zoosystema is a fast track journal published by the Museum Science Press, Paris

Les Publications scientifiques du Muséum publient aussi / The Museum Science Press also publish: Adansonia, Geodiversitas, Anthropozoologica, European Journal of Taxonomy, Naturae, Cryptogamie sous-sections Algologie, Bryologie, Mycologie, Comptes Rendus Palevol

Diffusion - Publications scientifiques Muséum national d'Histoire naturelle

CP $41-57$ rue Cuvier F-75231 Paris cedex 05 (France)

Tél. : 33 (0)1 40794805 / Fax: 33 (0)1 40793840

diff.pub@mnhn.fr / http://sciencepress.mnhn.fr

(C) Publications scientifiques du Muséum national d'Histoire naturelle, Paris, 2020

ISSN (imprimé / print): 1280-9659/ ISSN (électronique / electronic): 1638-9395 


\section{List of amphibian species (Vertebrata, Tetrapoda) of Burkina Faso}

Halamoussa Joëlle AYORO

Laboratoire de Biologie et Ecologie Animales, UFR/SVT, Université Joseph Ki-Zerbo, 3 BP 7021 Ouagadougou 3 (Burkina Faso)

halamoussa.joelle@gmail.com (corresponding author)

Gabriel Hoinsoudé SEGNIAGBETO Laboratoire d'Écologie et d'Écotoxicologie, Faculté des Sciences, Université de Lomé, BP 1515, Lomé (Togo) gsegniagbeto@gmail.com

Emmanuel Midibahaye HEMA Laboratoire de Biologie et Écologie Animales, UFR/SVT, Université Joseph Ki-Zerbo, 3 BP 7021 Ouagadougou 3 (Burkina Faso) hema.emmanuel@yahoo.fr

Johannes PENNER Chair of Wildlife Ecology \& Management, University of Freiburg, Tennenbacher Strasse 4, 79106 Freiburg (Germany) johannes.penner@wildlife.uni-freiburg.de

Adama OUEDA

Laboratoire de Biologie et Écologie Animales, UFR/SVT, Université Joseph Ki-Zerbo, 3 BP 7021 Ouagadougou 3 (Burkina Faso) oueda14@yahoo.fr

Alain DUBOIS

Institut de Systématique, Évolution, Biodiversité (ISYEB) Muséum national d'Histoire naturelle CNRS, Sorbonne Université, EPHE, UA, 57 rue Cuvier, CP 30, F-75005, Paris (France) alain.dubois@mnhn.fr

Mark-Oliver RÖDEL Museum für Naturkunde - Leibniz Institute for Evolution and Biodiversity Science, Invalidenstr. 43, 10115 Berlin (Germany)) Mark-Oliver.Roedel@mfn.berlin

Gustave Boureima KABRÉ Laboratoire de Biologie et Écologie Animales, UFR/SVT, Université Joseph Ki-Zerbo, 3 BP 7021 Ouagadougou 3 (Burkina Faso) gkabre2@gmail.com

Annemarie OHLER Institut de Systématique, Évolution, Biodiversité (ISYEB) Muséum national d'Histoire naturelle CNRS, Sorbonne Université, EPHE, UA, 57 rue Cuvier, CP 30, F-75005, Paris (France) annemarie.ohler@mnhn.fr 
Ayoro H. J., Segniagbeto G. H., Hema E. M., Penner J., Oueda A., Dubois A., Rödel M.-O., Kabré G. B \& Ohler A. 2020. List of amphibian species of Burkina Faso. Zoosystema 42 (28): 547-582. https://doi.org/10.5252/zoosystema2020v42a28. http://zoosystema.com/42/28

\begin{abstract}
We related the first commented list of the amphibian species of Burkina Faso. To obtain contemporary data, we investigated six sites from July 2017 to September 2018. The survey is unique for West Africa in combining a variety of different habitat types, e.g. Sahelian areas, grassland and woodland savannahs, floodplains, gallery forests and agricultural sites. Animals were found at varying spatial scales by opportunistic visual encounter surveys after sunset supplemented with acoustic searching. Further data were based on museum vouchers collected between the years 1959 and 2011 and deposited in European and American museums, and the literature review focusing on the country species. We listed 36 anuran species from 11 families. Surprisingly seven taxa, namely Arthroleptis poecilonotus Peters, 1863, Afrixalus vittiger (Peters, 1876), Afrixalus weidholzi (Mertens, 1938), Kassina cassinoides (Boulenger, 1903), Ptychadena schillukorum (Werner, 1908), Hyperolius lamottei Laurent, 1958 and Amnirana albolabris (west) (Jongsma et al. 2018), were new country records. A few rare, hard to record or little known species, including Arthroleptis poecilonotus, Hyperolius lamottei, Xenopus tropicalis (Gray, 1864) and Amnirana albolabris (west) can be confirmed. The origin of a specimen of Sclerophrys mauritanica (Schlegel, 1841) mentioned as coming from Burkina Faso deposited in the collections of MNHN must be considered as an error. We briefly discussed the taxonomy and indicated the habitats of all species mentioned in this country so far. The discovery of several new country records highlights that the amphibian fauna of Burkina Faso is still incompletely known and that many poorly explored sites may still harbour a high diversity.
\end{abstract}

\title{
RÉSUMÉ
}

Liste des amphibiens (Vertebrata: Tetrapoda) du Burkina Faso.

Nous présentons la première liste commentée des espèces d'amphibiens du Burkina Faso. Nous avons étudié six sites de juillet 2017 à septembre 2018 pour obtenir des données actuelles. Cet échantillonnage est unique en Afrique de l'Ouest par la combinaison de types d'habitats, e.g. zones sahéliennes, savanes herbeuses et boisées, plaines inondables, forêts galeries et zones agricoles. Les amphibiens ont été trouvés à différentes échelles spatiales par des inventaires visuels opportunistes après le coucher du soleil, complétés par une recherche acoustique. Des données supplémentaires ont été fournies par des spécimens présents dans des muséums européens et américains, collectés entre les années 1959 et 2011, et par l'analyse de la littérature consacrée aux espèces du pays. Une liste de 36 espèces appartenant à 11 familles a pu être établie. Il est étonnant de constater que sept espèces sont nouvelles pour le pays, i.e. Arthroleptis poecilonotus Peters, 1863, Afrixalus vittiger (Peters, 1876), Afrixalus weidholzi (Mertens, 1938), Kassina cassinoides (Boulenger, 1903), Ptychadena schillukorum (Werner, 1908), Hyperolius lamottei Laurent, 1958, et Amnirana albolabris (west) (Jongsma et al. 2018). La présence de quelques espèces rares, difficiles à rencontrer ou très peu connues, est confirmée, i.e. Arthroleptis poecilonotus, Hyperolius lamottei, Xenopus tropicalis (Gray, 1864), et Amnirana albolabris (west). L'origine du spécimen de Sclerophrys mauritanica signalé du Burkina Faso dans les collections du MNHN

MOTS CLÉS

Anoures,

diversité,

habitats,

savane,
Sahel,

Afrique de l'Ouest. doit être considérée comme erronée. Nous discutons brièvement la taxonomie de toutes les espèces mentionnées du Burkina Faso jusqu’à présent et indiquons leur habitat respectif. La découverte de plusieurs espèces nouvellement signalées pour le Burkina Faso montre que la faune d'amphibiens de ce pays n'est toujours pas complètement connue et que de nombreux sites peu explorés seraient susceptibles d'héberger une diversité élevée.

\section{INTRODUCTION}

Assessment of biodiversity requires the collaboration with several other disciplines that are involved not only in species protection, but also for sustainable conservation (Thiombiano et al. 2006). In Burkina Faso, since independence in 1960, many areas have been designated as national parks or nature reserves to preserve biodiversity. These areas are the country's ultimate biodiversity protection sites (SP/CONEDD 2010; Kangoyé 2013). In order to preserve and ensure the sustainable management of this bio- diversity, it is important to know more about it, in particular, as natural habitats are increasingly threatened by the expansion of human populations and their activities (Maydell 1983). In addition, this strong environmental disruption is amplified by frequent soil erosion (Cesar $e t a l .2011)$ and changing climate (Kambiré et al. 2015). Because frogs and toads have diphasic life-cycle and semi-permeable skin, they are likely to be more sensitive to habitat disturbances and indicative of local sources of wetland contamination than are most other vertebrates (Wells 2007; Baillie et al. 2010). Amphibians could be the 


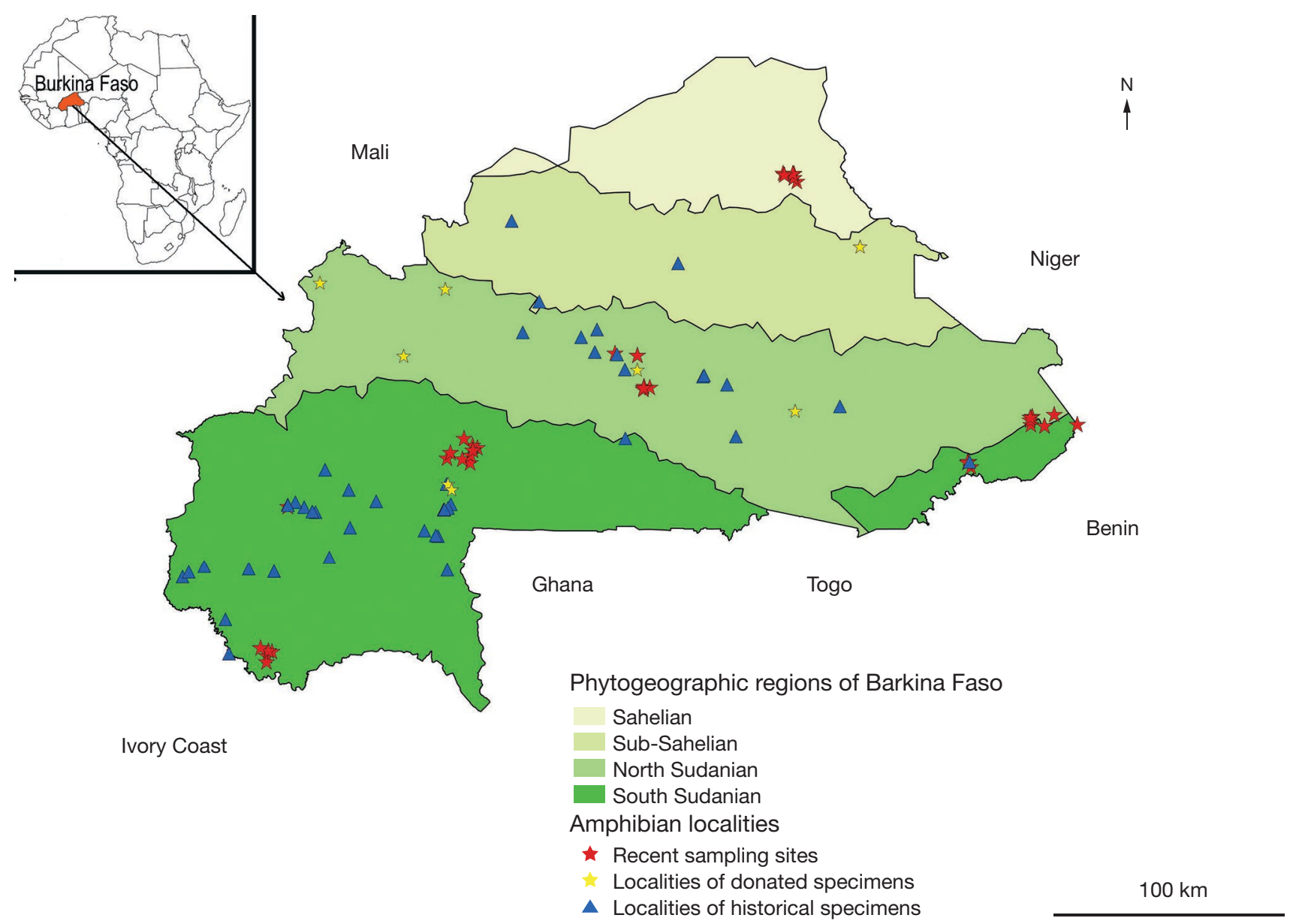

FIG. 1. - Map showing the position of Burkina Faso in Africa (inset figure), and the vegetation zones of Burkina Faso with all localities where amphibian specimens were collected. Source: BNDT (2002).

most affected vertebrates in the context of savannah habitat disturbance because of their limited mobility and high skin permeability. In comparison to other West African countries (Benin, Ivory Coast, Ghana, Guinea, Nigeria, Senegal and Togo), Burkinabe amphibian fauna is poorly studied. However, some authors had reported the presence of amphibian species (Lamotte 1967a; Schiøtz 1967; Lamotte \& Xavier 1981; Böhme et al. 1996; Rödel 2000; Böhme \& Heath 2018). Mohneke et al. (2010a) recently reported 17 species in Burkina Faso. Further data provided by Mohneke (2011) and Mohneke et al. (2011) increased the country checklist up to 25 amphibian species, thus being very low to expected species richness.

The objective of this study was to provide an-updated list of all amphibian species reported and collected in Burkina Faso. We further present specimens examined from some museum collections and literature information.

\section{MATERIAL AND METHODS}

STUDY AREA

Burkina Faso covers an area of $274.200 \mathrm{~km}^{2}$ and is a landlocked Sahelian country situated almost within the heart of West Africa.
It is located between $9.33333^{\circ} \mathrm{S}$ and $15.05000^{\circ} \mathrm{N} ;-5.03000^{\circ} \mathrm{W}$ and $2.33333^{\circ} \mathrm{E}$. Along its northern border, the country is limited by Niger and Mali, while Ivory Coast, Ghana, Togo and Benin limit the southern parts (Dembélé 2010; Fig. 1). The country is characterized by a Sudano-Sahelian climate with two annual seasons: a dry season extending from October to April, followed by a rainy season between May and September. Furthermore, three climatic zones extend from the south to the north: the Sudanese zone (between $10.00000^{\circ} \mathrm{N}$ and $11.50000^{\circ} \mathrm{N}$ ), the Sub-Sahelian zone (between $11.50000^{\circ} \mathrm{N}$ and $14.00000^{\circ} \mathrm{N}$ ) and the Sahelian zone (north of $14.00000^{\circ} \mathrm{N}$ ). The Sudanese zone has an annual rainfall ranging from 900-1200 mm while respective annual rainfalls for the Sub-Sahelian zone and the Sahelian zone are comprised between 600-900 $\mathrm{mm}$ and less than 600 mm (Dembélé 2010; Akoudjin et al. 2016).

The Sahelian vegetation ranges from grassy to wooded savannahs (Ganaba 2008). In the Sudanese zone, forest islets, especially sacred groves can be found within different savannah habitats. The main rivers (Mouhoun, Nakambé, Nazinon, Comoé and Pendjari) are bordered by gallery forests widening towards the South. The country average altitude is $400 \mathrm{~m}$ a.s.l., reaching $125 \mathrm{~m}$ a.s.l. in the South-East (Pama region) and $749 \mathrm{~m}$ a.s.l. in the South-West (Takakourou peak) (MEE 1999). 
TABLE 1. - Summary of recent study sites, giving locality, climatic zones (from south to north, sub-Sudanian, Sudanian, Sahelian), annual amount of rainfall (in $\mathrm{mm}$ ), dominating vegetation in habitat and category of human disturbance (undisturbed/disturbed).

\begin{tabular}{|c|c|c|c|c|c|}
\hline Sites & Coordinates & Climate zone & Rainfall (mm/an) & Vegetation types & Site status \\
\hline \multirow{2}{*}{$\begin{array}{l}\text { Arly and W National } \\
\text { Parks }\end{array}$} & $11.570^{\circ} \mathrm{N}, 1.452^{\circ} \mathrm{E} /$ & Sudanian and & \multirow[t]{2}{*}{$900-1200$} & Trees, shruby and herbaceous & \multirow[t]{2}{*}{ Undisturbed } \\
\hline & $11.887^{\circ} \mathrm{N}, 2.119^{\circ} \mathrm{E}$ & Sub-Sudanian & & savannahs & \\
\hline $\begin{array}{l}\text { Comoé-Léraba } \\
\text { Forest }\end{array}$ & $9.836^{\circ} \mathrm{N},-4.623^{\circ} \mathrm{W}$ & Sub-Sudanian & $900-1200$ & $\begin{array}{l}\text { Trees, shruby and herbaceous } \\
\text { savannahs }\end{array}$ & Undisturbed \\
\hline Kou Forest & $11.189^{\circ} \mathrm{N},-4.439^{\circ} \mathrm{W}$ & Sub-Sudanian & $900-1200$ & Gallery forest and trees savannah & Undisturbed \\
\hline $\begin{array}{l}\text { Deux Balés National } \\
\text { Park }\end{array}$ & $11.677^{\circ} \mathrm{N},-2.836^{\circ} \mathrm{W}$ & Sudanian & $600-900$ & $\begin{array}{l}\text { Trees, shruby and herbaceous } \\
\text { savannahs }\end{array}$ & Undisturbed \\
\hline Pabré & $12.517^{\circ} \mathrm{N},-1.597^{\circ} \mathrm{W}$ & Sudanian & $600-900$ & Herbaceous and shruby savannahs & Disturbed \\
\hline Loumbila & $12.498^{\circ} \mathrm{N},-1.403^{\circ} \mathrm{W}$ & Sudanian & $600-900$ & Herbaceous and shruby savannahs & Disturbed \\
\hline Koubri & $12.229^{\circ} \mathrm{N},-1.345^{\circ} \mathrm{W}$ & Sudanian & $600-900$ & Herbaceous and shruby savannahs & Disturbed \\
\hline Dori & $14.004^{\circ} \mathrm{N},-0.024^{\circ} \mathrm{W}$ & Sahelian & Less than 600 & Herbaceous and shruby steppe & Disturbed \\
\hline Yakouta & $14.075^{\circ} \mathrm{N},-0.143^{\circ} \mathrm{W}$ & Sahelian & Less than 600 & Herbaceous and shruby steppe & Disturbed \\
\hline
\end{tabular}

\section{DATA COLLECTION}

Data for this study stem from three sources: literature review, museum collection and field sampling.

\section{LITERATURE REPORTS}

We searched for scientific articles on internet and consulted books and journals in libraries to extract the respective data. The following papers and books mentioned amphibian species from Burkina Faso: Lamotte (1967a), Schiøtz (1967, 1999), Lamotte \& Xavier (1981), Böhme et al. (1996), Rödel (2000), Mohneke et al. (2010a, 2011), Mohneke (2011) and Böhme \& Heath (2018). Most recently the book by Channing \& Rödel (2019) provided maps for entire Africa, including Burkina Faso.

The species taxonomy was critically revised to be in accordance with the current state of science. We refer to the version 6.1 on 31 October 2020 of the online reference of Frost (2019) for current taxonomy.

\section{EXAMINATION OF MUSEUM COLLECTIONS}

Specimens from the herpetological collections of MNHN (France), ZFMK (Germany), MHNG (Switzerland) and MVZ (USA) were analysed. About 400 museum specimens were studied: 325 from MNHN, 25 from ZFMK, 40 from MHNG and 10 from MVZ.

\section{FIELD SAMPLING}

Field work was conducted to complete our data. Six sites across Burkina Faso were prospected from July 2017 to September 2018, in both rainy and dry seasons. Prospected areas were the National Parks of Arly and W, the Comoé-Léraba Forest, the Kou Forest, the Deux Balés National Park (protected areas), the rural areas of Pabré, Loumbila and Koubri (unprotected areas) and the peri-urban area of Dori-Yakouta (unprotected area) (Table 1). These areas were selected on the basis of vegetation cover and rainfall, the need to present faunal lists for protected areas, or particular gaps in the amphibian data for these parts of the country.

Because of the intense heat during the day, particularly in Sahelian regions, frogs and toads were mostly active after sunset. These animals were hence searched at night between 18.0021.30 GMT. We investigated six general areas, each during seven and ten days, and applied opportunistic visual searches in various habitats such as temporary and permanent ponds, gallery forests, agricultural sites, grasslands and open savannah woodlands (Fig. 2). Systematic visual searches consisted in scraping through leaf litter, lifting rocks and logs, looking around or within burrows and termite mounds. Additional supports of acoustic signals and dip netting for tadpoles were applied (Rödel \& Ernst 2004). Specimens were collected by hand and photographed. We used a hand-held GPS receiver (GPS Garmin etrex-10) to record the geographical positions of all study sites. After capture, scientific name to species or subspecies level, sex, SVL, reproductive condition, date, time and habitat characteristics (presence of water bodies, vegetation type, etc.) were recorded for each specimen. Frogs and toads were measured with dial-calipers (accuracy $\pm 0.1 \mathrm{~mm}$ ) and their SVL were given in $\mathrm{mm}$. Each animal not kept as voucher was released at its site of capture. Voucher specimens were euthanized humanly in a 1,1,1-Trichloro-2-methyl2-propanol hemihydrate (MS222) solution or in a chlorobutanol and thereafter preserved in $70 \%$ ethanol. Tissue samples (muscle or liver) were conserved in $70 \%$ alcohol for future genetic studies.

The specimens were inventoried at the Laboratoire de Biologie et Ecologie Animales of the University of Joseph Ki-Zerbo. Some voucher specimens (158 specimens) and approximately 200 tissue samples were deposited at the MNHN in Paris. Released specimens are listed in the paragraph Field material.

LOCAL TERMS

Bouli, an artificial water body constructed to collect runoff water during the rainy season for animals is generally composed of a supply channel and a protective dike (MERH 2012). In dry season, these boulis obtain water from boreholes. A bouli is also generally deeper than a pond.

\section{ABBREVIATIONS}

Institutions

BNDT Base Nationale de Données Topographiques,
IFS

IPCC

IUCN
Ouagadougou;

International Foundation for Sciences, Stockholm; Intergovernmental Panel on Climate Change, Genève; International Union for Conservation of Nature, Genève; 

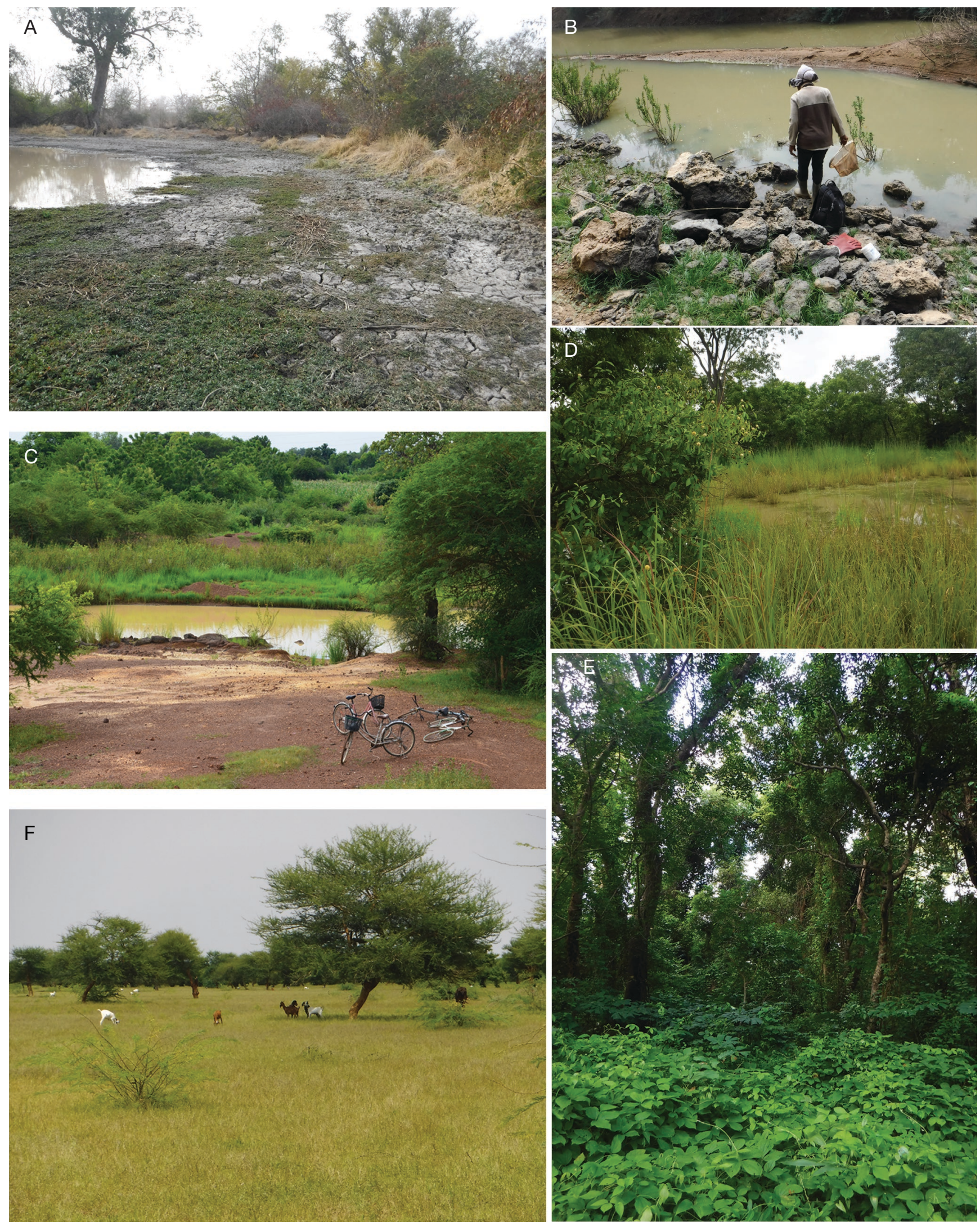

FIG. 2. - Various habitats of amphibian species from Burkina Faso. A, banks of ponds in dry season from W National Park; B, stones on the bank of the Mékrou River in dry season (W National Park); C, shrubby savannah habitats at rainy season from Koubri; $\mathbf{D}$, rainy season shrubby savannah habitats from Comoé-Léraba Forest; E, gallery forest from Kou Forest at Nasso; F, Sahelian swampy valley habitat from Dori (in rainy season). Photos: Halamoussa Joëlle Ayoro. 
MEE Ministère de l'Environnement et de l'Eau, Ouagadougou;

MERH Ministère de l'Environnement et des Ressources Halieutiques, Ouagadougou;

MHNG Muséum d'Histoire naturelle, Genève;

MNHN Muséum national d'Histoire naturelle, Paris;

MVZ Museum of Vertebrate Zoology, Berkeley;

OFINAP Office National des Aires Protégées, Ouagadougou;

SONATUR Société Nationale d'Aménagement des Terrains Urbains, Ouagadougou;

SP/CONEDD Secrétariat Permanent du Conseil National de l'Environnement et du Développement Durable, Ouagadougou;

ZFMK Zoologisches Forschungsinstitut und Museum Alexander Koenig, Bonn;

ZMB Museum für Naturkunde Berlin, Berlin.

\section{Measurement}

SVL Snout-Vent-Length.

\section{RESULTS}

The literature review revealed records for 25 amphibian species in Burkina Faso. The examination of museum vouchers added to a total of 31 species. During the field work, 31 species were recorded. The total number of amphibian species in Burkina Faso with all three data sets was 36 species from 11 families (Table 2). From these 36 species, 31 were confirmed by new records. Five species reported previously were not observed during our field work, i.e. Sclerophrys mauritanica (Schlegel, 1841), Hyperolius lamottei Laurent, 1958, Ptychadena tournieri (Guibé \& Lamotte, 1955), Tomopterna milletihorsini (Angel, 1922) and Amnirana albolabris (west) (Jongsma et al. 2018).

\section{COMMENTED SPECIES LIST}

\section{Family ARTHROLEPTIDAE Mivart, 1869}

Arthroleptis poecilonotus Peters, 1863 (Fig. 3A, B)

COllection MATERIAL. - Burkina Faso • 10 subadults (SVL 12.1$20.1 \mathrm{~mm}$ ); Bobo-Dioulasso, near Nasso; $11.18803^{\circ} \mathrm{N},-4.29741^{\circ} \mathrm{W}$; 420 m a.s.l.; VII.1970; M. Lamotte leg.; MNHN-RA-2008.1055, 2008.1056, 2008.1057, 2008.1058, 2008.1059, 2008.1060, 2008.1061, 2008.1062, 2008.1063, 2008.1064.

FIELD MATERIAL. - Burkina Faso • 2 (SVL 27.6-28.1 mm), 5 ơ (SVL 24.4-26.5 mm), 3 subadults (SVL 16.6-18.3 mm); Nasso, Kou Forest; $11.18888^{\circ} \mathrm{N},-4.43935^{\circ} \mathrm{W} ; 320 \mathrm{~m}$ a.s.l.; 7-9.VIII. 2018; H. J. Ayoro \& A. Ohler leg.; gallery forest; hand capture.

DESCRIPTION. - 20 specimens examined. Small frogs with a blunt snout, short head and a concave tympanum; slender limbs, the inner metatarsal tubercle long and prominent. Adult males and females with protruding palmar and supernumerary tubercles on fingers. Tubercles absent on toes. Dorsum feebly granulated. In life, dorsum grey, brown or reddish-brown coloured. Sometimes an hourglass pattern present on back (Fig. 3A, B). Venter with whitish or brownish, smooth skin. As other Arthroleptis species (e.g. Blackburn 2009; Blackburn et al. 2010), presence of an elongated third finger, and transparent spines on second and third fingers in adult males.
HABITAT. - The historical specimens and the recent samples of A. poecilonotus were from Kou Forest (Fig. 2E). At this site, males were seen at night on leaves of shrub and grass at heights varying from 0.2-1 m. Females and subadults were seen hiding in leaflitter. The species may occur in other gallery forests along the major rivers (Mouhoun, Comoé and Pendjari rivers) in the western and southern part of Burkina Faso as well (Lamotte 1967b). It was found in a forest close to a waterfall near Pendjari National Park in Benin (Nago et al. 2006), in Togo (Segniagbeto et al. 2007), in Ivory Coast (Lamotte \& Perret 1963; Lamotte 1967b; Barbault \& Trefaut-Rodrigues 1979; Rödel 2000; Rödel 2003; Rödel \& Ernst 2003) and in Nigeria (Schiøtz 1964, 1967; Leaché et al. 2006; Onadeko 2016).

TAXONOMIC REMARK. - As stated in Rödel \& Bangoura (2004) and Blackburn (2010), it is currently not possible to assign these West African Arthroleptis taxa with certainty to one of the various available names, as intra-specific variability equals or surpasses interspecific differences. As actually understood, A. poecilonotus has an extended distribution range, including West, Central and parts of East Africa (Frost 2019) and probably recovers a group of species. Type locality is in West Africa, in south-eastern Ghana. Further studies, in particular including topotypical material, are needed for taxonomic decisions.

Leptopelis bufonides Schiøtz, 1967 (Fig. 3C)

FIELD MATERIAL. - Burkina Faso • 8 (SVL 40.2-44.9 mm), $100^{\circ}$ (SVL 30.5-37.5 mm); W National Park; $11.93664^{\circ} \mathrm{N}, 1.9946^{\circ} \mathrm{E}$; $310 \mathrm{~m}$ a.s.l.; 21.VI.2018; H. J. Ayoro leg.; edge of savannah pond; hand capture 1 o (SVL $41.2 \mathrm{~mm}$ ), 1 ơ (SVL $32.1 \mathrm{~mm}$ ); Tuy province, Koti; $11.38785^{\circ} \mathrm{N},-3.06404^{\circ} \mathrm{W} ; 295 \mathrm{~m}$ a.s.l.; 23.VIII.2018; H. J. Ayoro leg. as for preceding; near small pond in bush; hand capture.

Literature REPORTS. - Burkina Faso - Passoré province, Samba; $12.70143^{\circ} \mathrm{N},-2.40389^{\circ} \mathrm{W} ; 300 \mathrm{~m}$ a.s.l.; 18.VIII.1961 (Schiøtz 1967) - Gourma province, Fada N'gourma; $12.06051^{\circ} \mathrm{N}, 0.34913^{\circ} \mathrm{E}$; $300 \mathrm{~m}$ a.s.l. (Mohneke et al. 2011) • Ganzourgou province, Zorgho; $12.2483^{\circ} \mathrm{N},-0.6278^{\circ} \mathrm{W} ; 300 \mathrm{~m}$ a.s.l.; I-III.2008 (Mohneke et al. 2011).

DESCRIPTION. - 20 specimens examined. Leptopelis bufonides with small to moderate size and warty skin, stocky body shape, and short legs. In contrast to most other members of that genus, the fingers with small discs on their tips. In life colouration greyish brown with dark spots, including a dark interorbital spot and elongated spots or bands on the back (Fig. 3C). These markings making almost a " $\mathrm{m}$ " pattern. The venter light to dark grey, with a dark throat in both sexes. For detailed descriptions, see Schiøtz (1967), Rödel (2000) and Amiet (2012).

HABITAT. - This species was usually found in grassy and wooded savannahs (Fig. 2C, D). Specimens were collected from the ground around temporary ponds with grass banks and shrubs. It was also Evans from dry savannahs in Senegal (Schiøtz 1967), Mali (Böhme \& Heath 2018), Ghana (Schiøtz 1967), Benin (Nago et al. 2006), Togo (Segniagbeto et al. 2007) and Cameroon (Amiet 2012).

\section{Leptopelis viridis (Günther, 1869)} (Fig. 3D)

COllection MATERIAL. - Burkina Faso • 2 ㅇ (SVL 38.7-41.7 mm); Kadiogo province, Pabré; $12.51602^{\circ} \mathrm{N},-1.59691^{\circ} \mathrm{W} ; 300 \mathrm{~m}$ a.s.l.; M. Lamotte leg.; MNHN-RA-1999.7060, 1999.7061.

FIELD MATERIAL. - Burkina Faso • $100^{7}$ (SVL 30.5-37.9 mm); Kadiogo province, Pabré dam; $12.51605^{\circ} \mathrm{N},-1.59689^{\circ} \mathrm{W}$; 

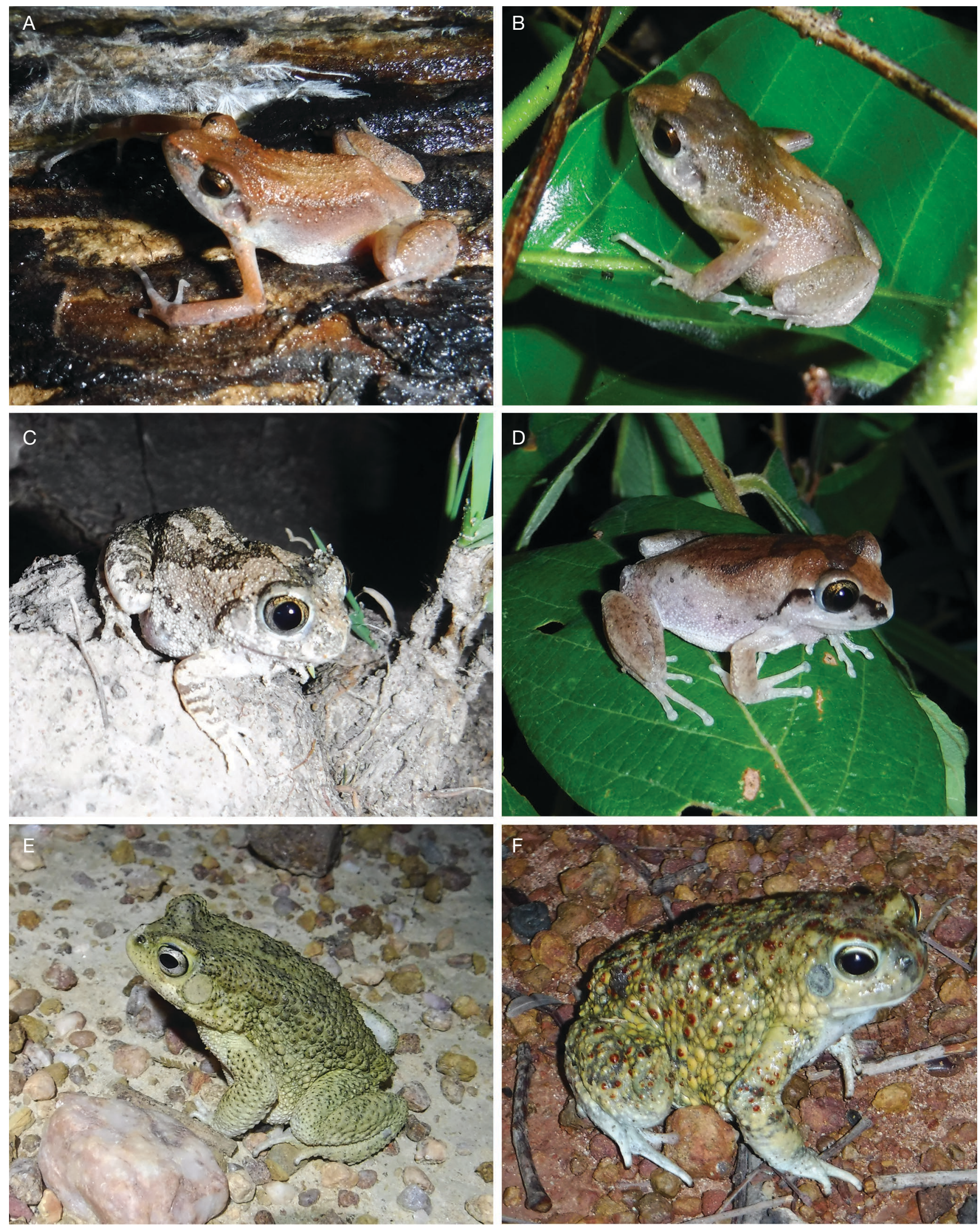

FIG. 3. - Representatives of anuran species from Burkina Faso in life. A-B, Arthroleptis poecilonotus Peters, 1863; C, Leptopelis bufonides Schiøtz, 1967; D, Leptopelis viridi (Günther, 1869); E, Sclerophrys maculata (Hallowell, 1854); F, Sclerophrys pentoni (Anderson, 1893). Photos: Halamoussa Joëlle Ayoro. 
290 m a.s.l.; 12.VII.2017; H. J. Ayoro \& A. Ohler leg.; bank of Pabré dam; hand capture • 3 o $^{7}$ (SVL 36.1-38.7 mm); Oubritenga province, Loumbila dam; $12.49829^{\circ} \mathrm{N},-1.40310^{\circ} \mathrm{W} ; 275 \mathrm{~m}$ a.s.l.; 14.VII.2017; same collectors as for preceding; around a plantain field downstream from the Loumbila dam; hand capture $\bullet 50^{\circ}$ (SVL 32.9-36.1 mm); Koubri, "Ancien barrage"; $12.22883^{\circ} \mathrm{N}$, $-1.34522^{\circ} \mathrm{W} ; 290 \mathrm{~m}$ a.s.l.; 16.VII.2017; same collectors as for preceding; in a maize field on the bank of "Ancien barrage" 1 1 (SVL $54.5 \mathrm{~mm}$ ); Koubri, the inn's court of Monastery; $12.21685^{\circ} \mathrm{N}$, $-1.35041^{\circ} \mathrm{W} ; 285 \mathrm{~m}$ a.s.l.; $17 . V I I .2017$; same collectors as for preceding; under shrubs; hand capture $\bullet 1 \mathrm{O}^{\text {; }}$; Kadiogo province, town hall of Saaba; $12.37209^{\circ} \mathrm{N},-1.40374^{\circ} \mathrm{W} ; 305 \mathrm{~m}$ a.s.l.; 30.VII.2018; H. J. Ayoro leg.; on shrubs near habitations; acoustic recording - $20^{7}$ (SVL 33.9-36.5 mm); Arly National Park, Bouliabou pond; $11.57890^{\circ} \mathrm{N}, 1.46393^{\circ} \mathrm{E} ; 170 \mathrm{~m}$ a.s.l.; 12 .VI.2018; same collector as for preceding; on a shrub; hand capture • $60^{7}$ (SVL 32.2$33.8 \mathrm{~mm}$ ); Arly National Park, Bongola swampy valley; $11.53255^{\circ} \mathrm{N}$, $1.48244^{\circ} \mathrm{E} ; 170 \mathrm{~m}$ a.s.l.; 13.VI.2018; same collector as for preceding; on a shrub; hand capture 3 \% (SVL 39.3-42.3 mm); Arly National Park, a floodplain (500 m north of Bouliabou pond); $11.57852^{\circ} \mathrm{N}, 1.46000^{\circ} \mathrm{E} ; 170 \mathrm{~m}$ a.s.l.; $16 . V I .2018$; same collector as for preceding; on the edge of a small water body; hand capture - 1 ơ (SVL $33.8 \mathrm{~mm}$ ), 2 \% (SVL 45.3-45.7 mm); W National Park, Kabougou River (500 m north-west of Kabougou forest post office); $11.97062^{\circ} \mathrm{N}, 2.01624^{\circ} \mathrm{E} ; 280 \mathrm{~m}$ a.s.l.; 18.VI.2018; same collector as for preceding; on the edge of a pond; hand capture - 1 Ơ $^{7}$ (SVL $34.4 \mathrm{~mm}$ ), 1 ㅇ (SVL $39.8 \mathrm{~mm}$ ); W National Park, Nangouli swampy valley; $11.93663^{\circ} \mathrm{N}, 1.99461^{\circ} \mathrm{E} ; 310 \mathrm{~m}$ a.s.l.; 21.VI.2018; same collector as for preceding; around a small pond; hand capture $110^{\text {; }}$; Deux Balés National Park, downstream from the Soumbou dam; $11.69831^{\circ} \mathrm{N},-2.79705^{\circ} \mathrm{W} ; 260 \mathrm{~m}$ a.s.l.; 8.XI.2017; same collector as for preceding; hand capture $20^{\circ}$ (SVL 30. 8-31.2 mm), 1 \% (SVL $40.1 \mathrm{~mm}$ ); Tuy province, Koti; $11.38783^{\circ} \mathrm{N},-3.06404^{\circ} \mathrm{W} ; 300 \mathrm{~m}$ a.s.l.; 23.VIII.2018; same collector as for preceding; near a maize field; hand capture $\bullet 120^{0}$ (SVL 31.3-36.4 mm), 2 ㅇ (SVL 43.1-43.6 mm); Comoé-Léraba Forest, Baboro swampy valley; $9.92523^{\circ} \mathrm{N},-4.57562^{\circ} \mathrm{W}$ $240 \mathrm{~m}$ a.s.l.; 4.VIII.2018; H. J. Ayoro \& A. Ohler leg.; on shrubs; hand capture $30^{7}$ (SVL 29.5-33.5 mm); Comoé province, bank of Folonzo village pond; $9.95775^{\circ} \mathrm{N},-4.67451^{\circ} \mathrm{W} ; 240 \mathrm{~m}$ a.s.l.; 6.VIII.2018; same collectors as for preceding; on grasses, hand capture • 1 ơ (SVL 35.6 mm), 1 \% (SVL 48.7 mm); Nasso, Kou Forest; $11.18812^{\circ} \mathrm{N},-4.44390^{\circ} \mathrm{W} ; 320 \mathrm{~m}$ a.s.l.; 9.VIII.2018; same collectors as for preceding; near a small water body; hand capture - Ioba province, Bontioli reserve; $10.93685^{\circ} \mathrm{N},-3.13801^{\circ} \mathrm{W}$; $260 \mathrm{~m}$ a.s.l.; 2011; J. Penner leg.; field direct observation.

LiterATURE REPORTS. - Burkina Faso • Passoré province, Yako; $12.96740^{\circ} \mathrm{N},-2.26151^{\circ} \mathrm{W} ; 330 \mathrm{~m}$ a.s.l.; 1961 (Schiøtz 1967; Böhme et al. 1996) • Gourma province, Fada N'gourma; $12.06051^{\circ} \mathrm{N}$ $0.34913^{\circ} \mathrm{E} ; 300 \mathrm{~m}$ a.s.l. (Mohneke 2011; Mohneke et al. 2011) - Ganzourgou province, Zorgho; $12.2483^{\circ} \mathrm{N},-0.6278^{\circ} \mathrm{W} ; 300 \mathrm{~m}$ a.s.l.; I-III.2008 (Mohneke 2011; Mohneke et al. 2011).

DESCRIPTION. - 58 specimens examined. Size of this species 33$35 \mathrm{~mm}$ for males and $42-48 \mathrm{~mm}$ for females, according to Schiøtz (1967; 1999) and Rödel (2000). Size slightly larger in our voucher specimens. Leptopelis with smoother skin, longer extremities and larger discs on toes and fingers (Fig. 3C, D). Dorsal colouration brownish or reddish brown with darker spots forming a mark of the shape of a reversed "V". Venter whitish. juveniles colour mostly green. For detailed descriptions, see Lamotte \& Xavier (1981), Schiøtz (1967, 1999), Rödel (2000) and Amiet (2012).

HABITAT. - The species was fossorial during the day and arboreal at night. Leptopelis viridis was found in herbaceous and wooded savannahs (Fig. 2C, E). Males were caught on trees and shrubs around ponds and rivers at heights varying between $0.5-3 \mathrm{~m}$. In contrast to males, females were collected on the ground of the same habitats.
Family BUFONIDAE Gray, 1825

\section{Sclerophrys maculata (Hallowell, 1854)}

(Fig. 3E)

COLleCtiOn MATERIAL. - Burkina Faso • $50^{\circ}$ (SVL 42.0-49.6 mm), 1 ㅇ (SVL 53.2 mm); Burkina Faso; 1987; M. Lamotte leg.; MNHNRA-1944.143, 1951.255, 1989.3863, 1989.3864, 1989.3865, 1989.3866.

FIELD MATERIAL. - Burkina Faso • 1 9 (SVL 70.7 mm); Arly National Park, the court of the central forest post office; $11.57044^{\circ} \mathrm{N}$, $1.45215^{\circ} \mathrm{E} ; 190 \mathrm{~m}$ a.s.l.; 11.VI.2018; H. J. Ayoro leg.; on a path; hand capture • $1 \mathrm{O}^{7}$ (SVL $55.8 \mathrm{~mm}$ ), 1 \% (SVL $65.9 \mathrm{~mm}$ ); Arly National Park, Bongola swampy valley; $11.53255^{\circ} \mathrm{N}, 1.48242^{\circ} \mathrm{E}$; $170 \mathrm{~m}$ a.s.l.; 13.VI.2018; same collector as for preceding; on the edge of pond; hand capture $1 \mathrm{o}^{7}$ (SVL $\left.54.2 \mathrm{~mm}\right), 4$ (62.4-66.3 mm); Arly National Park, on the bank of Arly River $(1.5 \mathrm{~km}$ west of the central forest post office); $11.57043^{\circ} \mathrm{N}, 1.45222^{\circ} \mathrm{E} ; 160 \mathrm{~m}$ a.s.l.; 14.VI.2018; same collector as for preceding, near a small water body; hand capture • $10^{\pi}$ (SVL $\left.56.0 \mathrm{~mm}\right), 1$ ㅇ (SVL $65.2 \mathrm{~mm}$ ); Arly National Park, a floodplain (500 m north of Bouliabou pond); $11.57854^{\circ} \mathrm{N}, 1.46001^{\circ} \mathrm{E} ; 260 \mathrm{~m}$ a.s.l.; 16.VI.2018; same collector as for preceding; near a small water body; hand capture $110^{7}$ (SVL $54.3 \mathrm{~mm}$ ); Arly National Park, central forest post office; $11.57843^{\circ} \mathrm{N}, 1.46145^{\circ} \mathrm{E} ; 170 \mathrm{~m}$ a.s.l.; $17 . V I .2018$; same collector as for preceding; under a dead wood; hand capture $110^{7}$ (SVL 75.8 mm); W National Park, Kabougou River $(500$ m north-west of the Kabougou forest post office); $11.97063^{\circ} \mathrm{N}, 2.01620^{\circ} \mathrm{E} ; 280 \mathrm{~m}$ a.s.l.; 4.II.2017; same collector as for preceding; in the water well; hand capture • $60^{7}$ (SVL 52.6-79.4 mm), 1 क (SVL $76.6 \mathrm{~mm}$ ); same locality; 18.VI.2018; same collector as for preceding; in a paddy field; hand capture $11 \mathrm{O}^{\text {" }}$ (SVL $75.5 \mathrm{~mm}$ ); W National Park, Nangouli swampy valley; 21.VI.2018; same collector as for preceding; under shrubs; hand capture $30^{7}$ (SVL 56.4-64.2 mm), 3 9 (SVL 56.9$73.8 \mathrm{~mm}$ ); Comoé-Léraba Forest, a flooded zone of the Comoé River ( $300 \mathrm{~m}$ west of Comoé bridge); $9.93243^{\circ} \mathrm{N},-4.60651^{\circ} \mathrm{W}$; 220 m a.s.l.; 5.VIII.2018; H. J. Ayoro \& A. Ohler leg.; river bank; hand capture 4 o' (SVL 61.6-82.9 mm), 1 우 (SVL $72 \mathrm{~mm})$; Folonzo village; $9.95773^{\circ} \mathrm{N},-4.67450^{\circ} \mathrm{W} ; 240 \mathrm{~m}$ a.s.l.; 6.VIII.2018; same collectors as for preceding; around a drinking water well; hand capture 1 subadult (SVL 38.2 mm); Kou Forest; 8.VIII.2018; same collectors as for preceding; on a track, hand capture $\bullet 1$ subadult (SVL $38.0 \mathrm{~mm}$ ); Deux Balés National Park, downstream from the Soumbou dam; $11.69835^{\circ} \mathrm{N},-2.79711^{\circ} \mathrm{W} ; 260 \mathrm{~m}$ a.s.l.; 8.XI.2017; H. J. Ayoro leg.; on a stone; hand capture $22 \mathrm{O}^{\prime \prime}$ (SVL 56.7-60.5 mm), 3 † (SVL 66.6-72.6 mm); Deux Balés National Park, Tiona pond; $11.63244^{\circ} \mathrm{N},-2.85431^{\circ} \mathrm{W} ; 270 \mathrm{~m}$ a.s.l.; 9.XI.2017; same collector as for preceding; on the edge of the pond; hand capture $20^{\prime \prime}$ (56.7-64.8 mm); Pabré, on the bank of Pabré dam; 10.VII.2017; H. J. Ayoro \& A. Ohler leg.; near the irrigated ditch; hand capture - $20^{\prime \prime}$ (SVL 63.1-72.2 mm); Loumbila, downstream from the Loumbila dam; 14.VII.2017; $12.49843^{\circ} \mathrm{N},-1.40311^{\circ} \mathrm{W} ; 280 \mathrm{~m}$ a.s.l.; same collectors as for preceding; near a plantain field; hand capture $20 \mathrm{O}^{\text {" }}$ (SVL 61.5-70.2 mm); same locality; 15.VII.2017; same collectors as for preceding; near an irrigation well in a vegetable garden; hand

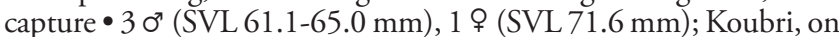
the bank of "Ancien barrage"; $12.22882^{\circ} \mathrm{N},-1.34524^{\circ} \mathrm{W} ; 290 \mathrm{~m}$ a.s.l.; 16.VII.2017; same collectors as for preceding; around water body; hand capture $10^{7}$ (SVL $63.6 \mathrm{~mm}$ ), 1 \% (SVL 67.1 mm); Koubri, downstream from Arzoumbaongo dam; $12.22064^{\circ} \mathrm{N},-1.29590^{\circ} \mathrm{W}$; $270 \mathrm{~m}$ a.s.l.; 18.VII.2017; same collectors as for preceding; near water body; hand capture 1 \% (SVL $51.0 \mathrm{~mm}$ ); Koti; $11.38785^{\circ} \mathrm{N}$, $-3.06401^{\circ} \mathrm{W} ; 310 \mathrm{~m}$ a.s.l.; 17.VIII.2018; H. J. Ayoro leg.; in a maize field; hand capture $1 \mathrm{O}^{\circ}$ (SVL $\left.59.5 \mathrm{~mm}\right)$; Dédougou; $12.49201^{\circ} \mathrm{N}$, $-3.43573^{\circ} \mathrm{W} ; 300 \mathrm{~m}$ a.s.1.; 6.X.2017; same collector as for preceding; under a rock; hand capture $3 \mathrm{O}^{7}$ (SVL 73.3-78.5 mm); Yakouta dam; $14.07452^{\circ} \mathrm{N},-0.14271^{\circ} \mathrm{W} ; 280 \mathrm{~m}$ a.s.l.; 26.VIII.2018; same 
collector as for preceding; near small water body downstream from the dam; hand capture $\bullet 2 \mathrm{O}^{\prime}$; Djibasso, swampy valley; $13.12211^{\circ} \mathrm{N}$, $-4.16030^{\circ} \mathrm{W} ; 340 \mathrm{~m}$ a.sl.; 16.VIII.2018; same collector as for preceding; near a pond; acoustic report.

Literature REPORTS. - Burkina Faso • Gourma province, Fada $\mathrm{N}^{\prime}$ gourma; $12.06051^{\circ} \mathrm{N}, 0.34913^{\circ} \mathrm{E} ; 300 \mathrm{~m}$ a.s.l. (Mohneke 2011; Mohneke et al. 2011) • Ganzourgou province, Zorgho; $12.2483^{\circ} \mathrm{N}$, $-0.6278^{\circ} \mathrm{W} ; 300 \mathrm{~m}$ a.s.l.; I-III.2008 (Mohneke 2011; Mohneke et al. 2011).

DESCRIPTION. - 62 specimens examined. Studied males showing SVL larger than male specimens of Lamotte \& Xavier (1981) (38$54 \mathrm{~mm}$ males, 53-70 mm females). Specimens with warty, flat and poorly delimited parotoid glands (but well delimited and usually elevated glands in $S$. regularis) (Fig. 3E). Supernumerary tubercles on feet more numerous in $S$. maculata than in $S$. regularis (see figures 27 and 33 in Rödel (2000) and figure 4 in Gongomin et al. (2019).

HabitAT. - This toad occurs in many localities across Burkina Faso. We found it around water bodies, in open areas, under grasses or shrubs, in pristine regions as well as in human settlements. It occurs in dry and wet savannahs across western Africa and even penetrates disturbed rainforest habitats (Rödel 2000; Poynton et al. 2016). Populations previously attributed to $S$. maculata from more eastern and southern origins belong to Sclerophrys pusilla (Mertens, 1937) (Poynton et al. 2016). However, the eastern and southern limits of the distribution range of Sclerophry maculata need to be confirmed (Channing \& Rödel 2019).

REMARK. - Sclerophrys maculata was most often cited under the old generic name Bufo, later allocated to the genus Amietophrynus (Frost et al. 2006). This toad was also mistakenly cited from Burkina Faso as Bufo regularis (Reuss, 1833) (e.g. Mohneke 2011). Due to nomenclatural priority, the valid name of this species is actually Sclerophrys maculata (Ohler \& Dubois 2016).

\section{Sclerophrys pentoni (Anderson, 1893)}

$$
\text { (Fig. 3F) }
$$

COLLECTION MATERIAL. - Burkina Faso • 20 9 (SVL 56.6-66.2 mm); Bougouriba province, Diébougou; $10.98411^{\circ} \mathrm{N},-3.25603^{\circ} \mathrm{W}$; 300 m a.s.l.; 3.VI.1976; NA leg.; MHNG 1537.14-33 .

FIELD MATERIAL. - Burkina Faso • $5 \mathrm{o}^{7}$ (SVL 48.1-56.6 mm); Arly National Park, near the flood plain; $11.57853^{\circ} \mathrm{N}, 1.46001^{\circ} \mathrm{E}$; $260 \mathrm{~m}$ a.s.l.; 16.VI.2018; H. J. Ayoro leg.; around a small water body on a trail; hand capture $\bullet 60^{7}$ (SVL 58.2-64.8 mm), 1 \% (SVL 73.2 mm); W National Park, 50 m of the back of the Kabougou forest post office; $11.95738^{\circ} \mathrm{N}, 2.01381^{\circ} \mathrm{E} ; 290 \mathrm{~m}$ a.s.l.; 20.VI.2018; same collector as for preceding; in a small water body on a trail; hand capture 1 subadult (SVL $37.8 \mathrm{~mm}$ ); Comoé-Léraba Forest, $50 \mathrm{~m}$ of the forest; $9.93240^{\circ} \mathrm{N},-4.60655^{\circ} \mathrm{W} ; 220 \mathrm{~m}$ a.s.l.; 5.VIII. 2018 ; H. J. Ayoro \& A. Ohler leg.; on the edge of a maize field; hand capture 1 subadult (SVL $29.3 \mathrm{~mm}$ ); Yakouta, downstream from Yakouta dam; $14.07451^{\circ} \mathrm{N},-0.14290^{\circ} \mathrm{W} ; 280 \mathrm{~m}$ a.s.l.; 26.VIII.2018; H. J. Ayoro leg.; near a sand heap; hand capture $\bullet 60^{\circ}$ (SVL 56$761.8 \mathrm{~mm}$ ), 1 ( (SVL $66.1 \mathrm{~mm}$ ), 1 subadult (SVL $36.4 \mathrm{~mm}$ ); Koti; 23.VIII.2018; same collector as for preceding; near a pond in bush; hand capture 11 individual; Pabré; "Hotel Repère"; $12.51152^{\circ} \mathrm{N}$, $-1.59116^{\circ} \mathrm{W} ; 300 \mathrm{~m}$ a.s.l.; 11.VII.2017; H. J. Ayoro \& A. Ohler leg.; in a swimming pool; field direct observation.

Literature REPORTS. - Burkina Faso • Passoré province, Samba; $12.70143^{\circ} \mathrm{N},-2.40389^{\circ} \mathrm{W} ; 300$ m a.s.l.; 18. VIII. 1961 (Schiøtz 1967) - Yako; $12.96740^{\circ} \mathrm{N},-2.26151^{\circ} \mathrm{W} ; 330 \mathrm{~m}$ a.s.l.; (Schiøtz 1967; Böhme et al. 1996) • Gourma province, Fada N'gourma; $12.06051^{\circ} \mathrm{N}$, $0.34913^{\circ} \mathrm{E} ; 300 \mathrm{~m}$ a.s.l. (Mohneke 2011; Mohneke et al. 2011)
- Ganzourgou province, Zorgho; $12.2483^{\circ} \mathrm{N},-0.6278^{\circ} \mathrm{W} ; 300 \mathrm{~m}$ a.s.l.; I-III.2008 (Mohneke 2011; Mohneke et al. 2011).

DESCRIPTION. - 42 specimens examined. Toad with a broad and round head, a very short snout, and very well delimited, broad parotid glands, especially in females. Limbs relatively shorter than in $S$. maculata and $S$. regularis. Presence of projecting round granules in the dorsal part in all specimens. Dominant colour brownish to dark beige. Dorsal glands or granules reddish (Fig. 3F). The back of the twenty females from MHNG very dark brown or black in alcohol. The venter whitish with a light brown throat.

HAвітAт. - Sclerophrys pentoni was found in many savannah and Sahelian habitats in Burkina Faso (Fig. 2). We collected it in protected areas (Arly National Park, W National Park) and in disturbed zones (near a maize field in Comoé-Léraba and near a farmbush in Koti). It was also found in neighbouring countries, namely Benin (Nago et al. 2006) and Togo (Segniagbeto et al. 2007). Beside, the species was reported from the Sahel and Sahelian savannah of western and eastern parts of Africa (Padial \& De La Riva 2004; Padial et al. 2013; Portik \& Papenfuss 2015; Sow et al. 2017).

\section{Sclerophrys regularis (Reuss, 1833)}

COLLECTION MATERIAL. - Burkina Faso • 6 9 (SVL 57.8-72.2 mm); Burkina Faso; XII.1959; J. Arnoult leg.; MNHN-RA-1970.646, 1970.647, 1970.648, 1970.649, 1970.650, 1970.651 • 4 subadults (SVL 57.4-61 mm); Houet province, Bobo-Dioulasso; $11.18801^{\circ} \mathrm{N},-4.29743^{\circ} \mathrm{W} ; 420 \mathrm{~m}$ a.s.l.; XI.1969; M. Lamotte leg.; MNHN-RA-1995.4358, 1995.4367, 1995.4367, 1995.4373 - 16 ㅇ (SVL 62.1-73.2 mm); Bobo-Dioulasso, Koro; $11.14430^{\circ} \mathrm{N}$, $-4.19881^{\circ} \mathrm{W} ; 350 \mathrm{~m}$ a.s.l.; 30.X.1970; M. Lamotte leg.; MNHNRA-1995.4355, 1995.4356, 1995.4357, 1995.4358, 1995.4359, 1995.4360, 1995.4361, 1995.4362, 1995.4363, 1995.4364, $1995.4365,1995.4366,1995.4369,1995.4370,1995.4371$, 1995.4372 - 1 \% (SVL $89.1 \mathrm{~mm}$ ); Boulgou province, Garango; $11.79981^{\circ} \mathrm{N},-0.55054^{\circ} \mathrm{W} ; 280 \mathrm{~m}$ a.s.l.); 18.VI.1962; M. Lamotte leg.; MNHN-RA-1979.336• 4 subadults (SVL $42-55.1 \mathrm{~mm}$ ); Burkina Faso; 1987; M. Lamotte leg.; MNHN-RA-1989.3863, 1989.3864, 1989.3865, $1989.3866 \bullet 1 \%$ (SVL $66.2 \mathrm{~mm}$ ), 1 subadult (SVL $50.5 \mathrm{~mm}$ ); Comoé province, Tiéfora; $10.62765^{\circ} \mathrm{N},-4.55773^{\circ} \mathrm{W}$; 290 m a.s.l.; 1987; Harald Schreiber leg.; ZFMK 93968-69 • $10^{7}$ (SVL $64.5 \mathrm{~mm}$ ), 6 ㅇ (SVL 74.1-82.3 mm); Kadiogo province, Ouagadougou; $12.38011^{\circ} \mathrm{N},-1.51105^{\circ} \mathrm{W} ; 300 \mathrm{~m}$ a.s.l.;V.1975; NA leg.; MHNG 1537.7-13.

FIELD MATERIAL. - Burkina Faso • $60^{7}$ (SVL 77.0-92.0 mm), 19 (SVL 95.7 mm); Pabré dam; 11-12.VII.2017; H. J. Ayoro \& A. Ohler leg.; around an irrigation ditch; hand capture $\bullet 20^{7}$ (SVL 62.5 $72.2 \mathrm{~mm}$ ), Loumbila, south-west of Loumbila dam; 13.VII.2017; same collectors as for preceding; near a water body; hand capture - 1 ㅇ (SVL 110.9 mm); Koubri, "Ancien barrage"; 16.VII.2017; same collectors as for preceding; on a trail near a small water body; hand capture • 1 o" (SVL 64.4 mm), 2 ㅇ (SVL 66.6-88.5 mm); Kadiogo province, Saaba; 13.X.2017; H. J. Ayoro leg.; under the dustbin; hand capture 1 ơ (SVL 64.6 mm); Deux Balés National Park, Soumbou dam; 8.XI.2017; same collector as for preceding; on a lateritic rock near a water body; hand capture • 2 \% (SVL 60.1-74.6 mm); Deux Balés National Park, a flooded zone of Mouhoun River; 10.XI.2017; same collector as for preceding; on the edge of small pond; hand capture • 5 9 (SVL 59.8-86.4 mm); Koti, backwater; 23.X.2017; same collector as for preceding; on the edge of water well; hand capture - 1 subadult (SVL $49.7 \mathrm{~mm}$ ); Koti; 17.VIII.2018; same collector as for preceding; on a trail; hand capture $\bullet 1$ ᄋ (SVL $82.2 \mathrm{~mm})$; Arly National Park, Bouliabou pond; 16.VI.2018; same collector as for preceding; near water body; hand capture • 2 9 (SVL 69.6$81.0 \mathrm{~mm}$ ); Kou Forest; 8.VIII.2018; H. J. Ayoro \& A. Ohler leg.; under shrubs; hand capture 1 \& (SVL $91.2 \mathrm{~mm}$ ); Dori, Toroodi 
swampy valley; 24.VIII.2018; H. J. Ayoro leg.; near the tarmac road; hand capture 1 \% (SVL $68.9 \mathrm{~mm}$ ); Yaga province, Sebba; 9.VII.2017; A. Antarou leg.; hand capture • 1 \% (SVL $75.1 \mathrm{~mm}$ ); same locality; 21.IX.2018; same collector as for preceding; hand capture $-20^{7}$; Dédougou, SONATUR city (the road from Dédougou to Toughan); 22.VIII.2017; H. J. Ayoro leg.; in a gutter; direct observation 1 ㅇ (SVL $80.7 \mathrm{~mm})$; Sourou province, Toughan; 28.VI.2017; R. Dembélé leg.; hand capture.

Literature REPORTS. - Burkina Faso • Gourma province, Fada $\mathrm{N}^{\prime}$ gourma; $12.06051^{\circ} \mathrm{N}, 0.34913^{\circ} \mathrm{E} ; 300 \mathrm{~m}$ a.s.l. (Mohneke 2011; Mohneke et al. 2011) • Ganzourgou province, Zorgho; $12.2483^{\circ} \mathrm{N}$, $-0.6278^{\circ} \mathrm{W} ; 300 \mathrm{~m}$ a.s.l.; I-III.2008 (Mohneke 2011; Mohneke et al. 2011)

DESCRIPTION. - 69 specimens examined. Male body size from 59.0-90.9 mm while female SVL between 57.4-95.7 mm. Sclerophrys regularis, the largest toads in Burkina Faso with long and smooth parotid glands. For detailed descriptions see Lamotte \& Xavier (1981) and Rödel (2000).

HABITAT. - This is a common species and it is found in numerous habitats, ranging from protected areas, to agricultural and irrigated land and even urban areas in Burkina Faso.

\section{Sclerophrys xeros}

(Tandy, Tandy, Keith \& Duff-MacKay, 1976)

COLlection MATERIAL. - Burkina Faso • 2 \% (SVL 63.8-65.8 mm) $2 \mathrm{o}^{7}$ (SVL 59.3-66.9 mm); Passoré province, Samba; $12.70141^{\circ} \mathrm{N}$, $-2.40390^{\circ} \mathrm{W} ; 300 \mathrm{~m}$ a.s.l.; 10.VII.1961; M. Lamotte leg.; MNHN RA-1979.643, 1979.645, 1979.644, 1979.646 • 2 \% (SVL 64.7$79.6 \mathrm{~mm}$ ), $3 \mathrm{O}^{7}$ (SVL $\left.60.5-68.9 \mathrm{~mm}\right)$; Ouagadougou; $12.38011^{\circ} \mathrm{N}$ $-1.51100^{\circ} \mathrm{W} ; 300 \mathrm{~m}$ a.s.l.;V.1975; M. Lamotte leg.; MHNG 1537.1-5 - 3 ơ $^{7}$ (SVL 69.9-73.7 mm), 4 ㅇ (SVL 78.1-81.1 mm), 1 subadult (SVL $38.5 \mathrm{~mm}$ ); Bougouriba province, Diébougou; $10.98411^{\circ} \mathrm{N}$, -3.25603ํㅏ 300 m a.s.l.;V.1976; NA leg.; MHNG 1536.89-96.

FIELD MATERIAL. - Burkina Faso • 3 9 (SVL 66.0-74.1 mm); Deux Balés National Park, Tiona pond; $11.63245^{\circ} \mathrm{N},-2.85431^{\circ} \mathrm{W}$; $270 \mathrm{~m}$ a.s.l.; 9.XI.2017; H. J. Ayoro leg.; edge of the pond; hand capture $110^{\circ}$ (SVL $\left.77.4 \mathrm{~mm}\right)$; Saaba; $12.37210^{\circ} \mathrm{N},-1.40372^{\circ} \mathrm{W}$ $300 \mathrm{~m}$ a.s.l.; 4.IX.2017; same collector as for preceding; in a small water body near a rubbish dump • 5 \% (SVL 58.1-68.3 mm); Djibasso; $13.12511^{\circ} \mathrm{N},-4.16030^{\circ} \mathrm{W} ; 340 \mathrm{~m}$ a.s.l.; 30.IX.2017; same collector as for preceding; under a light hunting insects; hand capture • 2 \% (SVL 60.1-65.1 mm); same locality; 5.X.2017; same collector as for preceding; under a cattle hay; hand capture - 7 o $^{7}$ (SVL 71.8-85.3 mm), 1 ㅇ (SVL $78.1 \mathrm{~mm}$ ); W National Park, Kabougou village swampy valley (3 km north-west of the Kabougou forest post office); $11.96073^{\circ} \mathrm{N}, 1.99745^{\circ} \mathrm{E} ; 280 \mathrm{~m}$ a.s.l.; 22.VI.2018; same collector as for preceding; in a millet field; hand capture 10 \% (SVL 51.5-84.5 mm); N'Djomga village pond (on the way from Dori to Gorom-Gorom); $14.07222^{\circ} \mathrm{N},-0.04865^{\circ} \mathrm{W}$ $270 \mathrm{~m}$ a.s.l.; 25.VIII.2018; same collector as for preceding; close to a millet field; hand capture 2 \% (SVL 64.7-68.7 mm); Yakouta, downstream from the Yakouta dam; $14.07450^{\circ} \mathrm{N},-0.14291^{\circ} \mathrm{W}$ $280 \mathrm{~m}$ a.s.l.; 26.VIII.2018; same collector as for preceding; under shrubs; hand capture $11 \mathrm{O}^{\prime \prime}$ (SVL $78.8 \mathrm{~mm}$ ); Sebba; $13.43904^{\circ} \mathrm{N}$, $0.52340^{\circ} \mathrm{E} ; 250 \mathrm{~m}$ a.s.l.; 22.IX.2018; A. Antarou leg.; hand capture $20^{\top}$; Dédougou, SONATUR city; $12.48972^{\circ} \mathrm{N}, 3.43611^{\circ} \mathrm{W}$; $300 \mathrm{~m}$ a.s.l.; 23.VIII.2017; H. J. Ayoro leg.; in a drain; visual and acoustic report $10^{7}$; Arly National Park, Bongola swampy valley; $11.53252^{\circ} \mathrm{N}, 1.48245^{\circ} \mathrm{E} ; 170 \mathrm{~m}$ a.s.l.; 13.VI.2018; same collector as for preceding; acoustic report $\bullet 10^{7}$; Arly National Park, near Bouliabou pond; $11.57888^{\circ} \mathrm{N}, 1.46390^{\circ} \mathrm{E} ; 170 \mathrm{~m}$ a.s.l.; 16.VI.2018; same collector as for preceding; acoustic report $\bullet 20^{7}$; Folonzo village swampy valley; $9.95768^{\circ} \mathrm{N},-4.67454^{\circ} \mathrm{W} ; 240 \mathrm{~m}$ a.s.l.; 6.VIII.2018;
H. J. Ayoro \& A. Ohler leg.; acoustic report $110^{\text {; }}$; Kou River savannah; $11.18814^{\circ} \mathrm{N},-4.44397^{\circ} \mathrm{W} ; 375 \mathrm{~m}$ a.s.l.; 9.VIII.2018; same collectors as for preceding; acoustic report.

Literature REPORTS. - Burkina Faso • Gourma province, Fada $\mathrm{N}^{\prime}$ Gourma; $12.06051^{\circ} \mathrm{N}, 0.34913^{\circ} \mathrm{E} ; 300 \mathrm{~m}$ a.s.l.; IX.-XII.2004 (Brito et al. 2008) • Fada N'gourma; $12.06051^{\circ} \mathrm{N}, 0.34913^{\circ} \mathrm{E}$; $300 \mathrm{~m}$ a.s.l. (Mohneke 2011; Mohneke et al. 2011) • Ganzourgou province, Zorgho; $12.2483^{\circ} \mathrm{N},-0.6278^{\circ} \mathrm{W} ; 300 \mathrm{~m}$ a.s.l.; I-III.2008 (Mohneke 2011; Mohneke et al. 2011).

DESCRIPTION. - 49 specimens examined. Toad, similar to $S$. maculata and $S$. regularis, but skin with very prominent warts bearing spinules, more pointed than those of the two other species. Red pattern on the rear parts of thighs (absent in three other Sclerophrys species) and smooth, kidney shaped parotid glands allowing easy identification in the field. For more information on $S$. xeros, see Tandy et al. (1976), Lamotte \& Xavier (1981), Salvador (1996) and Rödel (2000).

HABITAT. - This species was generally recorded from disturbed areas, around water bodies and open wetter habitats. It was sometimes seen inside protected areas. The recent samples were generally from paddy fields and around village ponds. Lanza (1981) and Salvador (1996) reported S. xeros from dry savannahs and very arid zones, at the vicinity of dry rivers, oasis and cattle troughs.

\section{Family DiCROGLOSSIDAe Dubois, 1987}

\section{Hoplobatrachus occipitalis (Günther, 1858)}

COLLECTION MATERIAL. - Burkina Faso • 11 (SVL 62.3-106.7 mm), 6 o $^{7}$ (SVL 69.6-85.8 mm), 6 juveniles (SVL 21.7-47.1 mm); Passoré province, Samba; $12.70142^{\circ} \mathrm{N},-2.40390^{\circ} \mathrm{W} ; 300 \mathrm{~m}$ a.s.l.; 18.VI.1962; M. Lamotte leg.; MNHN-RA-1979.1192, 1979.1193, 1979.1194, 1979.1200, 1979.1203, 1979.1204, 1979.1205, 1979.1207, 1979.1208, 1979.1209, 1979.1210, 1979.1211, 1979.1212, 1979.1213, 1979.1214, 1979.1215, 1979.1216, 1979.1217, 1979.1218, 1979.1219, 1979.1220, 1979.1221, 1979.1222 • 2 우 (SVL 75.7-86.2 mm), 1 ơ (SVL $82.6 \mathrm{~mm}$ ); Ouagadougou; $12.38014^{\circ} \mathrm{N},-1.51104^{\circ} \mathrm{W} ; 300 \mathrm{~m}$ a.s.l.; 1987 ; M. Lamotte leg.; MNHN-RA-1990.4366, 1990.4367, 1990.4368 - 2 ㅇ (SVL 65.7-73.4 mm); Comoé province, Tiéfora; $10.62763^{\circ} \mathrm{N}$, $-4.55772^{\circ} \mathrm{W} ; 290 \mathrm{~m}$ a.s.l.; II.1983; NA leg.; ZFMK 93958, 93967 - $20^{\circ}$ (SVL 56.5-68.9 mm); Comoé province, Dérégoué; $10.75013^{\circ} \mathrm{N}$, $-4.07932^{\circ} \mathrm{W} ; 320 \mathrm{~m}$ a.s.l.; II.1982; NA leg.; ZFMK 38698-99.

Field MATERIAL. - Burkina Faso • 1 9 (SVL 77.6 mm); Loumbila, south-west part of Loumbila dam; $12.49844^{\circ} \mathrm{N},-1.40313^{\circ} \mathrm{W}$; $280 \mathrm{~m}$ a.s.l; 13.VII.2017; H. J. Ayoro \& A. Ohler leg.; around a water body; hand capture 1 \% (SVL $105.8 \mathrm{~mm}$ ); downstream from the Loumbila dam; $12.49844^{\circ} \mathrm{N},-1.40313^{\circ} \mathrm{W} ; 280 \mathrm{~m}$ a.s.l.; 14.VII.2017; same collectors as for preceding; around a irrigation well; hand capture 1 \% (SVL $106.1 \mathrm{~mm}), 1$ ơ (SVL $89.5 \mathrm{~mm})$, 1 subadult (SVL $63.8 \mathrm{~mm}$ ), 7 juveniles (SVL 29.7-35.3 mm); Koubri, on the edge of the "Ancien barrage"; $12.22883^{\circ} \mathrm{N},-1.34525^{\circ} \mathrm{W}$; $290 \mathrm{~m}$ a.s.l.; 16.VII.2017; same collectors as for preceding; hand capture 2 o $^{7}$ (SVL 85.1-95.3 mm), 1 오 (SVL 81.1-103.3 mm); Koubri, downstream of the Nabazana dam; $12.20324^{\circ} \mathrm{N},-1.35103^{\circ} \mathrm{W}$; $280 \mathrm{~m}$ a.s.l.; 17.VII.2017; same collectors as for preceding; hand capture 10 individuals; Pabré, Pabré dam; $12.51684^{\circ} \mathrm{N},-1.59690^{\circ} \mathrm{W}$; $290 \mathrm{~m}$ a.s.l.; 12.VII.2017; same collectors as for preceding; in the water of the irrigation ditch upstream of the dam; field direct observation 11 subadult (SVL $47.1 \mathrm{~mm}$ ); Deux Balés National Park, Ouahabou bouli; $11.60765^{\circ} \mathrm{N},-3.06033^{\circ} \mathrm{W} ; 260 \mathrm{~m}$ a.s.l.; 8.XI.2017; H. J. Ayoro leg.; hand capture $\bullet 1$ \% (SVL $67.1 \mathrm{~mm}$ ); Deux Balés National Park, Tiona pond; $11.63242^{\circ} \mathrm{N},-2.85433^{\circ} \mathrm{W} ; 270 \mathrm{~m}$ a.s.l.; 
9.XI.2017; same collector as for preceding; in the pond; hand capture 4 \% (SVL 66.3-80.4 mm); 3 subadults (SVL 48.0-55.1 mm); Deux Balés National Park, on the flooded zone of Mouhoun River; $11.77886^{\circ} \mathrm{N},-2.91243^{\circ} \mathrm{W} ; 240 \mathrm{~m}$ a.s.l.; $10 . \mathrm{XI} .2017$; same collector as for preceding; on the edge of a pond, hand capture 2 \% (SVL 83.6$92.1 \mathrm{~mm}$ ); W National Park, Kabougou River (500 m north-west of the Kabougou forest post office); $11.97060^{\circ} \mathrm{N}, 2.01622^{\circ} \mathrm{E}$; $280 \mathrm{~m}$ a.s.l.; 3.II.2017; same collector as for preceding; in the water of a irrigated well; hand capture 2 o (SVL 79.9-84.6 mm); same locality; 18.VI.2018; same collector as for preceding; hand capture - $1 \mathrm{O}^{\text {T }}$ (SVL $100.5 \mathrm{~mm}$ ); W National Park, a small pond (1 km southwest of the Kabougou forest post office); $11.93675^{\circ} \mathrm{N}, 1.99463^{\circ} \mathrm{E}$; $310 \mathrm{~m}$ a.s.l.; 21.VI.2018; same collector as for preceding; hand capture $\bullet 4$ individuals; W National Park, PK-27 bouli; $11.88741^{\circ} \mathrm{N}$, $2.11913^{\circ} \mathrm{E} ; 280 \mathrm{~m}$ a.s.l. 20.VI.2018; same collector as for preceding; on the edge of the bouli; field direct observation -5 individuals; W National Park, Nangouli swampy valley; $11.89804^{\circ} \mathrm{N}, 2.00101^{\circ} \mathrm{E}$; $250 \mathrm{~m}$ a.s.l.; 21.VI.2018; same collector as for preceding; on the small river bank; field direct observation 11 \% (SVL $82.2 \mathrm{~mm}$ ); Arly National Park, the Bouliabou pond; $11.57890^{\circ} \mathrm{N}, 1.46393^{\circ} \mathrm{E}$; $170 \mathrm{~m}$ a.s.l.; 11.VI.2018; same collector as for preceding; on the edge of the pond; hand capture 1 1 $($ SVL $84.2 \mathrm{~mm}), 10^{\pi}$; Arly National Park, on a floodplain $(500 \mathrm{~m}$ north of the Bouliabou pond); $11.57854^{\circ} \mathrm{N}, 1.46000^{\circ} \mathrm{E} ; 260 \mathrm{~m}$ a.s.l.; 16.VI.2018; same collector as for preceding; hand capture, field direct observation - $10^{7}$ (SVL $79.1 \mathrm{~mm}$ ), 1 \% (SVL $75.0 \mathrm{~mm}$ ); Arly National Park, on the bank of the Arly River; $11.57840^{\circ} \mathrm{N}, 1.46143^{\circ} \mathrm{E} ; 170 \mathrm{~m}$ a.s.l.; 17.VI.2018; same collector as for preceding; near a small water body; hand capture $\bullet 2$ subadults (SVL36.0-43.4 mm); ComoéLéraba Forest, a flooded zone of Comoé River $(300 \mathrm{~m}$ west of the bridge of Comoé River); $9.93242^{\circ} \mathrm{N},-4.60654^{\circ} \mathrm{W} ; 220 \mathrm{~m}$ a.s.l.; 5.VIII.2018; H. J. Ayoro \& A. Ohler leg.; near a water body; hand capture -3 individuals; Kou Forest; $11.18888^{\circ} \mathrm{N},-4.43944^{\circ} \mathrm{W}$ $260 \mathrm{~m}$ a.s.l.; 7-9.VIII.2018; same collectors as for preceding; near the water source of the Guinguette; field direct observation -4 o (SVL 67.1-104.8 mm), 1 subadult (SVL $39 \mathrm{~mm}$ ); Dori, on the edge of Dori pond near Wiindou bridge; $14.03665^{\circ} \mathrm{N},-0.04933^{\circ} \mathrm{W}$; $260 \mathrm{~m}$ a.s.l.; 22.VIII.2018; H. J. Ayoro leg.; hand capture $440^{\circ}$ (SVL 75.0-102.1 mm), 5 o (SVL 93.7-111.3 mm); the Dori pond, Toorodi; $14.00385^{\circ} \mathrm{N},-0.02411^{\circ} \mathrm{W} ; 270 \mathrm{~m}$ a.s.l.; 24 .VIII.2018; same collector as for preceding; hand capture $1 \mathrm{O}^{\top}$ (SVL $95.3 \mathrm{~mm}$ ); N'Djomga village pond; $14.07222^{\circ} \mathrm{N},-0.04865^{\circ} \mathrm{W} ; 270 \mathrm{~m}$ a.s.l.; 25.VIII.2018; same collector as for preceding, on the edge of the pond; hand capture $\bullet 1 \mathrm{O}^{\text {" }}$ (SVL $92.8 \mathrm{~mm}$ ); Yakouta, downstream from the Yakouta dam; $14.07454^{\circ} \mathrm{N},-0.14290^{\circ} \mathrm{W} ; 280 \mathrm{~m}$ a.s.l.; 26.VIII.2018; same collector as for preceding; hand capture $\bullet 2$ ? (SVL 65.1-95.2 mm); Koti; 20.X.2017; same collector as for preceding; in the stagnant water around a water fountain; hand capture $\bullet 6$ individuals; Dédougou; $12.49204^{\circ} \mathrm{N},-3.43575^{\circ} \mathrm{W}$; $300 \mathrm{~m}$ a.s.l.; 22.VIII.2017; same collector as for preceding; in a wetland of SONATUR habitations; field direct observation - Ioba province, Djikologo in Bontioli reserve; $10.93684^{\circ} \mathrm{N},-3.13804^{\circ} \mathrm{W}$ $260 \mathrm{~m}$ a.s.l.; 2011; J. Penner leg.; field direct observation $\bullet$ Dano, Batiara; $11.21322^{\circ} \mathrm{N},-3.02685^{\circ} \mathrm{W} ; 280 \mathrm{~m}$ a.s.l.; 21.X.2003; M.O. Rödel \& T. Moritz leg.; field direct observation.

Literature REPORTS. - Burkina Faso - Passoré province, Yako: $12.96740^{\circ} \mathrm{N},-2.26151^{\circ} \mathrm{W} ; 330 \mathrm{~m}$ a.s.l.; 1962 (Schiøtz 1967) - Gourma province, Fada N'gourma; $12.06051^{\circ} \mathrm{N}, 0.34913^{\circ} \mathrm{E} ; 300 \mathrm{~m}$ a.s.l. (Böhme et al. 1996; Mohneke 2011; Mohneke et al. 2011) - Ganzourgou province, Mogtedo; $12.31844^{\circ} \mathrm{N},-0.83601^{\circ} \mathrm{W} ; 280 \mathrm{~m}$ a.s.l. (Mohneke 2011) $\bullet \mathrm{Zam} ; 12.32885^{\circ} \mathrm{N},-0.82631^{\circ} \mathrm{W} ; 280 \mathrm{~m}$ a.s.l (Mohneke 2011; Mohneke et al. 2011) - Zorgho; $12.2483^{\circ} \mathrm{N}$, $-0.6278^{\circ} \mathrm{W} ; 300 \mathrm{~m}$ a.s.1.; I-III.2008 (Mohneke et al. 2010b; Mohneke 2011; Mohneke et al. 2011).

DESCRIPTION. - On 84 specimens examined, males' SVL between 66.0-105.2 mm (19 specimens) while females' sizes between 69$111.3 \mathrm{~mm}$ (38 specimens). Large and robust aquatic frogs. Eyes very prominent, in dorsal position. Head moderately broad with a rounded tympanum. Legs very strong and long, toes fully webbed. Dorsal skin with short warty and discontinuous folds, rather irregularly arranged. The dominant colouration greenish or grey olive on the back and white with some dark spots on the belly. juveniles showing a characteristic light yellow to green interorbital line.

HABITAT. - Hoplobatrachus occipitalis is usually collected near or in water (Rödel 2000). In the dry season it lives in rivers, pond banks and in irrigated wells. It is found in practically all freshwater habitats in wet season. Migrations were related in the dry season to the edge of rivers and the in wet season to surroundings of ponds (Spieler 1997). The species was observed on clayey and sandy soils. This frog is an important source of animal protein in the nutrition of local population from the south-eastern part of Burkina Faso (Mohneke et al. 2010b, 2011).

\section{Family Hemisotidae Cope, 1867}

Hemisus marmoratus (Peters, 1854) (Fig. 4A)

COLleCtion MATERIAL. — Burkina Faso • 3 ơ (SVL 26.8-31.8 mm), 4 우 (SVL 33.3-36.4 mm); Passoré province, Samba; $12.70144^{\circ} \mathrm{N}$, $-2.40390^{\circ} \mathrm{W} ; 290 \mathrm{~m}$ a.s.l.; 14.VII.1962; M. Lamotte leg.; MNHNRA-1979.156, 1979.159, 1979.160, 1979.162, 1979.152, 1979.154, $1979.155 \cdot 29$ tadpoles; Samba; I.1963; $\left(12.701480^{\circ} \mathrm{N},-2.40537^{\circ} \mathrm{W}\right.$; 290 m a.s.l.; M. Lamotte leg.; MNHN-RA-2006.4833, 2006.4834, 2006.4835, 2006.4836, 2006.4837, 2006.4838, 2006.4839, 2006.4840, 2006.4841, 2006.4842, 2006.4843, 2006.4844, $2006.4845,2006.4846,2006.4847,2006.4848,2006.4849$, 2006.4850, 2006.4851, 2006.4852, 2006.4853, 2006.4854, 2006.4855, 2006.4856, 2006.4857, 2006.4858, 2006.4859, 2006.4860, 2006.4861.

Field MATERIAL. - Burkina Faso • $30^{7}$ (SVL 29.2-30.6 mm); Comoé-Léraba Forest, Baboro swampy valley; $9.92521^{\circ} \mathrm{N},-4.57574^{\circ} \mathrm{W}$; 240 m a.s.l.; 4.VIII.2018; H. J. Ayoro \& A. Ohler leg.; under grasses close to a small water body; hand capture 1 P(SVL $41.7 \mathrm{~mm})$; Koubri, "Ancien barrage"; $12.22882^{\circ} \mathrm{N},-1.34527^{\circ} \mathrm{W} ; 285$ m a.s.l.; 16.VII.2017; same collectors as for preceding; at edge of a paddy field; hand capture 1 \% (SVL $41.3 \mathrm{~mm})$; W National Park; $11.95738^{\circ} \mathrm{N}$, $2.01381^{\circ} \mathrm{E} ; 290 \mathrm{~m}$ a.s.1.; 20.VI.2018; H. J. Ayoro leg.; near a trail; hand capture 1 \% (SVL $30.3 \mathrm{~mm})$; Dori, $300 \mathrm{~m}$ from the N'Djomga village pond; $14.07222^{\circ} \mathrm{N},-0.04860^{\circ} \mathrm{W} ; 270 \mathrm{~m}$ a.s.l. 25.VIII.2018; same collector as for preceding; at the border of a millet field; hand capture 1 subadult (SVL $26.7 \mathrm{~mm}$ ); Yakouta, downstream from the Yakouta dam; $14.07452^{\circ} \mathrm{N},-0.14290^{\circ} \mathrm{W}$; $280 \mathrm{~m}$ a.s.l.; 26.VIII.2018; same collector as for preceding; near the asphalted road; hand capture 11 subadult (SVL $26.2 \mathrm{~mm}$ ); Koti; $11.38778^{\circ} \mathrm{N},-3.06400^{\circ} \mathrm{W} ; 310 \mathrm{~m}$ a.s.l.; $15 . I X .2018$; same collector as for preceding; in a bean field; hand capture $\bullet 10^{7}$; Arly National Park, floodplain; $11.57851^{\circ} \mathrm{N}, 1.46000^{\circ} \mathrm{E} ; 260 \mathrm{~m}$ a.s.l.; 16 .VI.2018; same collector as for preceding; near a small water body surrounded by grasses; acoustic report $-20^{7}$; W National Park; the edge of a small pond (1 km south-west of the Kabougou forest post office); $11.93671^{\circ} \mathrm{N}, 1.99463^{\circ} \mathrm{E} ; 310 \mathrm{~m}$ a.s.l.; 21.VI.2018; same collector as for preceding; acoustic report.

Literature REPORTS. - Burkina Faso - Passoré province, Yako: $12.96740^{\circ} \mathrm{N},-2.26151^{\circ} \mathrm{W} ; 330 \mathrm{~m}$ a.s.l.; 1962 (Schiøtz 1967) • BoboDioulasso, halfway between Bobo-Dioulasso and Ouagadougou; coordinates not available; 31.VII.1992 (Böhme et al. 1996) • Gourma province, Fada N'gourma; $12.06051^{\circ} \mathrm{N}, 0.34913^{\circ} \mathrm{E} ; 300 \mathrm{~m}$ a.s.l. (Mohneke 2011; Mohneke et al. 2011) • Ganzourgou province, Mogtedo; $12.31844^{\circ} \mathrm{N},-0.83601^{\circ} \mathrm{W} ; 280 \mathrm{~m}$ a.s.l. (Mohneke 2011; Mohneke et al. 2011) $\bullet \mathrm{Zam} ; 12.32885^{\circ} \mathrm{N},-0.82631^{\circ} \mathrm{W} ; 280 \mathrm{~m}$ 
a.s.l; (Mohneke 2011; Mohneke et al. 2011); • Zorgho; $12.2483^{\circ} \mathrm{N}$ $-0.6278^{\circ} \mathrm{W} ; 300 \mathrm{~m}$ a.s.l.; I-III.2008 (Mohneke et al. 2010b; Mohneke 2011; Mohneke et al. 2011) - Houet province, Karankasso vigué; $11.00978^{\circ} \mathrm{N},-3.90001^{\circ} \mathrm{W} ; 300 \mathrm{~m}$ a.s.l.; 2015 (Böhme \& Heath 2018).

DESCRIPTION. - 15 specimens examined. Small frogs with a triangular head and a very pointed and short snout. Morphologically sturdy with strong limbs, adapted for burrowing (Fig. 4A). Skin soft and smooth (Laurent 1972; Rödel 2000). Dorsal colouration of living frogs yellowish with some dark brown spots on the back. In alcohol, yellow colour whitish dorsally and ventrally.

HaвITAT. - Hemisus marmoratus was difficult to see during our survey periods and is probably much more abundant in convenient habitat and at the right saison. We found this fossorial species in the vicinity of a paddy field on the "Ancien barrage" edge in Koubri, on a trail leading to a small water body in W National Park. We heard the male calling under flooded grasses around a pond ( $1 \mathrm{~km}$ southwest of the Kabougou forest post office) in W National Park. The species was also found in Baboro swampy valley in Comoé-Léraba where males could be heard calling among grasses nearby a small water body in Folonzo village swampy valley on 6 August 2018 . This was unusual as Hemisus usually breeds in the early rainy season or even before the rains set in (see e.g. Rödel et al. 1995; Kaminsky et al. 1999). In a floodplain near Bouliabou pond, we heard males calling and recorded three males in Arly National Park. In the Sahelian part, we captured this species during rainy weather on sandy soils close to a millet field in N'Djomga and on the roadside in Yakouta. Hemisus marmoratus is mostly fossorial, in relatively moist, loose soils and is often captured during earthworks such as plowing fields (Lamotte \& Xavier 1981; Rödel 2000).

The species is common and reported having a wide distribution range from West Africa south to Angola and South Africa (Laurent 1972; Rödel 2000). However, several cryptic taxa are probably mixed under this name (M.-O. Rödel, unpublished data).

\section{Family HYPEROLIIDAE Laurent, 1943}

\section{Afrixalus vittiger (Peters, 1876)} (Fig. 4B)

COLLECTION MATERIAL. - Burkina Faso • 2 9 (SVL 21.6-27.4 mm), 1 subadult (SVL $18 \mathrm{~mm}$ ); Passoré province, Samba; $12.70144^{\circ} \mathrm{N}$, $-2.40390^{\circ} \mathrm{W} ; 290$ m a.s.l.; VII.1962; M. Lamotte leg.; MNHNRA-1979.4741, 1979.4742, 1979.4743.

Field MATERIAL. - Burkina Faso • $800^{7}$ (SVL 24.5-27.0 mm); Pabré dam, downstream of the dam; $12.51679^{\circ} \mathrm{N},-1.59693^{\circ} \mathrm{W} ; 290 \mathrm{~m}$ a.s.l.; 11.VII.2017; H. J. Ayoro \& A. Ohler leg.; on flooded grasses; hand capture • $2 \mathrm{O}^{7}$ (SVL 23.7-24.5 mm); same locality; 12.VII.2017; same collectors as for preceding; on grasses in irrigation ditch; hand capture • $3 \mathrm{o}^{7}$ (SVL 24.3-25.2 mm), 1 \% (SVL $26.7 \mathrm{~mm}$ ); Loumbila dam; $12.49844^{\circ} \mathrm{N},-1.40311^{\circ} \mathrm{W} ; 280 \mathrm{~m}$ a.s.l.; 14 .VII.2017; same collectors as for preceding; in a plantain plantation downstream from the dam; hand capture $\bullet 80^{\prime \prime}$ (SVL 24.3-26.7 mm); same locality; 15.VII.2017; same collectors as for preceding; on small plants around vegetable gardens; hand capture $\bullet 4$ O" (SVL 23.4$25.2 \mathrm{~mm}$ ); Koubri, "Ancien barrage"; $12.20322^{\circ} \mathrm{N},-1.35100^{\circ} \mathrm{W}$ $280 \mathrm{~m}$ a.s.l.; 16.VII.2017; same collectors as for preceding; in a maize field; hand capture $\bullet 20^{7}$ (SVL 22.8-24.3 mm); Koubri, downstream from the Nabazana dam; $12.20322^{\circ} \mathrm{N},-1.35101^{\circ} \mathrm{W}$; $280 \mathrm{~m}$ a.s.l.; 17.VII.2017; same collectors as for preceding; on the edge of a paddy field; hand capture $\bullet 2$ (SVL 23.4-27.3 mm); Koubri, downstream from Arzoumbaongo dam; $12.22064^{\circ} \mathrm{N}$, $-1.29590^{\circ} \mathrm{W} ; 270 \mathrm{~m}$ a.s.l.; 18.VII.2017; same collectors as for preceding; on shrubs near water body; hand capture $\bullet 1$ subadult (SVL $17.1 \mathrm{~mm}$ ); Deux Balés National Park, downstream from the Soumbou dam; $11.69830^{\circ} \mathrm{N},-2.79711^{\circ} \mathrm{W} ; 260 \mathrm{~m}$ a.s.l.; 8.XI.2017; H. J. Ayoro leg.; on dry grasses near the water body; hand capture - 3 subadults; Deux Balés National Park, edge of Kohéna pond; $11.67661^{\circ} \mathrm{N},-2.83614^{\circ} \mathrm{W} ; 270 \mathrm{~m}$ a.s.l.; 9.XI.2017; same collector as for preceding; on the mud near water body; direct observation in field $\bullet 2$ (SVL 21.0-21.7 mm); Arly National Park, a floodplain; $11.57855^{\circ} \mathrm{N}, 1.46001^{\circ} \mathrm{E} ; 260 \mathrm{~m}$ a.s.l.; 16-17.VI.2018; same collector as for preceding; on stones near the water body; hand capture - $40^{7}$ (SVL 21.9-24.8 mm), 2 9 (SVL 21.3-23.1 mm); W National Park, Kabougou River $(500$ m north-west of the Kabougou forest post office); $11.97060^{\circ} \mathrm{N}, 2.01622^{\circ} \mathrm{E} ; 280 \mathrm{~m}$ a.s.l.; 18 .VI.2018; same collector as for preceding; on grasses; hand capture $110^{\prime \prime}$ (SVL 20.9-23.6 mm), 4 9 (SVL 23.8-24.8 mm); the protected part of Kabougou River (500 m north-east of the Kabougou forest post office); $11.96865^{\circ} \mathrm{N}, 2.0125^{\circ} \mathrm{E} ; 280 \mathrm{~m}$ a.s.l.; 19. VI.2018; same collector as for preceding; on grasses $\bullet 20^{\prime \prime}($ SVL 21.3-22.0 mm); the edge of PK-27 bouli; $11.88744^{\circ} \mathrm{N}, 2.11913^{\circ} \mathrm{E} ; 265 \mathrm{~m}$ a.s.l.; 20.VI.2018; same collector as for preceding; on grasses; hand capture - 4 ơ (SVL 22.7-24.1 mm), 1 9 (SVL 25.2 mm); Comoé-Léraba Forest, Sirigoué swampy valley; $9.88811^{\circ} \mathrm{N},-4.61950^{\circ} \mathrm{W} ; 230 \mathrm{~m}$ a.s.l.; 2.VIII.2018; H. J. Ayoro \& A. Ohler leg.; on shrubs and grasses; hand capture • $20^{7}$ (SVL 22.7-23.5 mm), 1 ㅇ (SVL $\left.25.9 \mathrm{~mm}\right)$; Kotokoi swampy valley; $9.82802^{\circ} \mathrm{N},-4.62727^{\circ} \mathrm{W} ; 230 \mathrm{~m}$ a.s.l.; 3.VIII.2018; same collectors as for preceding; on grasses; hand capture $\bullet$ Kou Forest, bank of Kou River; $11.18720^{\circ} \mathrm{N},-4.44185^{\circ} \mathrm{W}$; $340 \mathrm{~m}$ a.s.l.; 8.VIII.2018; same collectors as for preceding; on shrubs around the river bank; acoustic report $\bullet$ Ioba province, Gbagba (near Dano); $11.18133^{\circ} \mathrm{N},-3.05165^{\circ} \mathrm{W} ; 300 \mathrm{~m}$ a.s.l.; 2011 ; J. Penner leg.; direct observation in field.

LITERATURE REPORTS. — Burkina Faso • Ouagadougou; $12.38009^{\circ} \mathrm{N}$, $-1.51100^{\circ} \mathrm{W} ; 300 \mathrm{~m}$ a.s.l.; 30.VII.1992 (Böhme et al. 1996) • Yako; $12.96740^{\circ} \mathrm{N},-2.26151^{\circ} \mathrm{W} ; 330 \mathrm{~m}$ a.s.l.; 18.VIII.1961 (Schiøtz 1967).

DESCRIPTION. - 71 specimens examined. Some of these specimens slightly larger than others. Male's body size between 20.9-27.3 mm while female's size 21.3-26.7 mm. Agreeing with Pickersgill (2007), indicating males body size from 21-26 mm and 22-28 $\mathrm{mm}$ for females. Skin asperities, typical for the genus, present on dorsum but also on belly, prominent on tarsus and feet in males. On back of all specimens, seven vertical distinct bands, four brown separated by three whitish (Fig. 4B). Ventral skin colour whitish.

НАвІтAт. - We observed A. vittiger in floodplains and swampy valleys. The species is present in protected areas such as Arly National Park, W National Park, Comoé-Léraba Forest and Deux Balés National Park. In Koubri, Pabré and Loumbila, the species was found in paddy fields, around ponds on grasses and plants surfacing water (Fig. 2C, D, F). It is a common savannah species which has a large distribution range in West Africa (Rödel 2000; Leaché et al. 2006; Nago et al. 2006; Segniagbeto et al. 2007). This species has often been confused with its congener $A$. fulvovittatus. The two species partly overlap in the forest-savannah ecotone of West Africa. However, Afrixalus fulvovittatus occurs in heavily degraded forest areas whereas A. vittiger mostly lives in savannah areas (Pickersgill 2007; Rödel \& Glos 2019).

\section{Afrixalus weidholzi (Mertens, 1938)} (Fig. 4C)

Field MATERIAL. - Burkina Faso • $23 \mathrm{o}^{\prime \prime}$ (SVL 17.4-21.2 mm); Comoé-Léraba Forest; $9.82802^{\circ} \mathrm{N},-4.62727^{\circ} \mathrm{W} ; 230 \mathrm{~m}$ a.s.l; 1-7.VIII.2018; H. J. Ayoro \& A. Ohler leg.; on grasses in a swampy valley; hand capture $10^{\text {*; }}$; W National Park, Kabougou River (in its protected part); $11.96865^{\circ} \mathrm{N}, 2.0125^{\circ} \mathrm{E} ; 280 \mathrm{~m}$ a.s.l.; 19. VI.2018; 

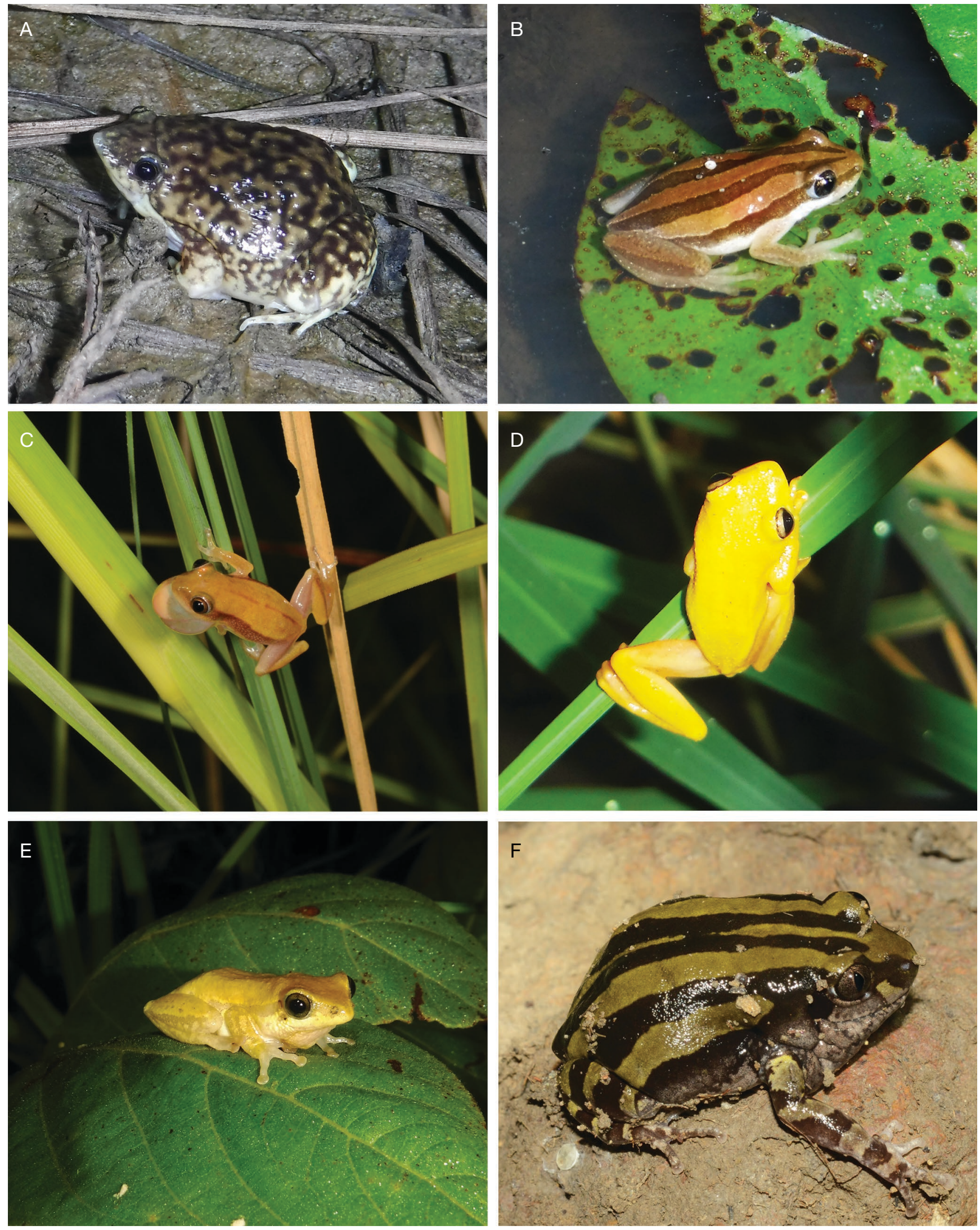

FIG. 4. - Representatives of anuran species from Burkina Faso in life. A, Hemisus marmoratus (Peters, 1854); B, Afrixalus vittiger (Peters, 1876) C, Afrixalus weidholzi (Mertens, 1938); D, Hyperolius concolor concolor (Hallowell, 1844); E, Hyperolius nitidulus Peters, 1875; F, Kassina cassinoides (Boulenger, 1903). Photos: Halamoussa Joëlle Ayoro. 
H. J. Ayoro leg.; in a bush near water body; acoustic report $\bullet 10^{\text {'; }}$ Koubri, downstream from the Nabazana dam; $12.20322^{\circ} \mathrm{N},-1.35101^{\circ} \mathrm{W}$; 280 m a.s.l.; 17.VII.2017; H. J. Ayoro \& A. Ohler leg.; close to a paddy field; acoustic report.

DESCRIPTION. - 23 specimens examined. Frogs with SVL from $17.4-21.2 \mathrm{~mm}$ in 23 males, smaller than $A$. vittiger. Specimens with a yellow or a very intense silvery white back (Fig. 4C), often with a fine brown vertebral line, at least in the posterior part of the back. Laterally, a less distinct dark band from the snout to the groin. On the shank, presence of dark brown longitudinal bands.

HABITAT. - This species was usually collected on grass at a height not exceeding $0.5-1.5 \mathrm{~m}$ (Fig. 2D). During the day, resting animals can be found above water on plants (Lamotte \& Xavier 1981; Schiøtz 1967, 1999). Males call at night, usually on high grasses, a few meters from the pond edges (Rödel et al. 2006). Afrixalus weidholzi is a common species which has a wide range in West African drier savannah zones (Rödel 2000; Padial et al. 2013) and occurs occasionally in the same habitats as $A$. vittiger.

\section{Hyperolius concolor concolor (Hallowell, 1844)} (Fig. 4D)

COLleCtiOn MATERIAL. - Burkina Faso • $20^{\text {o }}$; (SVL 27.2-28.4 mm); Houet province, Sokourani (near Hippopotamus pond); $11.51183^{\circ} \mathrm{N}$, $-4.11611^{\circ} \mathrm{W} ; 320 \mathrm{~m}$ a.s.l.; 8.XI.1970; M. Lamotte leg.; MNHNRA-1999.7211, 1999.7212.

FIELD MATERIAL. — Burkina Faso • $2 \mathrm{O}^{7}$ (SVL 27.8-29.5 mm); ComoéLéraba Forest, Sirigoué swampy valley; $9.88809^{\circ} \mathrm{N},-4.61954^{\circ} \mathrm{W}$ $230 \mathrm{~m}$ a.s.l.; 2.VIII.2018; H. J. Ayoro \& A. Ohler leg.; on flooded grasses; hand capture • $50^{7}$ (SVL 30.3-31.7 mm); Comoé-Léraba Forest, Baboro swampy valley; $9.92522^{\circ} \mathrm{N},-4.57575^{\circ} \mathrm{W} ; 240 \mathrm{~m}$ a.s.l.; 4.VIII.2018; same collectors as for preceding; on high, flooded grasses; hand capture $11 \mathrm{O}^{\text {' }}$ (SVL $\left.29.7 \mathrm{~mm}\right)$; Kou Forest, near the Guinguette water source; $11.18720^{\circ} \mathrm{N},-4.44185^{\circ} \mathrm{W} ; 340 \mathrm{~m}$ a.s.l.; 7.VIII.2018; same collectors as for preceding; on leaves of palm trees; hand capture.

DESCRIPTION. - 10 specimens examined. Only males collected, with SVL 27.8-31.5 mm. Life colouration yellowish to greenish (Fig. 4D). Usually during the day, males more brownish to yellow, often with some dark dorsal pattern, whereas females showing a green colouration. At night individuals of both sexes with a yellow colour (Rödel 2000). In alcohol, specimens whitish with small black spots, visible only with a dissecting microscope.

HABITAT. - Hyperolius concolor concolor was found on flooded grasses in Comoé-Léraba Forest and on palm leaves at the source of the Guinguette River in Kou Forest. Specimens were usually sitting comparatively higher than $H$. nitidulus, but see Rödel et al. (2006) for calling site position in various West African hyperoliids. The species is known to occur in areas of degraded forests and humid savannah; it extends into drier savannah zones along gallery forests (Schiøtz 1999; Rödel 2000). It is distributed in West Africa from Sierra Leone to northern Benin (Schiøtz 1999; Rödel 2000; Nago et al. 2006).

\section{Hyperolius lamottei Laurent, 1958} (Fig. 7B)

COLLECTION MATERIAL. - Burkina Faso • 1 9 (SVL 21.6 mm); Léraba province, Katiaré (north-east of Ferké) close to Ivorian border; 9.91200 ${ }^{\circ} \mathrm{N},-4.94776^{\circ} \mathrm{W} ; 250 \mathrm{~m}$ a.s.l.; $10 . X I .1970 ;$ M. Lamotte leg.; MNHN-RA-1997.9889.

DESCRIPTION. - Female with a SVL of $21.6 \mathrm{~mm}$. A small savannah frog with a SVL of 20-27 mm of both sexes (Lamotte \& Xavier 1981;
Schiotz 1999). Data based on additional specimens from various West African localities: males smaller than females; Ivory Coast 38 ơ (19.5-23.1 mm), 32 \% (20.3-26.1 mm); Guinea $32 \mathrm{o}^{\circ}$ (18.0$23.4 \mathrm{~mm}), 27$ क (20.0-24.4 mm); Liberia 27 ơ (19.5-23.8 mm), 37 ㅇ (20.3-28.1 mm); Sierra Leone 54 o (19.3-23.7 mm), 28 ㅇ (21.8-27.3 mm). Slender frog, as Afrixalus vittiger. Back with 9 longitudinal bands: four white and five brown (Fig. 7B); see also figures in Schiøtz (1999), Rödel \& Ernst (2003), Adeba et al. (2010) and Channing et al. (2013).

HABITAT. - Hyperolius lamottei was collected in Katiaré, north-east of Ferké region. This locality is situated in Cascades region in Burkina Faso, characterized by savannah and gallery forest areas with waterfalls, hills and cliffs. Based on the collection data of MNHN specimens from others localities of West Africa, H. lamottei inhabits wet savannah zones and seems to have a preference for montane regions such as the Nimba, Loma and Péko mountains (Lamotte 1971; Rödel \& Ernst 2003; Rödel et al. 2004), where it inhabits short grassland savannahs, often on granite ground (Schiøtz 1967; Rödel \& Ernst 2003). The Burkina Faso record is thus very unexpected and future field work should try to confirm its presence at the locality mentioned above and other similar sites.

\section{Hyperolius nitidulus Peters, 1875}

(Fig. 4E)

Collection material. - Burkina Faso • 1 ㅇ (SVL $24.1 \mathrm{~mm}$ ), $2 \mathrm{O}^{7}$ (SVL 19-27.5 mm); Passoré province, Samba; $12.70144^{\circ} \mathrm{N}$, $-2.40390^{\circ} \mathrm{W} ; 290 \mathrm{~m}$ a.s.l.; 18.VII.1961; NA leg.; MNHNRA-2000.3113, 2000.3114, 1979.3724 • 4 o $^{\circ}($ SVL 18.9-24 mm); Pabré; $12.51000^{\circ} \mathrm{N},-1.57953^{\circ} \mathrm{W} ; 290 \mathrm{~m}$ a.s.l.; 1963 ; M. Lamotte leg.; MNHN-RA-2000.3115, 2000.3116, 2000.5609, 2000.5606.

Field MATERIAL. - Burkina Faso - $40^{7}$ (SVL 27.3-29.0 mm); Pabré dam, downstream of the dam; $12.51685^{\circ} \mathrm{N},-1.59687^{\circ} \mathrm{W}$; 290 m a.s.l.; 11.VII.2017; H. J. Ayoro \& A. Ohler leg.; on grasses; hand capture $110^{\circ}$ (SVL $29.4 \mathrm{~mm}$ ); Loumbila dam; $12.49844^{\circ} \mathrm{N},-1.40311^{\circ} \mathrm{W} ; 280 \mathrm{~m}$ a.s.l.; 14 .VII.2017; same collectors as for preceding; on aquatic plants near a plantain field; hand capture $880^{\text {" }}$ (SVL 29.3-32.0 mm); Koubri, "Ancien barrage"; $12.22878^{\circ} \mathrm{N},-1.34522^{\circ} \mathrm{W} ; 290 \mathrm{~m}$ a.s.l.; $16 . V I I .2017$; same collectors as for preceding; in a maize field near water body; hand capture - $10^{\text {; }}$; Deux Balés National Park, downstream from Soumbou dam; $11.69833^{\circ} \mathrm{N},-2.79713^{\circ} \mathrm{W} ; 260 \mathrm{~m}$ a.s.l.; 8.XI.2017; H. J. Ayoro leg.; on aquatic plants; acoustic report $\bullet 20^{7}$ (SVL 23.2-24.9 mm); W National Park, near the Kabougou forest post office; $11.95738^{\circ} \mathrm{N}, 2.01381^{\circ} \mathrm{E} ; 290 \mathrm{~m}$ a.s.l.; 20.VI.2018; same collector as for preceding; on shrubs; hand capture $14 \mathrm{O}^{\text {"7 }}$ (SVL 25.7-28.4 mm), 1 † (SVL 30.6 mm); Comoé-Léraba Forest, Sirigoué swampy valley; $9.88809^{\circ} \mathrm{N},-4.61954^{\circ} \mathrm{W} ; 230 \mathrm{~m}$ a.s.l.; 2.VIII.2018; H. J. Ayoro \& A. Ohler leg.; around a small pond; hand capture • 5 ơ (SVL 26.8-28.4 mm); Comoé-Léraba Forest, Baboro swampy valley; $9.92522^{\circ} \mathrm{N},-4.57575^{\circ} \mathrm{W} ; 240 \mathrm{~m}$ a.s.l.; 5.VIII.2018; same collectors as for preceding; in an untilled field; hand capture $44 \mathrm{O}^{\text {" }}$ (SVL 25.5-28.0 mm); near the Comoé River bridge; $9.93239^{\circ} \mathrm{N},-4.60655^{\circ} \mathrm{W} ; 220$ m.a.s.l; 5.VIII.2018; same collectors as for preceding; on aquatic plants in small stagnant waters on the trail; hand capture $10^{7}$ (SVL $26.2 \mathrm{~mm}$ ); Folonzo village swampy valley; $9.88803^{\circ} \mathrm{N},-4.61969^{\circ} \mathrm{W} ; 230 \mathrm{~m}$ a.s.l.; 6.VIII.2018; same collectors as for preceding; near a vegetable garden; hand capture $\bullet 5 \mathrm{o}^{7}$; Kou Forest; $11.18888^{\circ} \mathrm{N},-4.43944^{\circ} \mathrm{W}$; $260 \mathrm{~m}$ a.s.1.; 7-9.VIII.2018; same collectors as for preceding; on shrubs and grasses around a water body; acoustic report $\bullet$ Ioba province, Bontioli reserve; $10.93682^{\circ} \mathrm{N},-3.13804^{\circ} \mathrm{W} ; 260 \mathrm{~m}$ a.s.l.; J. Penner leg. - Dano; $11.16681^{\circ} \mathrm{N},-3.08870^{\circ} \mathrm{W} ; 330 \mathrm{~m}$ a.s.l. and $11.16464^{\circ} \mathrm{N},-3.08633^{\circ} \mathrm{W} ; 340 \mathrm{~m}$ a.s.l.; 2011 ; J. Penner leg.; field direct observation. 
Literature REPORTS. - Burkina Faso • Gourma province, Fada $\mathrm{N}^{\prime}$ gourma; $12.06051^{\circ} \mathrm{N}, 0.34913^{\circ} \mathrm{E} ; 300 \mathrm{~m}$ a.s.l. (Mohneke 2011) - Ganzourgou province, Mogtedo; $12.31844^{\circ} \mathrm{N},-0.83601^{\circ} \mathrm{W} ; 280 \mathrm{~m}$ a.s.l. (Mohneke 2011) • Zorgho; $12.2483^{\circ} \mathrm{N},-0.6278^{\circ} \mathrm{W} ; 300 \mathrm{~m}$ a.s.l.; I-III.2008 (Mohneke 2011).

DESCRIPTION. - 49 specimens examined. Size of vouchers (SVL 23.231.3 for males and 28.8-30.9 mm for females) corresponding the values of Lampert (2001). In life, specimens with a yellowish back framed by dark lateral bands with narrow yellow edges, extending from the eyes back to above the legs (Fig. 4E). Sometimes, back showing a brown and greyish pattern with very small dark spots. Dorsal coloration lighter and with less contrasting pattern at night.

HABITAT. - Hyperolius nitidulus was found on grasses and bushes in floodplains, in swampy valleys and farmland such as maize and paddy fields, plantain plantations and vegetable gardens. It was also found on plants above water at nearby ponds and rivers. This species inhabits shrublands, grasslands and wetlands in the Guinean and Sudanian savannahs, from central Guinea to Cameroon (Lamotte 1967b; Rödel 2000; Rödel et al. 2010a).

\section{Kassina cassinoides (Boulenger, 1903)}

(Fig. 4F)

Collection MATERIAL. - Burkina Faso • 1 9 (SVL 53.4 mm), $10^{7}$ (SVL $44.3 \mathrm{~mm}$ ); Samba; $12.70145^{\circ} \mathrm{N},-2.40387^{\circ} \mathrm{W} ; 290 \mathrm{~m}$ a.s.l.; 13.VII.1962; M. Lamotte leg.; MNHN-RA-1998.2307, 1998.2308 - 1 juvenile (SVL $15.6 \mathrm{~mm}$ ); Kourweogo province, Laye; $12.53084^{\circ} \mathrm{N}$, $-1.77155^{\circ} \mathrm{W} ; 290 \mathrm{~m}$ a.s.l.; VIII.1966; M. Lamotte leg.; MNHNRA-1998.2309.

FIELD MATERIAL. - Burkina Faso • $10^{7}$ (SVL 44.9 mm); Pabré dam, south-west of this dam; $12.51159^{\circ} \mathrm{N},-1.58833^{\circ} \mathrm{W} ; 290 \mathrm{~m}$ a.s.l.; 10.VII.2017; H. J. Ayoro \& A. Ohler leg.; under a stone on the edge of the dam; hand capture $10^{7}$ (SVL $\left.42.4 \mathrm{~mm}\right)$; Arly National Park, close to the Bouliabou pond; $11.57892^{\circ} \mathrm{N}, 1.4638^{\circ} \mathrm{E} ; 170 \mathrm{~m}$ a.s.l.; 16.VI.2018; H. J. Ayoro leg.; near a small water body; hand capture - $10^{\pi}$ (SVL 40.1 mm); W National Park, Koubougou River (500 m north-west of the Koubougou forest post office); $11.96860^{\circ} \mathrm{N}$, $2.01259^{\circ} \mathrm{E} ; 280 \mathrm{~m}$ a.s.l.; 18.VI.2018; same collector as for preceding; in a paddy field; hand capture $11 \mathrm{O}^{\text {" }}$ (SVL $44.5 \mathrm{~mm}$ ); Folonzo village swampy valley; $9.88803^{\circ} \mathrm{N},-4.61969^{\circ} \mathrm{W} ; 230 \mathrm{~m}$ a.s.l.; 6.VIII.2018; H. J. Ayoro \& A. Ohler leg.; on a shrub, hand capture 2 o'; Loumbila dam; $12.49837^{\circ} \mathrm{N},-1.40313^{\circ} \mathrm{W} ; 285 \mathrm{~m}$ a.s.l.; 15.VII.2017; same collectors as for preceding; in a bush near the dam; acoustic report $110^{\prime \prime}$; Koubri, "Ancien barrage"; $12.22843^{\circ} \mathrm{N},-1.34766^{\circ} \mathrm{W}$ $280 \mathrm{~m}$ a.s.l.; 16.VII.2017; same collectors as for preceding; on a tree near the dam; acoustic report $\bullet 10^{\prime}$; Koubri, downstream of Nabazana dam; $12.20319^{\circ} \mathrm{N},-1.35105^{\circ} \mathrm{W} ; 280 \mathrm{~m}$ a.s.l.; 17.VII.2017; same collectors as for preceding; in vegetable garden near the dam; acoustic report $-20^{\top}$; Dédougou; $12.48972^{\circ} \mathrm{N},-3.43611^{\circ} \mathrm{W} ; 300 \mathrm{~m}$ a.s.l.; 22.VIII.2017; H. J. Ayoro leg.; under shrubs near the SONATUR city; acoustic report $\bullet 10^{7}$; W National Park, around PK-27 bouli; $11.88744^{\circ} \mathrm{N}, 2.11913^{\circ} \mathrm{W} ; 265 \mathrm{~m}$ a.s.l.; 20.VI.2018; same collector as for preceding; acoustic report $11 \mathrm{O}^{\text {\# }}$; Comoé-Léraba Forest, Sirigoué swampy valley; $9.91358^{\circ} \mathrm{N},-4.62686^{\circ} \mathrm{W} ; 240 \mathrm{~m}$ a.s.l.; 2.VIII.2018; H. J. Ayoro \& A. Ohler leg.; on a tree; acoustic report - $3 \mathrm{O}^{7}$; Kou Forest, on the bank of Kou River in the savannah part of this Forest; $11.18815^{\circ} \mathrm{N},-4.44397^{\circ} \mathrm{W} ; 375 \mathrm{~m}$ a.s.l.; 9.VIII.2018; same collectors as for preceding; on the trees; acoustic report $\bullet$ Dano dam; $11.16464^{\circ} \mathrm{N},-3.08633^{\circ} \mathrm{W} ; 340 \mathrm{~m}$ a.s.l.; 2011 ; J. Penner leg.; field direct observation.

DESCRIPTION. - 7 specimens examined. Larger than the two other Kassina species from Burkina Faso. SVL of the five observed males 40.1-44.9 mm. The female MNHN-RA-1998.2307 with $53.4 \mathrm{~mm}$
SVL exceeding the known body size (Schiøtz 1999; Rödel 2000; Amiet 2012). This species distinguished known from all other savannah frogs by a double, black vertebral line (Fig. 4F).

Habitat. - Kassina cassinoides and K. fusca Schiøtz, 1967 were calling at night from holes at the base of shrubs, at the beginning of rainy season. Three of our vouchers were collected on the ground near water (in about 10-50 m distance) in June and July. One was found on a tree where it was calling (in about $100 \mathrm{~m}$ from the water) in August. Rödel (2000) also reported that single individuals may call from trees. It is most abundant in denser vegetated parts of dry savannah (Rödel 2000; Nago et al. 2006). This species was not found in the Sahelian zone (Dori and Yakouta). Its distribution range covers a large part of the Sudano-Sahelian region in West Africa from Senegal to northeast Cameroon (Schiøtz 1999; Böhme 2005; Amiet 2012).

\section{Kassina fusca Schiøtz, 1967}

(Fig. 5A)

Collection material. - Burkina Faso • $10^{7}$ (SVL 29.5 mm), 1 ㅇ (SVL $37.3 \mathrm{~mm}$ ); Kourweogo province, Laye; $12.53083^{\circ} \mathrm{N}$, $-1.77150^{\circ} \mathrm{W} ; 290 \mathrm{~m}$ a.s.l.; 6.VIII.1966; M. Lamotte leg.; MNHNRA-1998.2011, 1998.2302.

Field MATERIAL. - Burkina Faso - $30^{7}$ (SVL 32.2-32.4 mm), 1 (SVL $35.8 \mathrm{~mm}$ ); Arly National Park, Bongola swampy valley; $11.53252^{\circ} \mathrm{N}, 1.48241^{\circ} \mathrm{E} ; 170 \mathrm{~m}$ a.s.l.; 13.VI.2018; H. J. Ayoro leg.; at the base of shrubs; hand capture $1 \mathrm{O}^{7}$ (SVL $\left.32.0 \mathrm{~mm}\right), 1$ 우 (SVL $31.4 \mathrm{~mm}$ ); Arly National Park, in the floodplain; $11.57852^{\circ} \mathrm{N}$, $1.46004^{\circ} \mathrm{E} ; 255 \mathrm{~m}$ a.s.l.; $16 . V I .2018$; same collector as for preceding; in a bare space; hand capture $110^{7}$; W National Park, around the PK-27 bouli; $11.88744^{\circ} \mathrm{N}, 2.11913^{\circ} \mathrm{W} ; 265 \mathrm{~m}$ a.s.l.; 20.VI.2018; same collector as for preceding; in a bush near the water body; acoustic report • $60^{7}$ (SVL 32.2-35.5 mm), 4 \% (SVL 32.8-36.5 mm); W National Park, the edge of a temporary pond $(1 \mathrm{~km}$ south-west of the Kabougou forest post office); $11.93669^{\circ} \mathrm{N}, 1.99464^{\circ} \mathrm{E}$; $310 \mathrm{~m}$ a.s.l.; 21.VI.2018; same collector as for preceding; near water body; hand capture $110^{\text {` }}$ (SVL $29.8 \mathrm{~mm}$ ); Comoé-Léraba Forest; $9.88803^{\circ} \mathrm{N}$, $4.61969^{\circ} \mathrm{W} ; 230 \mathrm{~m}$ a.s.l.; 5.VIII.2018; H. J. Ayoro \& A. Ohler leg.; near a maize field (50 $\mathrm{m}$ of the forest); hand capture - $1 \mathrm{O}^{7}$ (SVL $32.4 \mathrm{~mm}$ ); Folonzo village swampy valley; $9.95777^{\circ} \mathrm{N}$, $-4.67455^{\circ} \mathrm{W} ; 240 \mathrm{~m}$ a.s.l.; 6.VIII.2018; same collectors as for preceding; in a cavity of tree; hand capture $\bullet 40^{7}$ (SVL 32.8-35.0 mm), 3 9 (SVL 41.7-42.7 mm); Koti; $11.38779^{\circ} \mathrm{N},-3.06401^{\circ} \mathrm{W} ; 310 \mathrm{~m}$ a.s.l.; 22.VIII.2018; H. J. Ayoro leg.; near a bean field; hand capture - $30^{\text {'; }}$ Kou Forest, on the bank of Kou River in the savannah part; $11.18815^{\circ} \mathrm{N},-4.44397^{\circ} \mathrm{W} ; 375$ m a.s.l.; 9.VIII.2018; H. J. Ayoro \& A. Ohler leg.; in a bush on the river bank; acoustic report $-20^{\top}$; Koubri, around "Ancien barrage"; $12.22828^{\circ} \mathrm{N},-1.34587^{\circ} \mathrm{W}$; $320 \mathrm{~m}$ a.s.l.; 16.VII.2017; same collectors as for preceding; acoustic report $\bullet$ Ioba province, near Dissin; $10.94250^{\circ} \mathrm{N},-3.15778^{\circ} \mathrm{W}$; 260 m a.s.l.; 2011; J. Penner leg.; field direct observation.

LiTERATURE REPORTS. - Burkina Faso - Gourma province, Fada $\mathrm{N}^{\prime}$ gourma; $12.06051^{\circ} \mathrm{N}, 0.34913^{\circ} \mathrm{E} ; 300 \mathrm{~m}$ a.s.l.; 1983 , I-III.2008 (Böhme et al. 1996; Mohneke et al. 2011) • Ganzourgou province, Mogtedo; $12.31844^{\circ} \mathrm{N},-0.83601^{\circ} \mathrm{W} ; 280 \mathrm{~m}$ a.s.l. (Mohneke 2011; Mohneke et al. 2011); • Zorgho; $12.2483^{\circ} \mathrm{N},-0.6278^{\circ} \mathrm{W} ; 300 \mathrm{~m}$ a.s.l.; I-III.2008 (Mohneke 2011; Mohneke et al. 2011).

DesCription. - 29 specimens examined. According to Schiøtz (1999) and Rödel (2000), SVL of this species ranging from 29$40.5 \mathrm{~mm}$ in both sexes. In the observed specimens, males measure 29.8-35.5 $\mathrm{mm}$ and females 31.4-42.7 mm SVL. The back of living specimens of a light green-olive colouration with scattered larger and smaller darker spots (Fig. 5A). 
HaвiтAт. - This species calls at night from holes at the base of shrubs. After rain these frogs may be found moving on the open ground, between grasses and bushes during the night. This species was not found in Dori and Yakouta in the Sahel region of Burkina Faso. It is a common West African savannah species, with a distribution ranging from southern Senegal to western Nigeria (Böhme et al. 1996; Schiøtz 1999; Rödel 2000; Nago et al. 2006; Segniagbeto et al. 2007).

\section{Kassina senegalensis (Duméril \& Bibron, 1841)}

(Fig. 5B, C)

Collection material. - Burkina Faso - $20^{\prime \prime}$ (SVL 31.5 $34.0 \mathrm{~mm}$ ); Kourweogo province, Laye; $12.53079^{\circ} \mathrm{N},-1.77155^{\circ} \mathrm{W}$ 290 m a.s.l.; VIII.1966; M. Lamotte leg.; MNHN-RA-1998.2009, 1998.2010

FIELD MATERIAL. - Burkina Faso • $10^{\prime \prime}($ SVL $31.3 \mathrm{~mm})$; W National Park, on the edge of the PK-27 bouli; $11.88744^{\circ} \mathrm{N}, 2.11913^{\circ} \mathrm{W}$ $265 \mathrm{~m}$ a.s.l.; 20.VI.2018; H. J. Ayoro leg.; under shrubs; hand capture $10^{*}($ SVL $32.2 \mathrm{~mm})$; Comoé-Léraba Forest; $9.93239^{\circ} \mathrm{N}$, $-4.60655^{\circ} \mathrm{W} ; 220 \mathrm{~m}$ a.s.1.; 5.VIII.2018; H. J. Ayoro \& A. Ohler leg.; under grasses; hand capture $44 \mathrm{O}^{7}$ (SVL 34.9-39.4 mm), 3 subadults (SVL 20.6-22.4mm); Dori, Toroodi (near the road from Dori to Ouagadougou); $14.00385^{\circ} \mathrm{N},-0.02411^{\circ} \mathrm{W} ; 270 \mathrm{~m}$ a.s.l.; 24.VIII.2018; H. J. Ayoro leg.; in small holes and in dried footprints of oxen near a water body; hand capture 1 ㅇ (SVL $32.0 \mathrm{~mm})$, 2 subadults (SVL 24.3-27.6 mm); N'Djomga (on the road from Dori to Gorom-Gorom); $14.0722^{\circ} \mathrm{N},-0.0486^{\circ} \mathrm{W} ; 265 \mathrm{~m}$ a.s.l.; 25.VIII.2018; same collector as for preceding; under a heap of dead grasses in a vegetable garden; hand capture $\bullet 1$ subadult (SVL $22.5 \mathrm{~mm}$ ); Yakouta; $14.06111^{\circ} \mathrm{N},-0.13185^{\circ} \mathrm{W} ; 267 \mathrm{~m}$ a.s.l.; 26.VIII.2018; same collector as for preceding; under a shrub; hand capture $11 \mathrm{O}^{\text {; }}$; Koubri, around "Ancien barrage"; $12.22828^{\circ} \mathrm{N}$, $-1.34587^{\circ} \mathrm{W} ; 320 \mathrm{~m}$ a.s.l; 16.VII.2017; same collector as for preceding; in a bush; acoustic report $120^{\text {* }}$; Arly National Park, floodplain $\left(500 \mathrm{~m}\right.$ north of Bouliabou pond); $11.57852^{\circ} \mathrm{N}$, $1.46004^{\circ} \mathrm{E}$; $255 \mathrm{~m}$ a.s.l.; 16.VI.2018; same collector as for preceding; acoustic report $1 \mathrm{O}^{7}$; Kou Forest; in the savannah part of this Forest; $11.18815^{\circ} \mathrm{N},-4.44397^{\circ} \mathrm{W} ; 375 \mathrm{~m}$ a.s.l.; 9.VIII.2018; H. J. Ayoro \& A. Ohler leg.; in a bush; acoustic report - Dano, Gbagba; $11.18133^{\circ} \mathrm{N},-3.05163^{\circ} \mathrm{W} ; 300 \mathrm{~m}$ a.s.l.; 2011 ; J. Penner leg.; field direct observation.

Literature RePorts. - Burkina Faso - Yako; $12.96744^{\circ} \mathrm{N}$, $-2.26155^{\circ} \mathrm{W} ; 330 \mathrm{~m}$ a.s.l.; 18.VIII.1961 (Schiøtz 1967).

DesCRIPTION. - 15 specimens examined. Males from Laye, Comoé-Léraba forest and W National Park measuring 31.3$34.0 \mathrm{~mm}$ SVL. Males of Dori and Yakouta atteining larger size, 34.9-39.4 $\mathrm{mm}$ SVL. These sizes within the known size range of the species (Lamotte \& Xavier 1981; Schiøtz 1999; Rödel 2000; Channing 2001; Channing \& Howell 2006; Amiet 2012). Dorsal colouration of $K$. senegalensis a light-green, yellow or green olive, usually with three dark longitudinal strips, either thin continuous or broken into dark broad blotches (Fig. 5B, C).

HABITAT. - Kassina senegalensis are fast moving among grasses and shrubs. Two vouchers were collected under bushy grasses from where they called and were difficult to localize. In Dori and Yakouta area, $K$. senegalensis was found on the ground under piles of pebbles near water, as well as in small holes or cattle footprints between grasses close to a pond. We heard other males calling from the base of thorny shrubs and piles of dry grass near a millet field. Kassina senegalensis was also found in Sahelian savannahs in Mauritania (Padial et al. 2013). It shelters under rocks or termite mounds during dry periods (Poynton \& Broadley 1987; Rödel 2000).
Family MiCROHYLIDAE Günther, 1858

\section{Phrynomantis microps Peters, 1875}

(Fig. 5D)

Collection material. - Burkina Faso - $40^{7}$ (SVL 38.2 $38.6 \mathrm{~mm}$ ); Kourweogo province, Laye; $12.53081^{\circ} \mathrm{N},-1.77155^{\circ} \mathrm{W}$; 290 m a.s.l.; VIII.1968; M. Lamotte leg.; MNHN-RA-2000.5667, 2000.5660, 2000.5657, 2000.5659 • 1 ơ (SVL $41.1 \mathrm{~mm})$; Sanemantenga province, Kossoghin; $13.29944^{\circ} \mathrm{N},-1.05088^{\circ} \mathrm{W}$; 320 m a.s.l.; VIII.1966; M. Lamotte leg.; MNHN-RA-1995.7090.

FIELD MATERIAL. - Burkina Faso • $1 \mathrm{o}^{\pi}$ (SVL $38.2 \mathrm{~mm}$ ); Arly National Park, the floodplain; $11.57852^{\circ} \mathrm{N}, 1.46004^{\circ} \mathrm{E} ; 255 \mathrm{~m}$ a.s.l.; 16.VI.2018; H. J. Ayoro leg.; near a small water body; hand capture - 1 ㅇ (SVL $42.5 \mathrm{~mm}$ ); Koti; $11.38788^{\circ} \mathrm{N},-3.06401^{\circ} \mathrm{W} ; 310 \mathrm{~m}$ a.s.l.; 15.IX.2018; same collector as for preceding; in a peanut field; hand capture $10^{7}$ (SVL $\left.42.3 \mathrm{~mm}\right), 1$ ( $(\mathrm{SVL} 51.4 \mathrm{~mm})$; Folonzo village swampy valley; $9.95777^{\circ} \mathrm{N},-4.67455^{\circ} \mathrm{W} ; 240 \mathrm{~m}$ a.s.l.; 6.VIII.2018; H. J. Ayoro \& A. Ohler leg.; anthill and scorpion's holes; hand capture $2 \mathrm{O}^{7}$; on the edge of Pabré dam; $12.51597^{\circ} \mathrm{N}$, $-1.59923^{\circ} \mathrm{W} ; 290 \mathrm{~m}$ a.s.l.; 11-12.VII.2017; same collectors as for preceding; under the trees near the dam; acoustic report - $1 \mathrm{O}^{7}$; near the "Ancien barrage"; $12.22843^{\circ} \mathrm{N},-1.34766^{\circ} \mathrm{W}$; $285 \mathrm{~m}$ a.s.1.; 16.VII.2017; same collectors as for preceding; acoustic report $10^{\text {" }}$; in the Koubri monaster reserve around the Monastery Hostel; $12.21687^{\circ} \mathrm{N},-1.35048^{\circ} \mathrm{W} ; 280 \mathrm{~m}$ a.s.l.; 17.VII.2017; same collectors as for preceding; acoustic report $\bullet 10^{\text {; }}$; W National Park, near PK-27 bouli; $11.88744^{\circ} \mathrm{N}, 2.11913^{\circ} \mathrm{W}$; 265 m a.s.l.; 20.VI.2018; H. J. Ayoro leg.; acoustic report $110^{\prime 7}$; the Kabougou village swampy valley; $11.96075^{\circ} \mathrm{N}, 1.99744^{\circ} \mathrm{E}$; $280 \mathrm{~m}$ a.s.l.; 22.VI.2018; same collector as for preceding; near paddy field; acoustic report $\bullet 3 \mathrm{O}^{\text {; }}$; Kou Forest; $11.18888^{\circ} \mathrm{N}$, $-4.43944^{\circ} \mathrm{W} ; 260 \mathrm{~m}$ a.s.l.; 7-9.VIII.2018; H. J. Ayoro \& A. Ohler leg.; in the savannah part and at the edge of this forest; acoustic report - Ioba province, Djikologo (close to Bontioli reserve); $10.94253^{\circ} \mathrm{N},-3.15788^{\circ} \mathrm{W} ; 260 \mathrm{~m}$ a.s.l.; J. Penner leg. • Dano, Gbagba; $11.18133^{\circ} \mathrm{N},-3.05159^{\circ} \mathrm{W} ; 300 \mathrm{~m}$ a.s.l.; 2011 ; J. Penner leg.; field direct observation.

Literature REPORTS. - Burkina Faso - Yako; $12.96744^{\circ} \mathrm{N}$, $-2.26155^{\circ} \mathrm{W} ; 330 \mathrm{~m}$ a.s.l.; 18.VIII.1961 (Schiøtz 1967) • Gourma province, Fada N'gourma; $12.06051^{\circ} \mathrm{N}, 0.34913^{\circ} \mathrm{E} ; 300 \mathrm{~m}$ a.s.l.; 1983, I-III.2008 (Böhme et al. 1996; Mohneke et al. 2011) - Ganzourgou province, Mogtedo; $12.31844^{\circ} \mathrm{N},-0.83601^{\circ} \mathrm{W}$; $280 \mathrm{~m}$ a.s.l. (Mohneke 2011; Mohneke et al. 2011) • Zorgho; $12.2483^{\circ} \mathrm{N},-0.6278^{\circ} \mathrm{W} ; 300 \mathrm{~m}$ a.s.l.; I-III.2008 (Mohneke 2011; Mohneke et al. 2011).

DesCription. - 9 specimens examined. Size within the range given by Rödel (2000). Characterized by a unique body shape and a red back (Fig. 5D). Presence of a fine dark brown vertebral line on the back. In alcohol, the red colouration getting a greyish.

HABiтAT. - The species calls often below shrubs and from holes. In Comoé-Léraba Forest, males were collected in shrubs on the edge of a large dark scorpion hole where they were calling. It was also found on the edge of water under a tree. A female was found on an anthill ready to withdraw into a hole. The species has been reported to often occur within ant nests and scorpion burrows (Rödel \& Braun 1999; Rödel et al. 2013).

It is known that $P$. microps colonizes various savannah habitats including dense tree savannah where it is found in flooded meadows, in ponds and swamps (Schiøtz 1967; Rödel 2000; Hirschfeld \& Rödel 2011). Barej et al. (2017) reported its occurence in West and Central Africa. 

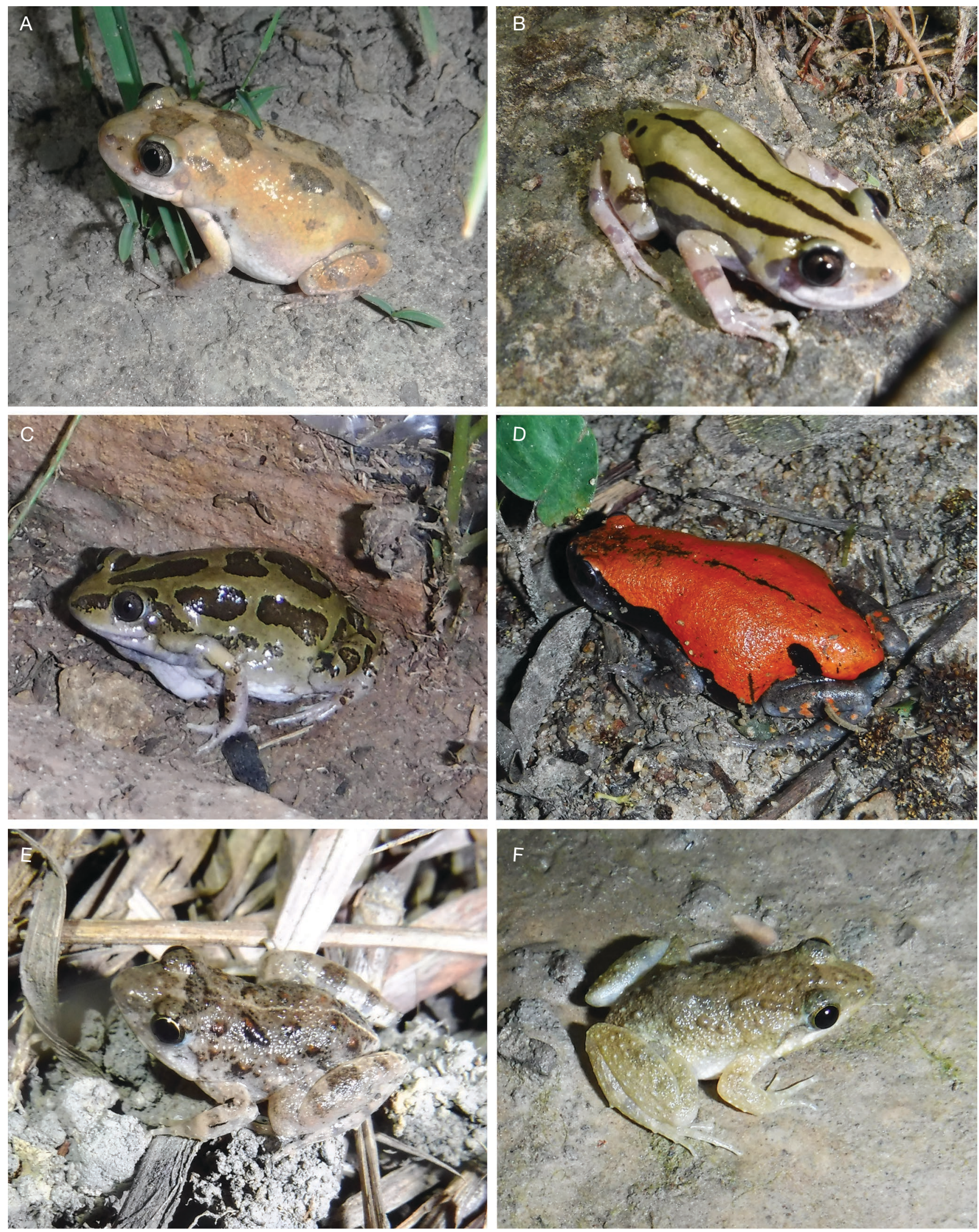

FiG. 5. - Representatives of anuran species from Burkina Faso in life. A, Kassina fusca Schiøtz, 1967; B-C, Kassina senegalensis (Duméril \& Bibron, 1841); D, Phrynomantis microps Peters, 1875; E, Phrynobatrachus francisci Boulenger, 1912; F, Phrynobatrachus latifrons Ahl, 1924. Photos: Halamoussa Joëlle Ayoro. 
Family PHRYNOBATRACHIDAE Laurent, 1941

\section{Phrynobatrachus francisci Boulenger, 1912} (Fig. 5E)

Collection MATERIAL. - Burkina Faso - $10^{7}$ (SVL $\left.16.1 \mathrm{~mm}\right)$, 1 ㅇ (SVL $22.8 \mathrm{~mm}$ ), 1 subadult (SVL $14.6 \mathrm{~mm}$ ); Léraba province, Loumana; $10.58001^{\circ} \mathrm{N},-5.35044^{\circ} \mathrm{W} ; 330 \mathrm{~m}$ a.s.l.; XI.1970; J.-J. Morère \& M. Lamotte leg.; MNHN-RA-1996.8753, 1996.8750, $1999.7505 \bullet 20^{7}$ (SVL 18-18.3 mm), 7 9 (SVL 20.2-23 mm); Samba; $12.70145^{\circ} \mathrm{N},-2.40388^{\circ} \mathrm{W} ; 290 \mathrm{~m}$ a.s.l.; 13.VII.1962; M. Lamotte leg.; MNHN-RA-2007.0598, 2007.0599, 2007.0600, 2007.0601, 2007.0602, 2007.0603, 2007.0604, 2007.0605, 2007.0606• 6 subadults (SVL 14-15.8 mm); Tapoa province, Arly; $11.57975^{\circ} \mathrm{N}$, $1.47072^{\circ} \mathrm{W} ; 175 \mathrm{~m}$ a.s.l.; 27.XII.1972; M. Lamotte leg.; MNHNRA-2001.1371, 2001.1372, 2001.1373, 2001.1374, 2001.1375, $2001.1376 \bullet 30^{7}$ (SVL 18.1-20.3 mm), 1 9 (SVL $16.9 \mathrm{~mm}$ ), $2 \mathrm{sub}-$ adults (SVL 14.3-15.6 mm); Bazèga province, at $40 \mathrm{~km}$ south of Ouagadougou; $12.38011^{\circ} \mathrm{N}, 1.51100^{\circ} \mathrm{W} ; 350 \mathrm{~m}$ a.s.l.; XII.1965; T. J. Papenfuss leg.; MVZ 82791, MVZ 82794-98.

FIELD MATERIAL. - Burkina Faso - 5 ơ (SVL 20.1-22.6 mm); Pabré dam; $12.51159^{\circ} \mathrm{N},-1.58833^{\circ} \mathrm{W} ; 290 \mathrm{~m}$ a.s.l.; 10. VII.2017; H. J. Ayoro \& A. Ohler leg.; in an irrigation ditch; hand capture - 2 O' $^{\prime \prime}$ (SVL 22.2-24.5 mm), 1 ㅇ (SVL $23.4 \mathrm{~mm}$ ), 5 subadults; Deux Balés National Park, close to Ouahabou bouli; $11.60765^{\circ} \mathrm{N}$, $-3.06033^{\circ} \mathrm{W} ; 260 \mathrm{~m}$ a.s.l.; 8.XI.2017; H. J. Ayoro leg.; around water body; hand capture $\bullet 3 \mathrm{O}^{7}$ (SVL 20.0-22.5 mm), 2 subadults (SVL 15.6-17.5 mm); Deux Balés National Park, the edge of Pampara pond; $11.65613^{\circ} \mathrm{N},-3.0303234^{\circ} \mathrm{W} ; 270 \mathrm{~m}$ a.s.l.; 8.XI.2017; same collector as for preceding; around water body; hand capture - $10^{\pi}$ (SVL $18.1 \mathrm{~mm}$ ), 4 subadults (SVL 15.0-16.2 mm); Deux Balés National Park, downstream of Soumbou dam; $11.69872^{\circ} \mathrm{N}$, $-2.79738^{\circ} \mathrm{W} ; 260 \mathrm{~m}$ a.s.1.; 8.XI.2017; same collector as for preceding; on dry grasses near water body; hand capture $30^{7}$ (SVL 22.3$23.3 \mathrm{~mm}$ ), 3 ㅇ (SVL 22.1-23.0 mm); Deux Balés National Park, the edge of Petit Balé dam; $11.59998^{\circ} \mathrm{N},-2.92701^{\circ} \mathrm{W} ; 240 \mathrm{~m}$ a.s.l.; 9.XI.2017; same collector as for preceding; in the cavities of lateritic stones near water body; hand capture $\bullet 7 \mathrm{o}^{\circ}$ (SVL 18.5-23.5 mm), 5 o (SVL 18.52-0.8 mm), 3 subadults (SVL 15.5-16.8 mm); Deux Balés National Park, the edge of Kohéna pond; $11.67665^{\circ} \mathrm{N},-2.83611^{\circ} \mathrm{W}$ $275 \mathrm{~m}$ a.s.l.; 9.XI.2017; same collector as for preceding; on the mud around water body; hand capture 1 \% (SVL $21.3 \mathrm{~mm}$ ); Arly National Park, Bouliabou pond; $11.57892^{\circ} \mathrm{N}, 1.46388^{\circ} \mathrm{E} ; 170 \mathrm{~m}$ a.s.l.; 11.VI.2018; same collector as for preceding; near water body; hand capture $11 \mathrm{O}^{\text {त }}$ (SVL $22.2 \mathrm{~mm}$ ), 1 \% (SVL $23.5 \mathrm{~mm}$ ); the bank of Arly River; $11.55946^{\circ} \mathrm{N}, 1.45624^{\circ} \mathrm{E} ; 170 \mathrm{~m}$ a.s.l.; 14.VI.2018; same collector as for preceding; under dead wood near water body; hand capture $\bullet 30^{\prime \prime}$ (SVL 18.4-21.2 mm); Kabougou River; $11.96860^{\circ} \mathrm{N}$, $2.01259^{\circ} \mathrm{E} ; 280$ m.a.s.l; 18 .VI.2018; same collector as for preceding; in a paddy field; hand capture $110^{\text {T }}$ (SVL $22.9 \mathrm{~mm}$ ), 3 9 (SVL 22.2-23.7 mm); near the protected part of Kabougou River; $11.97060^{\circ} \mathrm{N}, 2.01626^{\circ} \mathrm{E} ; 265 \mathrm{~m}$ a.s.l.; 19.VI.2018; same collector as for preceding; on dead leaves; hand capture • $40^{\text {" }}$ (SVL 18.6$22.7 \mathrm{~mm}$ ), 1 \% (SVL $22.9 \mathrm{~mm}$ ); W National Park, on the edge of PK-27 bouli; $11.88744^{\circ} \mathrm{N}, 2.11913^{\circ} \mathrm{W} ; 265 \mathrm{~m}$ a.s.l.; 20.VI.2018; same collector as for preceding; on the mud near water body; hand capture 10 subadults; the edge of PK-27 bouli; 3.II.2017; same collector as for preceding; on the mud near water body; visual observation • $10^{7}$ (SVL $21.5 \mathrm{~mm}$ ), 1 ㅇ (SLV $22.5 \mathrm{~mm}$ ); Baboro swampy valley; $9.92509^{\circ} \mathrm{N},-4.57577^{\circ} \mathrm{W} ; 240 \mathrm{~m}$ a.s.l.; 4.VIII.2018; H. J. Ayoro \& A. Ohler leg.; near water body; hand capture $\bullet 1$ ㅇ (SVL $21.4 \mathrm{~mm}$ ); the flood zone of Comoé River (300 m west of the Comoé bridge); $9.93239^{\circ} \mathrm{N},-4.60655^{\circ} \mathrm{W} ; 220 \mathrm{~m}$ a.s.l.; 5.VIII.2018; same collectors as for preceding; near small water body; hand capture $\cdot 7$ \% (SVL 18.4-23.5 mm); Folonzo village swampy valley; $9.95775^{\circ} \mathrm{N},-4.67449^{\circ} \mathrm{W} ; 245 \mathrm{~m}$ a.s.l.; 6.VIII.2018; same collectors as for preceding; near a small water body; hand capture $\bullet 2$ subadults (SVL 12.0-13.1 mm); N'Djomga village pond; $14.07225^{\circ} \mathrm{N},-0.04862^{\circ} \mathrm{W} ; 270 \mathrm{~m}$ a.s.l.; 25.VIII.2018; H. J. Ayoro leg.; on the mud surrounding the pond; hand capture - 1 (SVL $21.2 \mathrm{~mm}$ ); Dori, Toroodi; $14.00606^{\circ} \mathrm{N},-0.02846^{\circ} \mathrm{W}$; $280 \mathrm{~m}$ a.s.l.; 27.VIII.2018; same collector as for preceding; under small grasses; hand capture $120^{7}$; Dédougou, SONATUR city (the way from Dédougou to Toughan); $12.48972^{\circ} \mathrm{N},-3.43611^{\circ} \mathrm{W}$; $300 \mathrm{~m}$ a.s.l.; 22.VIII.2017; same collector as for preceding; under submerged grasses near small rubbish dump; visual observation and acoustic report $\bullet$ Ioba province, Dano; $11.16600^{\circ} \mathrm{N},-3.08689^{\circ} \mathrm{W}$; $340 \mathrm{~m}$ a.s.l.; 2011; J. Penner leg.; field observation.

Literature REPORTS. - Burkina Faso - Yako; $12.96744^{\circ} \mathrm{N}$, $-2.26155^{\circ} \mathrm{W} ; 330 \mathrm{~m}$ a.s.l.; 18.VIII.1961 (Schiøtz 1967) • Comoé province, near Kafolo; coordinates not available; 11.VI.1992 (Böhme et al. 1996) - Houet province, Koro; $11.14433^{\circ} \mathrm{N},-4.19888^{\circ} \mathrm{W}$; 350 m a.s.l.; 14.VI.1992 (Böhme et al. 1996) • Houet province, Daroha; coordinates not available; 14.VI.1992 (Böhme et al. 1996).

DESCRIPTION. - 96 specimens examined. Our vouchers within the known size range given by Rödel (2000). A small, warty frog with a short and rounded snout. Presence of one or two pairs of chevron shaped warts on the neck (Fig. 5E). Colour of P. francisci usually brown to grey. Males with a dark vocal sac.

Habitat. - Phrynobatrachus francisci is restricted to humid habitats and is abundant in all seasons close to water. During the dry season, we collected these frogs on the edge of ponds and rivers, under pebbles and rocks (Fig. 2A, B). It is also found near wells, fountains and cattle troughs. This species has a wide distribution in drier savannahs of West Africa (Rödel 2000; Onadeko 2016).

\section{Phrynobatrachus latifrons Ahl, 1924 (Fig. 5F)}

Collection MATERial. - Burkina Faso • $10^{7}$ (SVL $16.3 \mathrm{~mm}$ ); Comoé province, Dérégoué; $10.75011^{\circ} \mathrm{N},-4.07934^{\circ} \mathrm{W} ; 320 \mathrm{~m}$ a.s.l.; II.1983; J. Heath leg.; ZFMK 93966.

Field MATERIAL. - Burkina Faso • $10^{\text {"7 }}$ (SVL 16.5 mm); Pabré dam; $12.51159^{\circ} \mathrm{N},-1.58833^{\circ} \mathrm{W} ; 290 \mathrm{~m}$ a.s.l.; 10.VII.2017; H. J. Ayoro \& A. Ohler leg.; in an irrigation ditch; hand capture - 6 ơ $^{7}$ (SVL 16.1-19.5 mm); Koubri, downstream from Nabazana dam; $12.20319^{\circ} \mathrm{N},-1.35105^{\circ} \mathrm{W} ; 280 \mathrm{~m}$ a.s.l.; $17 . V I I .2017$; same collectors as for preceding; under a heap of dry grasses near paddy field; hand capture $20^{7}$ (SVL 17.8-18.8 mm); Deux Balés National Park, the edge of Ouahabou bouli; $11.60765^{\circ} \mathrm{N},-3.06033^{\circ} \mathrm{W}$; $260 \mathrm{~m}$ a.s.l.; 8.XI.2017; H. J. Ayoro leg.; around water body; hand capture $220^{7}$ (SVL 19.5-20.3 mm); Deux Balés National Park, the edge of Kohéna pond; $11.67665^{\circ} \mathrm{N},-2.83611^{\circ} \mathrm{W} ; 275 \mathrm{~m}$ a.s.l.; 9.XI.2017; same collector as for preceding; on the mud around water body; hand capture 11 subadult (SVL $13.4 \mathrm{~mm}$ ); W National Park, the bank of Mékrou River (close to the Beninese border, near the Point Triple Residence); $11.89991^{\circ} \mathrm{N}, 2.40265^{\circ} \mathrm{E}$; $240 \mathrm{~m}$ a.s.l.; 4.II.2017; same collector as for preceding; under a stone near water body, hand capture • $60^{7}$ (SVL 16.9-18.1 mm), 7 (SVL 19.0-22.2 mm); Arly National Park, the edge of Bouliabou pond; $11.57892^{\circ} \mathrm{N}, 1.46388^{\circ} \mathrm{E} ; 170 \mathrm{~m}$ a.s.l.; 11.VI.2018; same collector as for preceding; around water body; hand capture $20^{\prime \prime}$ (SVL 17.9-22.1 mm), 1 (SVL $22.2 \mathrm{~mm}$ ); the bank of Arly River, $500 \mathrm{~m}$ north-east of the central forest post office; $11.57845^{\circ} \mathrm{N}$, $1.46146^{\circ} \mathrm{E} ; 170 \mathrm{~m}$ a.s.l.; 12 .VI.2018; same collector as for preceding; under dead wood; hand capture $\bullet 20^{\prime \prime}$ (SVL 17.6-17.8 mm), 3 (SVL 19.0-21.0 mm); the bank of Arly River; $1 \mathrm{~km}$ west of the central forest post office; $11.57048^{\circ} \mathrm{N}, 1.45218^{\circ} \mathrm{E} ; 160 \mathrm{~m}$ a.s.l.; 15.VI.2018; same collector as for preceding; near water body; hand capture $10^{\prime \prime}$ (SVL $\left.18.8 \mathrm{~mm}\right), 2$ (SVL 18.1-21.9 mm); the floodplain, $500 \mathrm{~m}$ north of Bouliabou pond; $11.57852^{\circ} \mathrm{N}, 1.46004^{\circ} \mathrm{E}$; 
$255 \mathrm{~m}$ a.s.l.; 16.VI.2018; same collector as for preceding; near water body; hand capture 1 \% (SVL $23.3 \mathrm{~mm}$ ); Comoé-Léraba Forest, Baboro swampy valley; $9.92509^{\circ} \mathrm{N},-4.57577^{\circ} \mathrm{W} ; 240 \mathrm{~m}$ a.s.l.; 4.VIII.2018; H. J. Ayoro \& A. Ohler leg.; in open space; hand capture $110^{7}$ (SVL $18.7 \mathrm{~mm}$ ); the flooded area of Comoé River; $9.93239^{\circ} \mathrm{N},-4.60655^{\circ} \mathrm{W} ; 220 \mathrm{~m}$ a.s.l.; 5.VIII.2018; same collectors as for preceding; on a shrub; hand capture.

DESCRIPTION. - 39 specimens examined. Voucher specimens morphologically similar to frogs described by Rödel (2000). Similar to $P$. francisci but the warts on the neck often less distinct in P. latifrons. Breeding males with a completely smooth skin (Fig. 5F), (Rödel 2000). A yellow vocal sac in males (black in $P$. francisci) and a more pronounced black lateral bands distinguishing $P$. latifrons from $P$. francisci.

HABITAT. - This species was found on mud under dead wood and rocks at the edge of ponds in the dry season (Fig. 2A, B). During the rainy season, the species always lives close to water and we collected them on submerged grasses, under shrubs on the edge of little water bodies. Phrynobatrachus latifrons lives in tree and open savannahs, farm bush and agricultural areas. It avoids closed primary rainforest, but may be found in degraded rainforest (Rödel 2000; Kpan et al. 2014; Onadeko 2016; Rödel \& Glos 2019).

\section{Family PIPIDAE Gray, 1825}

\section{Xenopus fischbergi Evans et al., 2015}

COllection MATERIAL. - Burkina Faso - 11 tadpoles; Banfora; $10.64800^{\circ} \mathrm{N},-4.77679^{\circ} \mathrm{W} ; 280 \mathrm{~m}$ a.s.l.; XII.1959; M. Lamotte leg.; MNHN-RA-1993.4057, 1993.4058, 1993.4059, 1993.4060, 1993.4061, 1993.4062, 1993.4063, 1993.4064, 1993.4065 , 1993.4066, 1993.4067 • 8 ㅇ (SVL 39.5-45.3 mm); Boulgou province, Garango; $11.79982^{\circ} \mathrm{N},-0.55055^{\circ} \mathrm{W} ; 280$ m a.s.l.; $18 . V I .1962 ; \mathrm{M}$. Lamontellerie leg.; MNHN-RA-1993.4376, 1993.4377, 1993.4378, 1993.4379, 1993.4380, 1993.4381, 1993.4382, 1993.4383 • 3 subadults (SVL 34-36.8 mm), 1 \% (SVL $45.1 \mathrm{~mm}$ ); Bobo-Dioulasso, Pala; $11.14978^{\circ} \mathrm{N},-4.22275^{\circ} \mathrm{W} ; 280 \mathrm{~m}$ a.s.l.; XII.1970; M. Lamotte leg.; MNHN-RA-1997.0886, 1997.0887, 1997.0888, 1997.0889.

FIELD MATERIAL. - Burkina Faso • 3 ㅇ (SVL 39.9-47.7 mm); Koti; $11.38788^{\circ} \mathrm{N},-3.06401^{\circ} \mathrm{W} ; 310 \mathrm{~m}$ a.s.l.; $10 . X .2017$; H. J. Ayoro leg.; in a small water near a garbage dump; hand capture $\bullet 1 \%$ (SVL $40.7 \mathrm{~mm}$ ); same locality; 27.IX.2018; same collector as for preceding; in a small pond in a bush; hand capture 2 \% (SVL 45.1 $46.8 \mathrm{~mm}$ ), 2 subadults (SVL 34.3-37.1 mm); Loumbila, downstream from the Loumbila dam; $12.491656^{\circ} \mathrm{N},-1.40244^{\circ} \mathrm{W}$ $280 \mathrm{~m}$ a.s.l.; 14.VII.2017; H. J. Ayoro \& A. Ohler leg.; in an irrigated well; hand capture $\bullet 4$ (SVL $41.7-58.5 \mathrm{~mm}), 4$ subadults (SVL 23.5-36.7 mm); Tuy province, Fafo; $11.33470^{\circ} \mathrm{N},-3.01947^{\circ} \mathrm{W}$; $300 \mathrm{~m}$ a.s.l.; 5.XI.2018; H. J. Ayoro leg.; in the backwater of Fafo; hand capture $\bullet 2$ individuals; Ouagadougou, University of Joseph Ki-Zerbo; $12.378350^{\circ} \mathrm{N},-1.50128^{\circ} \mathrm{W} ; 295 \mathrm{~m}$ a.s.l.; 12 .VIII.2018; same collector as for preceding; in the water of the channel near the university restaurant; visual observation.

LITERATURE REPORTS. - Burkina Faso • Banfora; $10.64800^{\circ} \mathrm{N}$ $-4.77679^{\circ} \mathrm{W} ; 280 \mathrm{~m}$ a.s.l.; Yako; $12.96744^{\circ} \mathrm{N},-2.26155^{\circ} \mathrm{W} ; 330 \mathrm{~m}$ a.s.l. (Loumont 1984$) \bullet$ Fada N'gourma; $12.06051^{\circ} \mathrm{N}, 0.34913^{\circ} \mathrm{E}$; $300 \mathrm{~m}$ a.s.l. (Mohneke 2011; Mohneke et al. 2011) • Mogtedo; $12.31844^{\circ} \mathrm{N},-0.83601^{\circ} \mathrm{W} ; 280 \mathrm{~m}$ a.s.l. (Mohneke 2011; Mohneke et al. 2011) - Zorgho; $12.2483^{\circ} \mathrm{N},-0.6278^{\circ} \mathrm{W} ; 300 \mathrm{~m}$ a.s.l.; I-III.2008 (Mohneke 2011; Mohneke et al. 2011).

DESCRIPTION. - 39 specimens examined. Adult and subadult specimens of Xenopus fischbergi with flat head and smooth body. Presence of a long subocular tentacle and three black claws on toes. In alcohol, the back and limbs greyish to brown with few darker brown spots. The belly whitish, some darker spots occasionally on the throat and on the thighs; whitish zones usually yellow in life. Previous West African reports of this species under the name Xenopus muelleri.

Habitat. - We collected $X$. fischbergi in the water of irrigation wells, in plantain fields in Loumbila and in a small water body in Koti. These habitats were surrounded by grasses and had aquatic plants. During the dry season, X. fischbergi was found at the banks of rivers in savannah habitats (Schiøtz 1967; Böhme et al. 1996). It is known from various other West African countries such as Benin, Ghana, Ivory Coast, Nigeria and Togo (Rödel 2000; Nago et al. 2006; Segniagbeto et al. 2007; Onadeko 2016).

\section{Xenopus tropicalis (Gray, 1864)}

COllection MATERIAL. - Burkina Faso • 7 9 (SVL 34.5-55 mm), 9 subadults (SVL 23.2-32.9 mm); Houet province, Bobo-Dioulasso; $11.14979^{\circ} \mathrm{N},-4.22272^{\circ} \mathrm{W} ; 280 \mathrm{~m}$ a.s.l.; II.1983; NA leg.; ZFMK 38659-65, 38688-96.

Field Material. - Burkina Faso $10^{\text {; }}$; Arly National Park, the floodplain; $11.57852^{\circ} \mathrm{N}, 1.46004^{\circ} \mathrm{E} ; 255 \mathrm{~m}$ a.s.l.; $16 . V I .2018$; H. J. Ayoro leg.; in water body; acoustic report 11 \% (SVL $41.2 \mathrm{~mm}$ ); Kou Forest; $11.18885^{\circ} \mathrm{N},-4.43938^{\circ} \mathrm{W} ; 320$ m a.s.l.; 8.VIII.2018; H. J. Ayoro \& A. Ohler leg.; in the water of a concrete basin; hand capture $\bullet$ Dano, Dano dam; $11.16462^{\circ} \mathrm{N},-3.08633^{\circ} \mathrm{W} ; 340 \mathrm{~m}$ a.s.l.; 2011; J. Penner leg.; field direct observation.

Literature RePORTS. - Burkina Faso - Houet province, Bobo-Dioulasso; $11.18800^{\circ} \mathrm{N},-4.29744^{\circ} \mathrm{W} ; 420 \mathrm{~m}$ a.s.l.; 1983 (Böhme et al. 1996) • Comoé province, $4 \mathrm{~km}$ north-east of Dérégoué; $10.75013^{\circ} \mathrm{N},-4.07932^{\circ} \mathrm{W} ; 320 \mathrm{~m}$ a.s.l.; 1985 (Böhme \& Heath 2018).

DESCRIPTION. - 17 specimens studied. A rare species in our studies sites. This typical pipid shaped frog distinguished from Xenopus fischbergi by the inner metatarsal tubercles covered by a dark keratinized tip forming a fourth claw.

HaвiтAт. - Our single collected $X$. tropicalis was captured in the water of a concrete basin beside a bridge at Kou River. It was within the gallery forest of this river. In Arly National Park, a male was calling under flooded trees near the Arly River. The species is widespread in rainforests in West Africa. It ranges further north along gallery forests. Its presence was reported from many western African countries, ranging from Senegal to Cameroon (Rödel 2000; Segniagbeto $e t$ al. 2007; Onadeko \& Rödel 2009; Kouamé et al. 2014; Kpan et al. 2014; Evans et al. 2015; Onadeko 2016; Rödel \& Glos 2019).

Family PTyChadenidae Dubois, 1987

Hildebrandtia ornata (Peters, 1878)

(Fig. 6A)

COllection MATERIAL. - Burkina Faso • $10^{7}$ (SVL 58.7 mm), 2 ㅇ (SVL 56.5-57.0 mm), 1 juvenile (SVL $17.8 \mathrm{~mm}$ ); Passoré province, Samba; $12.70144^{\circ} \mathrm{N},-2.40391^{\circ} \mathrm{W} ; 290 \mathrm{~m}$ a.s.l.; 13.VII.1962; M. Lamotte / Père Terrible leg.; MNHN-RA-2006.2859, 2006.2860, 1995.5755, 2006.2858.

FIELD MATERIAL. - Burkina Faso • 5 juveniles (SVL 19.0-22.8 mm), 1 subadult (SVL $38.8 \mathrm{~mm}$ ); W National Park, Kabougou River; $11.96860^{\circ} \mathrm{N}, 2.01259^{\circ} \mathrm{E} ; 280$ m.a.s.l; 18-20.VI.2018; H. J. Ayoro leg.; around paddy field; hand capture $\bullet 1$ subadult (SVL $37.8 \mathrm{~mm}$ ), 
$1 \mathrm{O}^{7}$; Folonzo village swampy valley; $9.95777^{\circ} \mathrm{N},-4.67455^{\circ} \mathrm{W}$ $240 \mathrm{~m}$ a.s.l.; 6.VIII.2018; H. J. Ayoro \& A. Ohler leg.; on the edge of the water body; hand capture and acoustic report $-5 \%(54.1$ $61.9 \mathrm{~mm}$ ), 18 subadults (SVL 33.0-45.9 mm); Koti; $11.38788^{\circ} \mathrm{N}$, $-3.06401^{\circ} \mathrm{W} ; 310 \mathrm{~m}$ a.s.l.; 24.VIII.2018; H. J. Ayoro leg.; on the edge of a groundnut field; hand capture 1 individual; Pabré, "Hotel le Repère"; $12.53261^{\circ} \mathrm{N},-1.58286^{\circ} \mathrm{W} ; 310 \mathrm{~m}$ a.s.l.; $11 . V I I .2017$; H. J. Ayoro \& A. Ohler leg.; in a swimming pool; visual observation $10^{7}$; Arly National Park, on the floodplain; $11.57852^{\circ} \mathrm{N}$, $1.46004^{\circ} \mathrm{E} ; 255 \mathrm{~m}$ a.s.l.; 16.VI.2018; under grasses on the edge of small water body; visual and acoustic report.

LiterATURE REPORTS. - Burkina Faso • Gourma province, Fada N'gourma; $12.06051^{\circ} \mathrm{N}, 0.34913^{\circ} \mathrm{E} ; 300 \mathrm{~m}$ a.s.l. (Mohneke 2011 ; Mohneke et al. 2011) • Ganzourgou province, Mogtedo; $12.31844^{\circ} \mathrm{N}$, $-0.83601^{\circ} \mathrm{W} ; 280 \mathrm{~m}$ a.s.l.; (Mohneke 2011; Mohneke et al. 2011) - Zorgho; $12.2483^{\circ} \mathrm{N},-0.6278^{\circ} \mathrm{W} ; 300 \mathrm{~m}$ a.s.I.; I-III.2008 (Mohneke 2011; Mohneke et al. 2011).

DESCRIPTION. - 34 specimens examined. Large frog with stocky body and short head, presence of a characteristic colour pattern with a green broad middorsal band, often split by a series of discontinous brown stripes, sides of dorsum dark brown with a greenish brown band on flanks from tympanic region to groin; $y$-shaped white stripes on the black throat (Fig. 6A).

HABITAT. - Hildebrandtia ornata was collected on garbage dumps filled after rainfalls on Kabougou River banks (W National Park). We found it as well under deadwood on the edge of a groundnut field in Koti. At Pabré, it was seen in a swimming pool in the hostel court. We saw a calling male between grasses in Arly National Park. The frog is a fossorial species which emerges only temporarily during the breeding season (Nago et al. 2006; Mohneke et al. 2010a). It occurs in dry and more humid savannahs and it is absent from forest pockets and very rocky terrain within its range (Rödel 2000; Böhme \& Heath 2018). It maintains in disturbed habitats.

\section{Ptychadena bibroni (Hallowell, 1845)}

COllection MATERIAL. - Burkina Faso • 4 subadults (SVL 29.8$33.9 \mathrm{~mm}$ a.s.l.); Houet province, Bobo-Dioulasso; $11.18801^{\circ} \mathrm{N}$, $-4.29744^{\circ} \mathrm{W} ; 280 \mathrm{~m}$ a.s.l.; 6.XI.1966; M. Lamotte leg.; MNHNRA-1996.8731, 1996.8732, 1996.8733, 1996.8734 • 1 ㅇ (SVL $35.6 \mathrm{~mm}$ ); Bobo-Dioulasso; 31.X.1970; M. Lamotte leg.; MNHN-RA-1996.607 • 2 subadults (SVL 22.3-24.4 mm); Nasso; 11.2095 $4^{\circ} \mathrm{N},-4.43953^{\circ} \mathrm{W} ; 340$ m a.s.l.; 17.X.1968; M. Lamotte leg.; MNHN-RA-1996.638, 1996.643 • 7 ㅇ (SVL 34.4-41.6 mm), 1 o (SVL $28.7 \mathrm{~mm}$ ); Léraba province, between Loumana and Sindou; $10.62052^{\circ} \mathrm{N},-5.29650^{\circ} \mathrm{W} ; 330 \mathrm{~m}$ a.s.l.; 4.XI.1970; M. Lamotte leg.; MNHN-RA-1996.8741, 1996.8742, 1996.8743, 1996.8744, $1996.8745,1996.8746,1996.8747,1996.8748 \cdot 8$ subadults (SVL 23.3-30.5 mm); Léraba province, north-east of Ferké (close to the Ivorian border); 10.XI.1970; M. Lamotte leg.; MNHNRA-1996.8749, 1996.8751, 1996.8738, 1996.8739, 1999.7315, $1999.7316,1999.7318,1999.7320 \bullet 1$ Q (SVL $47.3 \mathrm{~mm}$ ); Comoé province, in Timpérada River near Yendéré; $10.20861^{\circ} \mathrm{N},-4.97900^{\circ} \mathrm{W}$; 300 m a.s.l.; 28.X.1970; M. Lamotte leg.; MNHN-RA-1996.8737.

FIELD MATERIAL. - Burkina Faso • 5 juveniles (SVL 16.1-19.8 mm); Koubri Nabazana dam; $12.20319^{\circ} \mathrm{N},-1.35105^{\circ} \mathrm{W} ; 280 \mathrm{~m}$ a.s.l.; 17.VII.2017; H. J. Ayoro \& A. Ohler leg.; under accumulated dry grasses; hand capture $\bullet 1$ juvenile (SVL $24.3 \mathrm{~mm}$ ); Deux Balés National Park, Ouahabou bouli; $11.60767^{\circ} \mathrm{N},-3.06035^{\circ} \mathrm{W} ; 260 \mathrm{~m}$ a.s.l.; 8.XI.2017; H. J. Ayoro leg.; under dead wood near water body; hand capture 1 ㅇ (SVL $31.5 \mathrm{~mm}$ ); downstream from Soumbou dam; $11.69872^{\circ} \mathrm{N},-2.79738^{\circ} \mathrm{W} ; 260 \mathrm{~m}$ a.s.l.; 8.XI.2017; same collector as for preceding; under a stone near water body; hand capture $\bullet 3$ ? (SVL33.0-35.5 mm), 10 subadults (SVL 28.2-30.5 mm); "Baignade des Eléphants"; $11.71816^{\circ} \mathrm{N},-2.83777^{\circ} \mathrm{W} ; 260$ m a.s.1.; 8.XI.2017; same collector as for preceding; on dry grasses near water body; hand capture $\bullet 1$ juvenile (SVL $23.1 \mathrm{~mm}$ ); Kohéna pond; $11.67601^{\circ} \mathrm{N}$, $-2.83577^{\circ} \mathrm{W} ; 265 \mathrm{~m}$ a.s.l.; 9.XI.2017; same collector as for preceding; around water body; hand capture $\bullet 3$ ㅇ (SVL 37.4-38.6 mm); Tiona pond; $11.63241^{\circ} \mathrm{N},-2.85437^{\circ} \mathrm{W} ; 265 \mathrm{~m}$ a.s.l.; 9.XI.2017; same collector as for preceding; under dry grasses around water body; hand capture 5 subadults (SVL 26.7-31.5 mm); the bank of Mouhoun River; $11.77890^{\circ} \mathrm{N},-2.91259^{\circ} \mathrm{W} ; 245 \mathrm{~m}$ a.s.l.; $10 . X I .2017$; same collector as for preceding; on mud and under grasses; hand capture - 3 ㅇ (SVL 33.1-37.0 mm), 2 subadults (SVL 30.0-30.5 mm); W National Park, the edge of Gnifagou pond; $12.02083^{\circ} \mathrm{N}, 2.20222^{\circ} \mathrm{E}$; $280 \mathrm{~m}$ a.s.l.; 3.II.2017; same collector as for preceding; under the dead wood near water body; hand capture $\bullet 3$ \% (SVL 31.7-38.8 mm), 1 subadult (SVL $29.1 \mathrm{~mm}$ ); W National Park, the edge of Soanda pond; $12.02861^{\circ} \mathrm{N}, 2.25890^{\circ} \mathrm{E} ; 260 \mathrm{~m}$ a.s.l.; 3.II.2017; same collector as for preceding; under stones near water body; hand capture - 1 9 (SVL $31.8 \mathrm{~mm}$ ); Mékrou River (close to the Beninese border); $11.89991^{\circ} \mathrm{N}, 2.40260^{\circ} \mathrm{E} ; 240 \mathrm{~m}$ a.s.l.; 4.II.2017; same collector as for preceding; under rocks on the bank of the river; hand capture - $1 \mathrm{O}^{\text {"7 }}$ (SVL $38.7 \mathrm{~mm}$ ); Kabougou River; $11.96860^{\circ} \mathrm{N}, 2.01259^{\circ} \mathrm{E}$; $280 \mathrm{~m}$ a.s.l.; 18.VI.2018; same collector as for preceding; in paddy field; hand capture 1 \%; on the edge of PK-27 bouli; $11.88744^{\circ} \mathrm{N}$, $2.11913^{\circ} \mathrm{E} ; 265 \mathrm{~m}$ a.s.l.; 20.VI.2018; same collector as for preceding; around water body; hand capture $\bullet 1$ juvenile (SVL $18.5 \mathrm{~mm}$ ); W National Park, Nangouli swampy valley; $11.89793^{\circ} \mathrm{N}, 2.00091^{\circ} \mathrm{E}$; $250 \mathrm{~m}$ a.s.l.; 21.VI.2018; same collector as for preceding; on a stone near water body; hand capture 1 \% (SVL $40.3 \mathrm{~mm}$ ), 2 subadults (SVL 26.1-29.3 mm); the bank of Arly River; $11.57048^{\circ} \mathrm{N}$, $1.45218^{\circ} \mathrm{E} ; 160 \mathrm{~m}$ a.s.l.; 3.III.2017; same collector as for preceding; in a crack of dry mud; hand capture $110^{7}$ (SVL $32.3 \mathrm{~mm}$ ), 1 \% (SVL $32.0 \mathrm{~mm}$ ); Bongola swampy valley; $11.53252^{\circ} \mathrm{N}, 1.48241^{\circ} \mathrm{E}$; $170 \mathrm{~m}$ a.s.l.; 13.VI.2018; same collector as for preceding; near water body; hand capture $3 \mathrm{O}^{\prime \prime}$ (SVL 33.1-36.0 mm); Arly National Park, on the floodplain; $11.57852^{\circ} \mathrm{N}, 1.46004^{\circ} \mathrm{E} ; 255 \mathrm{~m}$ a.s.l; $16-17$. VI.2018; same collector as for preceding; around water body; hand capture 3 9 (SVL 44.8-49.5 mm); Comoé-Léraba Forest, Baboro swampy valley; $9.92521^{\circ} \mathrm{N},-4.57391^{\circ} \mathrm{W} ; 230 \mathrm{~m}$ a.s.l.; 4.VIII.2018; H. J. Ayoro \& A. Ohler leg.; under a heap of dead branches and leaves in a fallow field; hand capture 1 O (SVL $32.5 \mathrm{~mm}$ ); Tuy province, at the backwater of Fafo; $11.33470^{\circ} \mathrm{N},-3.01947^{\circ} \mathrm{W}$; $300 \mathrm{~m}$ a.s.l.; 4.XI.2018; H. J. Ayoro leg.; in a vegetable garden; hand cpature - Ioba province, Dano; $11.16600^{\circ} \mathrm{N},-3.08688^{\circ} \mathrm{W}$; $340 \mathrm{~m}$ a.s.l.; J. Penner leg. • Gbagba (close to Dano); $11.18133^{\circ} \mathrm{N}$, $-3.05164^{\circ} \mathrm{W} ; 300 \mathrm{~m}$ a.s.l.; 2011 ; J. Penner leg.; field observation.

LiTERATURE REPORTS. - Burkina Faso • Passoré province, $80 \mathrm{~km}$ north-west Ouagadougou; $12.96744^{\circ} \mathrm{N},-2.26155^{\circ} \mathrm{W} ; 330 \mathrm{~m}$ a.s.l.; 30.VII.1992 (Böhme et al. 1996) - Yatenga province, Roba near Zamioro; $13.66675^{\circ} \mathrm{N},-2.50001^{\circ} \mathrm{W} ; 350 \mathrm{~m}$ a.s.l. (Lamotte \& Ohler 1997) - Gourma province, Fada N'gourma; $12.06051^{\circ} \mathrm{N}$, $0.34913^{\circ} \mathrm{E} ; 300 \mathrm{~m}$ a.s.l. (Mohneke 2011; Mohneke et al. 2011) - Ganzourgou province, Mogtedo; $12.31844^{\circ} \mathrm{N},-0.83601^{\circ} \mathrm{W}$; $280 \mathrm{~m}$ a.s.l. (Mohneke 2011; Mohneke et al. 2011) • Zorgho; $12.2483^{\circ} \mathrm{N},-0.6278^{\circ} \mathrm{W} ; 300 \mathrm{~m}$ a.s.l.; I-III.2008 (Mohneke 2011; Mohneke et al. 2011).

DESCRIPTION. - 76 specimens examined. Newly collected females 31.7-49.5 mm SVL, males 33.2-38.7 mm SVL. Smaller than Lamotte \& Ohler (1997) vouchers: males 38-51 mm and females 40$61 \mathrm{~mm}$. Specimens with a pointed snout, distinct and long limbs. Webbing formula: I 1 - 2 II 1 - 2 1 1/2 III 1 - 3 IV $2 \frac{1}{2}-1$ V. Presence of supernumerary tubercles on the toes III and IV. Three pairs of dorsal ridges, including a pair of sacral ridges, a pair of ridges visible on the head between the eyes and ending in the lower part of the back, a second pair of ridges from behind the eyes to the same level as the median ridges and a third pair of ridges visible approximately above the tympanum, near the eye to the level of the other two pairs. The second and third pairs of ridges discontinuous in some 

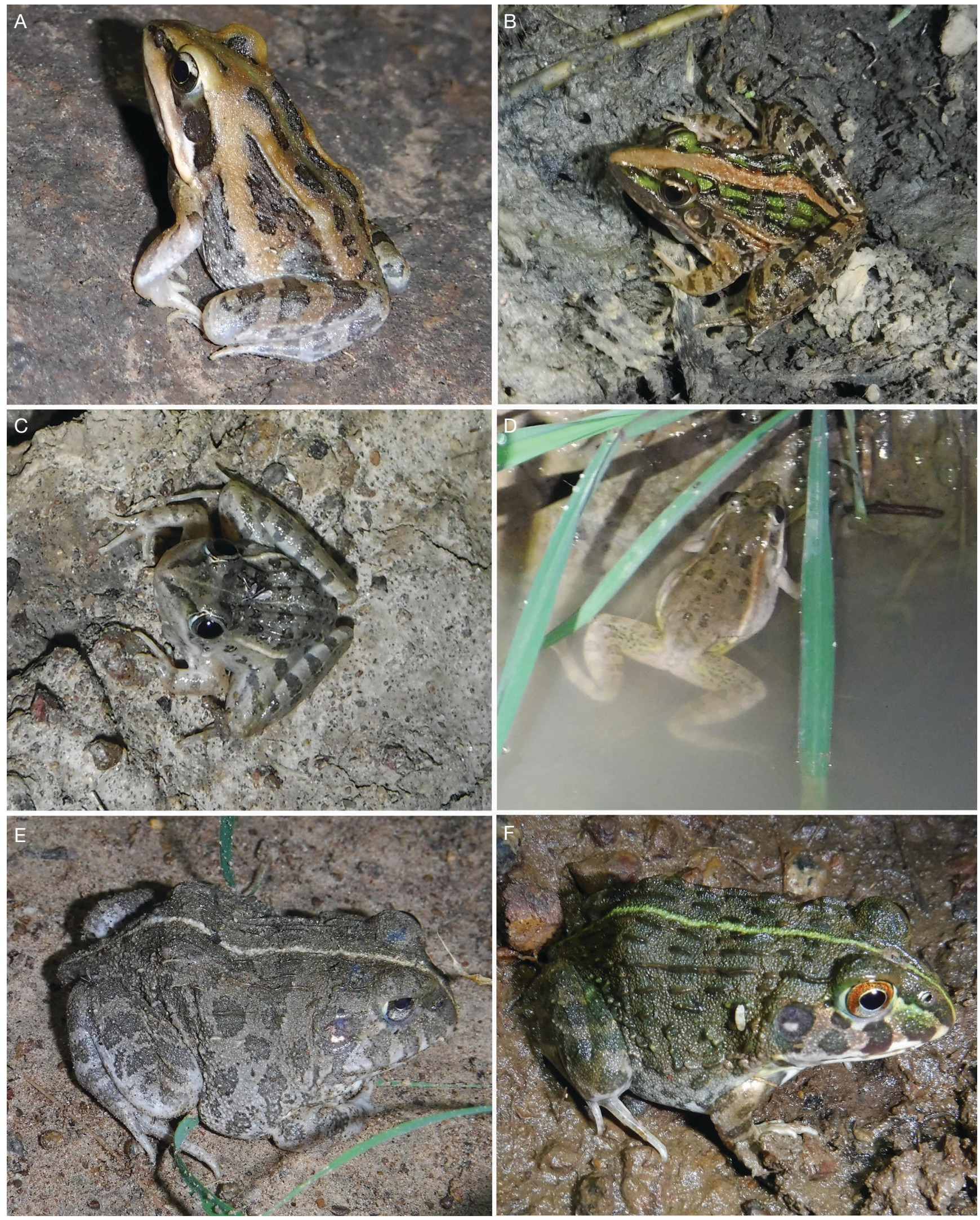

Fig. 6. - Representatives of anuran species from Burkina Faso in life. A, Hildebrandtia ornata (Peters, 1878); B-C, Ptychadena pumilio (Boulenger, 1920); D, Ptychadena schillukorum (Werner, 1908); E-F, Pyxicephalus maltzanii (Boulenger, 1882). Photos: Halamoussa Joëlle Ayoro. 
specimens. A lateral ridge usually absent or only present as a short row of discontinuous light warts. For further detailed descriptions see Lamotte \& Ohler (1997) and Rödel (2000).

Dorsum a grey to pale brown with numerous tiny dark brown to black spots, restricted to the longitudinal ridges. Light reddish or yellow vertebral lines may be present or absent.

HABITAT. - We encountered this species under grasses at the edges of ponds and on river banks. It was also found in paddy fields. In the dry season, we collected $P$. bibroni under rocks, deadwood and accumulated dry grass around ponds. The species was found in dry and wet savannah habitats, intermittent freshwater wetlands, rura gardens, heavily degraded forests (agricultural areas), channels and ditches (Rödel 2000). It is a common species, widely distributed in West Africa (Lamotte \& Ohler 1997; Nago et al. 2006; Segniagbeto et al. 2007; Mohneke et al. 2011; Onadeko 2016; SánchezVialas et al. 2017).

\section{Ptychadena mascareniensis (Guibé \& Lamotte, 1953)} (Fig. 7C)

Collection MATERIAl. - Burkina Faso • 1 \% (SVL 38.6 mm); Passoré province, Samba; $2.70144^{\circ} \mathrm{N},-2.40389^{\circ} \mathrm{W} ; 290 \mathrm{~m}$ a.s.l.; I.1963; M. Lamotte leg.; MNHN-RA-1979.5118 • 3 subadults (SVL 27.1-30.2 mm); Nasso; close to the Kou River; $11.20955^{\circ} \mathrm{N}$, $-4.43951^{\circ} \mathrm{W} ; 340 \mathrm{~m}$ a.s.1.; 28.XI.1968; M. Lamotte leg.; MNHNRA-1996.3897, 1996.3898, 1996.3899・ 1 subadult (SVL $26.7 \mathrm{~mm}$ ); Léraba province, Loumana; 3.XI.1970; J. J. Morère leg.; MNHNRA-1996.3947 • 2 subadults (SVL 27.1-28.8 mm); Léraba province, north-east Ferké (close to the Ivorian border); 10.XI.1970 M. Lamotte leg.; MNHN-RA-1999.7317, 1999.7319• 1 subadult (SVL $26.5 \mathrm{~mm}$ ); Houet province, on a trail linking Bobo-Dioulasso and Kofila; 1970; M. Lamotte leg.; MNHN-RA-1996.3937 - 1 9 (SVL $39.1 \mathrm{~mm}$ ); Houet province, Dindérésso; $11.23055^{\circ} \mathrm{N}$, $-4.37329^{\circ} \mathrm{W} ; 340$ m a.s.l.; 31.X.1970; M. Lamotte leg.; MNHNRA-1996.3916.

FIELD MATERIAL. - Burkina Faso • 1 9 (SVL 37.7 mm); Deux Balés National Park, "Baignade des Eléphants"; $11.71816^{\circ} \mathrm{N},-2.83777^{\circ} \mathrm{W}$; 260 m a.s.l.; 8.XI.2017; H. J. Ayoro leg.; on dry grasses around water body; hand capture 1 subadult (SVL $32.1 \mathrm{~mm}$ ); Arly National Park; close to Bouliabou pond; $11.5789^{\circ} \mathrm{N}, 1.46397^{\circ} \mathrm{W} ; 180 \mathrm{~m}$ a.s.l.; 11.VI.2018; same collector as for preceding; on the edge of the pond; hand capture $10^{\text {7 }}$ (SVL $34.4 \mathrm{~mm}$ ); Comoé-Léraba Forest; Baboro swampy valley; $9.92521^{\circ} \mathrm{N},-4.57391^{\circ} \mathrm{W} ; 230 \mathrm{~m}$ a.s.l.; 4.VIII.2018; H. J. Ayoro \& A. Ohler leg.; under grasses on a way; hand capture.

Literature REPORTS. - Burkina Faso • Gourma province, Fada $\mathrm{N}^{\prime}$ gourma; $12.06051^{\circ} \mathrm{N}, 0.34913^{\circ} \mathrm{E} ; 300 \mathrm{~m}$ a.s.l. $\bullet$ Ganzourgou province, Mogtedo; $12.31844^{\circ} \mathrm{N},-0.83601^{\circ} \mathrm{W} ; 280 \mathrm{~m}$ a.s.l. (Mohneke 2011; Mohneke et al. 2011) •Zorgho; $12.2483^{\circ} \mathrm{N},-0.6278^{\circ} \mathrm{W}$; 300 m a.s.l.; I-III.2008 (Mohneke 2011; Mohneke et al. 2011).

DESCRIPTION. - 12 specimens examined. SVL of $34.4 \mathrm{~mm}$ for the single male and 38.6-39.1 $\mathrm{mm}$ for females and thus smaller than size given by Rödel (2000). Specimens with a pointed snout, long legs and webbing formula: I 1 - 2 II 1 - 2 III 1 - 2 IV 2 - 1 V. Supernumerary tubercles absent. On the back four pairs of continuous longitudinal folds. The median pair from between eyes to the sacrum. The second pair starting posterior to eye and ranging to lower part of the back. The third pair, shorter and between the second pair and continuous white lateral folds posterior to the eyelid to the groin. A light medio-dorsal line, from the snout to the venter and also a fine white line on the dorsal part of the leg present (Fig. 7C). Generally presence of a broad green or redish vertebral band in this species (see figures in Rödel \& Glos 2019). Dominant colour brown, dotted with dark and whitish spots on the back and on posterior legs.
COMMENT. - The taxonomy of the P. mascareniensis-complex is not yet settled. According to Rödel (2000) and Vences et al. (2004) this nomen represents a series of cryptic species. A series of distinct clades traditionally named $P$. mascareniensis in Africa and the populations present in Madagascar and Réunion Island (origin of name-bearing specimens) are morphologically and genetically differentiated from those of other African populations (Vences et al. 2004; Zimkus et al. 2017). The recent phylogenetic study on $P$. mascareniensis (Zimkus et al. 2017) confirmed the genetic differentiation, however, without clarifying the taxonomy of West African populations.

Habitat. - Ptychadena mascareniensis was captured on the edge of a small pond in National Parks of Arly and Deux Balés and under grasses in water-filed depression in Comoé-Léraba Forest. The species inhabits savannah habitats in West Africa, breeding most often in paddy fields (Rödel 2000, Segniagbeto et al. 2007). It was found near a temporary pond in a gallery forest of the Sahel savannah (Padial \& De La Riva 2004).

\section{Ptychadena oxyrhynchus (Smith, 1849)}

COLLECTION MATERIAL. — Burkina Faso • 2 9 (SVL 52-57 mm); Léraba province, near Katiaré (north-east Ferké); $9.91200^{\circ} \mathrm{N},-4.94771^{\circ} \mathrm{W}$; 250 m a.s.l.; 10.XI.1970; M. Lamotte leg.; MNHN-RA-1996.3873, $1996.3874 \cdot 2$ 우 (SVL 48.5-64.2 mm), 1 o $^{7}$ (SVL 55.2 mm); BoboDioulasso; $11.18801^{\circ} \mathrm{N},-4.29743^{\circ} \mathrm{W} ; 280 \mathrm{~m}$ a.s.l.; 6.XI.1970; M. Lamotte leg.; MNHN-RA-1996.3869, 1996.3870, 1996.3871.

FIELD MATERIAL. - Burkina Faso • $1 \mathrm{O}^{7}$ (SVL $\left.47.8 \mathrm{~mm}\right), 1$ \% (SVL $62.3 \mathrm{~mm}$ ); Tuy province, Fafo dam; $11.33470^{\circ} \mathrm{N},-3.01947^{\circ} \mathrm{W}$; $300 \mathrm{~m}$ a.s.l.; 8.XI.2018; H. J. Ayoro leg.; in a vegetable garden; hand capture.

LITERATURE REPORTS. - Burkina Faso • Gourma province, Fada $\mathrm{N}^{\prime}$ gourma; $12.06051^{\circ} \mathrm{N}, 0.34913^{\circ} \mathrm{E}$; $300 \mathrm{~m}$ a.s.l.; (Mohneke 2011; Mohneke et al. 2011) • Ganzourgou province, Mogtedo; $12.31844^{\circ} \mathrm{N}$, $-0.83601^{\circ} \mathrm{W} ; 280 \mathrm{~m}$ a.s.l. (Mohneke 2011; Mohneke et al. 2011) - Zorgho; $12.2483^{\circ} \mathrm{N},-0.6278^{\circ} \mathrm{W} ; 300 \mathrm{~m}$ a.s.l.; I-III.2008 (Mohneke 2011; Mohneke et al. 2011).

DESCRIPTION. - 7 specimens studied. Five females 48.5-64.2 mm; SVL of two males 47.8-55.2 mm SVL, close to e.g. those given by Konan et al. (2016), male size as 46.0-60.9 mm and females size as 58.0-65.1 mm; and by Rödel (2000), males 40-53 mm, females $51-64 \mathrm{~mm}$. Snout very pointed and hind legs very long. Webbing formula: I 0 - 1/2 II 0 - 1 III 0 - 1 IV 1 - 0 V. On the back presence of four pairs of longitudinal ridges; a pair of short ridges and white lateral ridges on the flanks. Dominant dorsal colour a greyish to brown.

HABITAT. - During the dry season, the species can be found under stones on river banks, whereas they breed in savannah ponds during the rainy season (Rödel 2000). This frog occurs in open landscapes, savannah-forest ecotone and the degraded part of rainforest (Hughes 1988; Konan et al. 2016; Onadeko 2016). Some authors also list more arid habitats (Amiet 1974). It is widely distributed in West Africa and in a large part of sub-Saharan Africa from Senegal to South Africa (Rödel 2000; Channing 2001; Channing \& Howell 2006).

Ptychadena pumilio (Boulenger, 1920) (Fig. 6B, C)

COllection Material. - Burkina Faso • 6 ㅇ (SVL 25-27 mm), $10^{\prime \prime}$ (SVL $29.2 \mathrm{~mm}$ ); Nasso; $11.20950^{\circ} \mathrm{N},-4.43952^{\circ} \mathrm{W} ; 340 \mathrm{~m}$ a.s.l.; 6.XII.1968; M. Lamotte leg.; MNHN-RA-1999.7572, 1999.7573, 1999.7574, 1996.3900, 1996.3901, 1996.3902, 1996.3923 - 6 9 (SVL 25.3-34.0 mm); Bobo-Dioulasso, Pala; $11.14985^{\circ} \mathrm{N}$, 
A
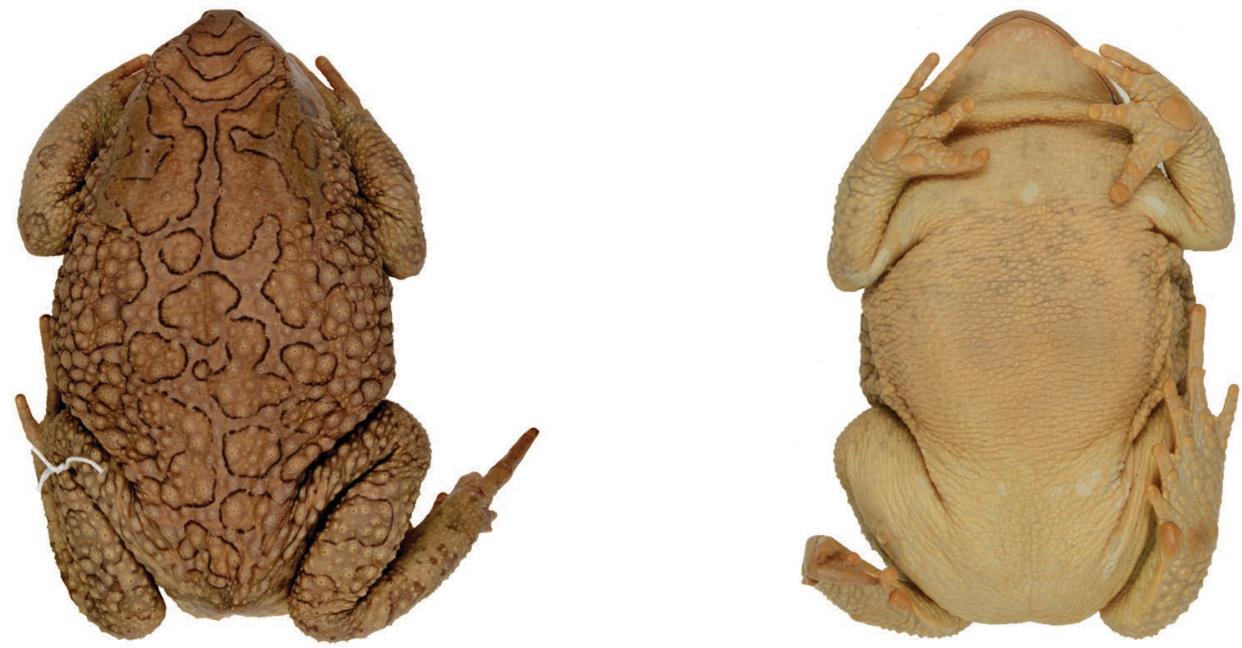

B
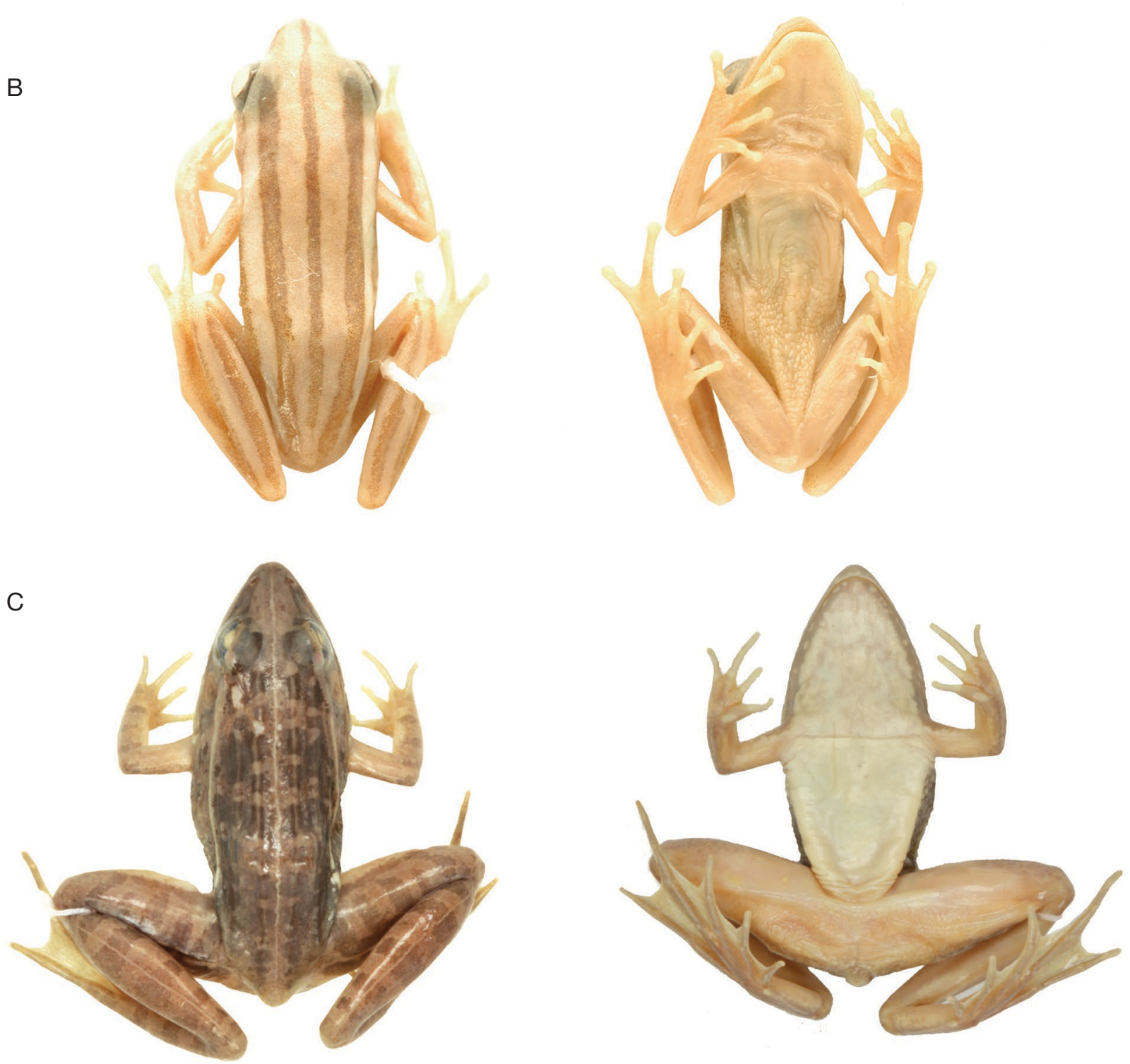

FIG. 7. - Photos of collection vouchers: three anuran species from Burkina Faso preserved in alcohol, dorsal view (left) and ventral view (right). A, Sclerophrys mauritanica (Schlegel, 1841); MNHN-RA-1989.4038; B, Hyperolius lamottei Laurent, 1958; MNHN-RA-1997.9889; C, Ptychadena mascareniensis (Guibé \& Lamotte, 1953); MNHN-RA-1996.3916. Photos: A, C, Halamoussa Joëlle Ayoro; B, Annemarie Ohler. 
$-4.22671^{\circ} \mathrm{W} ; 430 \mathrm{~m}$ a.s.l.; XI.1970; M. Lamotte leg.; MNHNRA-1996.3921, 1996.3922, 1996.3924, 1996.3925, 1996.3926 , $1996.3927 \cdot 3$ ㅇ (SVL 25-27.4 mm); Loumana; $10.58001^{\circ} \mathrm{N}$, $-5.35043^{\circ} \mathrm{W} ; 330 \mathrm{~m}$ a.s.l.; 30.X.1970; M. Lamotte leg.; MNHNRA-1996.7506, 1996.7507, 1996.7508 • 6 ơ (SVL 27.1-29.5 mm), 7 ㅇ (SVL 27.2-34.7 mm), 8 subadults (SVL 18.8-24.1 mm); Samba; $12.70144^{\circ} \mathrm{N},-2.40390^{\circ} \mathrm{W} ; 290 \mathrm{~m}$ a.s.l.; VII.1962; M. Lamotte leg.; MNHN-RA-1996.3885, 1996.3888, 1996.3889, 1996.3894 , 1996.3895, 1996.3896, 1996.3886, 1996.3887, 1996.3890, $1996.3892,1996.3893,1996.3878,1996.3806,1996.3876$, 1996.3877, 1996.3879, 1996.3880, 1996.3881, 1996.3882, 1996.3883, 1996.3884 • 1 subadult (SVL $25.2 \mathrm{~mm}$ ); Dano, Batiara; $11.21325^{\circ} \mathrm{N},-3.02682^{\circ} \mathrm{W} ; 280 \mathrm{~m}$ a.s.l.; 21.X.2003; M.-O. Rödel leg.; ZMB 84696.

FIELD MATERIAL. - Burkina Faso • 1 subadult (SVL $23.8 \mathrm{~mm}$ ); W National Park; Kabougou River (its protected part); $11.97060^{\circ} \mathrm{N}$, $2.01627^{\circ} \mathrm{E} ; 265 \mathrm{~m}$ a.s.l.; 4.II.2017; H. J. Ayoro leg.; hidden under a dead wood; hand capture $\bullet 4$ subadults (SVL 18.0-24.6 mm); Arly National Park, the edge of Bouliabou pond; $11.57892^{\circ} \mathrm{N}$, $1.46397^{\circ} \mathrm{E} ; 180 \mathrm{~m}$ a.s.l.; 2.III.2017; same collector as for preceding; in the cracks of dry mud; hand capture $20^{7}$ (SVL 26.7-29.6 mm); the edge of Bouliabou pond; $11.57892^{\circ} \mathrm{N}, 1.46397^{\circ} \mathrm{E} ; 180 \mathrm{~m}$ a.s.l.; 11.VI.2018; same collector as for preceding; hand capture $\bullet 20^{3}$ (SVL 26.4-27.4 mm); Arly National Park, the floodplain $(500 \mathrm{~m}$ north of Bouliabou pond); $11.57852^{\circ} \mathrm{N}, 1.46004^{\circ} \mathrm{E} ; 255 \mathrm{~m}$ a.s.l.; 16-17.VI.2018; same collector as for preceding; near water body; hand capture 5 subadults (SVL 21.5-25.5 mm); Deux Balés National Park, the edge of "Baignade des Eléphants"; $11.71809^{\circ} \mathrm{N}$, $-2.83793^{\circ} \mathrm{W} ; 270 \mathrm{~m}$ a.s.l.; 8.XI.2017; same collector as for preceding; on dry grasses; hand capture $\bullet 5$ individuals; Deux Balés National Park, the edge of Jonction pond; $11.56736^{\circ} \mathrm{N},-2.86041^{\circ} \mathrm{W} ; 255 \mathrm{~m}$ a.s.l.; 9.XI.2017; same collector as for preceding; on the mud; visual report • 9 ㅇ (SVL 28.5-30.9 mm), 3 subadults (SVL 25.0-26.5 mm); the edge of Kohéna pond; $11.67662^{\circ} \mathrm{N},-2.83611^{\circ} \mathrm{W} ; 270 \mathrm{~m}$ a.s.l.; 9.XI.2017; same collector as for preceding; under dead wood and on the mud; hand capture 19 (SVL $29.0 \mathrm{~mm}$ ); the edge of Tiona pond; $11.63241^{\circ} \mathrm{N},-2.85437^{\circ} \mathrm{W} ; 265 \mathrm{~m}$ a.s.l.; 9.XI.2017; same collector as for preceding; under dry grasses; hand capture $\bullet 2$ subadults (SVL 25.6-27.0 mm); Deux Balés National Park, a flooded zone of Mouhoun River; $11.77879^{\circ} \mathrm{N},-2.91244^{\circ} \mathrm{W} ; 245 \mathrm{~m}$ a.s.l.; 10.XI.2017; same collector as for preceding; on dry gasses; hand capture $\bullet 1 \%$ (SVL $37.1 \mathrm{~mm}$ ); Baboro swampy valley; $9.92521^{\circ} \mathrm{N},-4.5739^{\circ} \mathrm{W}$ 230 m a.s.l.; 4.VIII.2018; H. J. Ayoro \& A. Ohler leg.; near small water body; hand capture 11 (SVL $36.3 \mathrm{~mm}$ ); flooded zone of the Comoé River; $9.93239^{\circ} \mathrm{N},-4.60655^{\circ} \mathrm{W} ; 220 \mathrm{~m}$ a.s.l.; 5.VIII.2018; same collectors as for preceding; near water body; hand capture $20^{\prime}$; Kou Forest, in its savannah part; $11.18815^{\circ} \mathrm{N},-4.44397^{\circ} \mathrm{W} ; 375 \mathrm{~m}$ a.s.l.; 9.VIII.2018; same collectors as for preceding; under flooded grasses on a trail; acoustic report $\bullet 3 \mathrm{O}^{\top}$; Dori, Toroodi; $14.00554^{\circ} \mathrm{N},-0.02405^{\circ} \mathrm{W}$; 280 m a.s.l.; 24.VIII.2018; H. J. Ayoro leg.; visual and acoustic reports - 1 ( (SVL $34.2 \mathrm{~mm}$ ), $30^{\text {" }}$ (SVL 28.2-30.2 mm); the edge of Dori pond, swampy valley (on the road out from Dori to Gorom-Gorom); $14.04736^{\circ} \mathrm{N},-0.05723^{\circ} \mathrm{W} ; 270$ m a.s.l.; 25 .VIII. 2018; same collector as for preceding; under small submerged grasses; hand capture and acoustic report $10^{7}$ (SVL $\left.33.0 \mathrm{~mm}\right), 19$ (SVL $\left.32.7 \mathrm{~mm}\right)$; the edge of Pabré dam; $12.51597^{\circ} \mathrm{N},-1.59923^{\circ} \mathrm{W} ; 290 \mathrm{~m}$ a.s.l.; $10-12$. VII.2017; H. J. Ayoro \& A. Ohler leg.; around small water body; hand capture 1 \% (SVL $33.7 \mathrm{~mm}$ ); the edge of "Ancien barrage"; $12.22843^{\circ} \mathrm{N},-1.34766^{\circ} \mathrm{W} ; 280 \mathrm{~m}$ a.s.l.; $16 . V I I .2017$; same collector as for preceding; in the paddy field; hand capture 4 subadults (SVL 22.9-28.7 mm); the edge of Fafo dam; $11.33470^{\circ} \mathrm{N},-3.01947^{\circ} \mathrm{W}$; $300 \mathrm{~m}$ a.s.l.; 10.XI.2018; H. J. Ayoro leg.; in a vegetable garden; hand capture $\bullet$ Djikologo, close to the Bontioli Reserve; $10.93686^{\circ} \mathrm{N}$ $-3.13800^{\circ} \mathrm{W} ; 260 \mathrm{~m}$ a.s.l.; 2011 ; J. Penner leg.; field direct observation.

Literature RePORTS. - Burkina Faso - Gourma province, Fada N'gourma; $12.06051^{\circ} \mathrm{N}, 0.34913^{\circ} \mathrm{E} ; 300 \mathrm{~m}$ a.s.l. $\bullet$ Ganzourgou province, Mogtedo; $12.31844^{\circ} \mathrm{N},-0.83601^{\circ} \mathrm{W} ; 280 \mathrm{~m}$ a.s.l. $\bullet$ Zorgho; $12.2483^{\circ} \mathrm{N},-0.6278^{\circ} \mathrm{W} ; 300 \mathrm{~m}$ a.s.l.; I-III.2008 (Mohneke 2011; Mohneke et al. 2011).

DESCRIPTION. - 76 specimens studied. Specimens studied 27.2-34.4 $\mathrm{mm}$ SVL in males and 29.0-37.1 mm SVL in females; thus within the size range given by Rödel (2000) and Lamotte (1967a). Species with a moderately pointed snout and a slender body. Limbs thin and long; webbing formula: I 1 - 2 II 1 - 2 III $1 \frac{1}{2}-2$ IV $2-1 \mathrm{~V}$. Supernumerary tubercles absent on toes. Three pairs of symmetrical and continuous ridges present on the back. A white, continuous lateral ridge extending from above the tympanum to the posterior part of the back. Dorsal colour pattern from brown, greenish to greyish with dark brown spots (Fig. 6B, C). Breeding males with greenish colour (Rödel 2000). Presence of a wide white, green or red vertebral band in many specimens.

Habitat. - Ptychadena pumilio is ubiquitous in Guinean and Sudanese savannah and Sahelian habitats. It may even enter degraded rainforest (Rödel 2000). We found it near water bodies among grasses and sometimes in the humid areas near water bodies in depressions, as well as in flooded zones in the rainy season. In Dori, we found calling males between flooded short grasses. In the dry season, $P$. pumilio was observed concealing under rocks, heaps of dry grass and cracks of dry mud around ponds and river banks, in Arly and W National Park from February to March 2017 and in Deux Balés National Park in November 2017.

\section{Ptychadena schillukorum (Werner, 1908)} (Figs 6D, 8A)

Field MATERIAL. - Burkina Faso • $2 \mathrm{O}^{\mathrm{7}}$ (SVL 33.3-35.9 mm); Arly National Park, the floodplain; $11.57852^{\circ} \mathrm{N}, 1.46004^{\circ} \mathrm{W}$; $255 \mathrm{~m}$ a.s.l.; 16.VI.2018; H. J. Ayoro leg.; around a small water body; hand capture.

Literature Reports. - Burkina Faso - Gourma province, Fada N'gourma; $12.06051^{\circ} \mathrm{N}, 0.34913^{\circ} \mathrm{E} ; 300 \mathrm{~m}$ a.s.l. (Mohneke 2011; Mohneke et al. 2011) • Ganzourgou province, Mogtedo; $12.31844^{\circ} \mathrm{N},-0.83601^{\circ} \mathrm{W} ; 280 \mathrm{~m}$ a.s.l. (Mohneke 2011; Mohneke et al. 2011) • Zorgho; $12.2483^{\circ} \mathrm{N},-0.6278^{\circ} \mathrm{W} ; 300 \mathrm{~m}$ a.s.l.; I-III.2008 (Mohneke 2011; Mohneke et al. 2011).

Description. - 2 specimens studied. Ptychadena with a compact and less slender body than P. pumilio. Limbs comparatively short; webbing formula: I 1 - 11/2 II 0 - 2 III 1 - $2 \frac{1}{2} 2$ IV $2 \frac{1}{1} 2$ - 0 $\mathrm{V}$. Absence of supernumerary tubercles. The back with discontinuous, partly indistinct rows of elongate warts (Fig. 6D; Fig. 8A). A discontinuous white lateral line, extending from above the tympanum to the rear back. Dorsal colour greyish with some darker spots.

COMMENTS. - Specimens identification based on the discontinuous dorsal ridges and their size (see Nago et al. 2006). However, in other parts of Africa, this name is applied to frogs which look completely different (larger and showing continuous dorsal ridges): see e.g. Channing (2001). Werner (1908) indicated in the original description a size ranging from $35-43 \mathrm{~mm}$ for the four females from Sudan.

Habitat. - The two males were captured on the edge of a small water body in the floodplain from Arly National Park. Ptychadena schillukorum inhabits dry savannahs and grasslands (Nago et al. 2006; Sánchez-Vialas et al. 2017) and it breeds in swampy valleys and savannah ponds during the rainy season (Nago et al. 2009). The species, as currently defined, is found across sub-Saharan savannahs of West and East Africa (Stewart 1967; Hughes 1988; Channing 2001; Mohneke et al. 2011; Sow et al. 2017). 

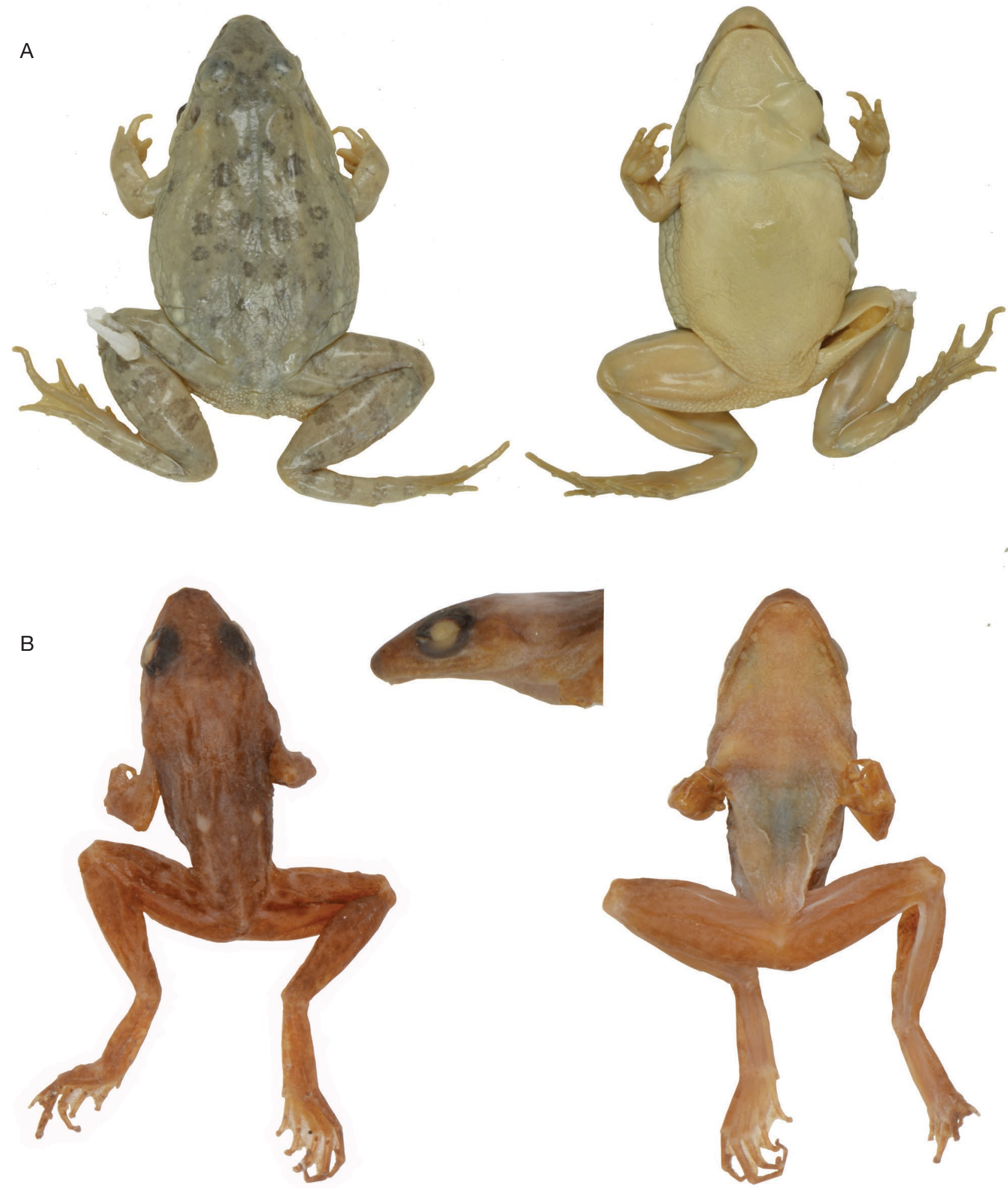

FIG. 8. - Photos of collection vouchers: two anuran species from Burkina Faso preserved in alcohol, dorsal view (left) and ventral view (right) A, Ptychadena schillukorum (Werner, 1908) a field specimen to complete the Fig. 6D; B, Amnirana albolabris (west) Jongsma et al. (2018), MNHN-RA-1999.7575. Photos: A, Halamoussa Joëlle Ayoro; B, Annemarie Ohler. 


\section{Ptychadena tellinii (Peracca, 1904)}

COLleCtion MATERIAL. - Burkina Faso • 2 9 (SVL 34.5-42 mm); Houet province, Sokourani near Hippopotamus pond; $11.51185^{\circ} \mathrm{N}$, $-4.11611^{\circ} \mathrm{W} ; 320 \mathrm{~m}$ a.s.1.; 8.XI.1970; M. Lamotte leg.; MNHNRA-1998.2724, 1998.2725 • 6 9 (SVL 35.3-47.2 mm); BoboDioulasso, Pala; $11.18803^{\circ} \mathrm{N},-4.29744^{\circ} \mathrm{W} ; 430 \mathrm{~m}$ a.s.l.; XI.1970; M. Lamotte leg.; MNHN-RA-1997.1032, 1997.1033, 1997.1034, $1997.1035,1997.1036,1997.1037 \cdot 20^{\pi}$ (SVL 31.5-34.0 mm); Kourweogo province, Laye; $12.53083^{\circ} \mathrm{N},-1.77152^{\circ} \mathrm{W} ; 290 \mathrm{~m}$ a.s.l.; X.1970; M. Lamotte leg.; MNHN-RA-1998.2009, 1998.2010•1우 (SVL $40.1 \mathrm{~mm}$ ), 2 subadults (SVL 23-25.8 mm); Léraba province, Sindou; $10.66981^{\circ} \mathrm{N},-5.16290^{\circ} \mathrm{W} ; 380 \mathrm{~m}$ a.s.l.; 4.XI.1970; M. Lamotte leg.; MNHN-RA-1998.2731, 1998.2732, 1996.3865・1 ㅇ (SVL $37.8 \mathrm{~mm}$ ); Fada N'Gourma; $12.06055^{\circ} \mathrm{N}, 0.34910^{\circ} \mathrm{E} ; 290 \mathrm{~m}$ a.s.l.; II.1983; H. Meyer leg.; ZFMK 38701 • 1 subadult (SVL 25.2 mm); Dano, Batiara; $11.21322^{\circ} \mathrm{N},-3.02685^{\circ} \mathrm{W} ; 280 \mathrm{~m}$ a.s.l.; 21.X.2003; NA leg.; ZMB 84696.

FIELD MATERIAL. - Burkina Faso • 1 \% (SVL $40.6 \mathrm{~mm}$ ); around the "Baignade des Eléphants"; $11.71809^{\circ} \mathrm{N},-2.83793^{\circ} \mathrm{W} ; 270 \mathrm{~m}$ a.s.l.; 8.XI.2017; H. J. Ayoro leg.; under dry grasses; hand capture $\bullet 1$ \% (SVL $34.8 \mathrm{~mm}$ ); Petit Balé dam; $11.59999^{\circ} \mathrm{N},-2.92701^{\circ} \mathrm{W} ; 240 \mathrm{~m}$ a.s.l.; 9.XI.2017; same collector as for preceding; under a rock near water body; hand capture 1 subadult (SVL $26.8 \mathrm{~mm}$ ); the edge of Tiona pond; $11.63241^{\circ} \mathrm{N},-2.85437^{\circ} \mathrm{W} ; 265 \mathrm{~m}$ a.s.l.; 9.XI.2017; same collector as for preceding; under dry grasses near water body; hand capture • 1 ㅇ (SVL $40.3 \mathrm{~mm}$ ), 2 subadults (SVL 27.8-32.0 mm); the Mouhoun River bank; $11.77879^{\circ} \mathrm{N},-2.91244^{\circ} \mathrm{W} ; 245 \mathrm{~m}$ a.s.l.; 10.XI.2017; same collector as for preceding; on a heap of dry grasses; hand capture $110^{7}$ (SVL $37.2 \mathrm{~mm}$ ); Arly National Park; $11.57044^{\circ} \mathrm{N}$, $1.45211^{\circ} \mathrm{E} ; 190 \mathrm{~m}$ a.s.l.; 12.VI.2018; same collector as for preceding; close to a small water body on a trail; hand capture $30^{7}$ (SVL 34.2$34.5 \mathrm{~mm}$ ); the floodplain, close to the Bouliabou pond; $11.57852^{\circ} \mathrm{N}$, $1.46004^{\circ} \mathrm{W} ; 255 \mathrm{~m}$ a.s.l.; $16-17$. VI.2018; same collector as for preceding; near water body; hand capture $\bullet 1 \mathrm{O}^{7}$; Loumbila dam; $12.49837^{\circ} \mathrm{N}$, $-1.40313^{\circ} \mathrm{W} ; 285 \mathrm{~m}$ a.s.l.; 15.VII.2017; H. J. Ayoro \& A. Ohler leg.;

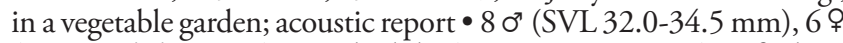
(SVL 36.4-43.7 mm), 11 subadults (SVL 25.8-29.1 mm); Fafo dam; $11.33470^{\circ} \mathrm{N},-3.01947^{\circ} \mathrm{W} ; 300 \mathrm{~m}$ a.s.l.; 10.XI.2018; H. J. Ayoro leg.; in a paddy field; hand capture.

LiTERATURE REPORTS. - Burkina Faso • Gourma province, Fada $\mathrm{N}^{\prime}$ gourma; $12.06051^{\circ} \mathrm{N}, 0.34913^{\circ} \mathrm{E} ; 300 \mathrm{~m}$ a.s.l.; II. 1983 and IIII.2008 (Böhme et al. 1996; Mohneke et al. 2011) • Ganzourgou province, Mogtedo; $12.31844^{\circ} \mathrm{N},-0.83601^{\circ} \mathrm{W} ; 280 \mathrm{~m}$ a.s.l. (Mohneke 2011; Mohneke et al. 2011) • Zorgho; $12.2483^{\circ} \mathrm{N},-0.6278^{\circ} \mathrm{W}$; 300 m a.s.l.; I-III.2008 (Mohneke 2011; Mohneke et al. 2011) • Houet province, Karankasso Vigué; $11.00982^{\circ} \mathrm{N},-3.90001^{\circ} \mathrm{W} ; 300 \mathrm{~m}$ a.s.l.; 1985 (Böhme \& Heath 2018).

DESCRIPTION. - 49 specimens examined. Size measures of our vouchers within the size range of Rödel (2000), 30-39 $\mathrm{mm}$ for males and $36-47 \mathrm{~mm}$ for females. Body of robust shape with a slightly pointed snout and long hind legs. Webbing formula: I $1-1 \frac{1}{2}$ II 0 - 2 III $0-2$ IV $1 \frac{1}{2}-0$ V. No supernumerary tubercles on toes. Numerous, very indistinct, flat and continuous dorsal ridges. Dorsal colour almost uniformly red brown to red. Females more reddish than males. Presence of brown to black lateral bands on flanks. Dark patches of variable size usually present on snout. Color of canthal and tympanic region dark brown to deep black.

COMmENT. - Rana schubotzi Sternfeld, 1917 and Rana huguettae Inger, 1968 are currently considered subjective junior synonyms of Phrynobatrachus tellinii Perraca, 1904, thus the valid name is Ptychadena tellinii (Perret 1981; Largen 2001).

HABITAT. - Specimens collected in Arly National Park were found near a small water body where they were in amplexus. In National
Park of Deux Balés P. tellinii was captured under a rock and an accumulation of dry grasses on the edge of a pond. We heard a male calling in a vegetable garden at Loumbila. Ptychadena tellinii can be found under rocks near rivers and in dry savannah pools in the dry season where it seeks refuge in crevices and between rotten wood (Rödel 2000; Largen 2001).

\section{Ptychadena tournieri (Guibé \& Lamotte, 1955)}

REMARK. - We have not yet found this species, neither during field work nor in the collections. So the following notes are based on literature only (Mohneke 2011).

Literature REPORTS. - Burkina Faso - Ganzourgou province, Kougri; $12.39422^{\circ} \mathrm{N},-1.06500^{\circ} \mathrm{W} ; 270 \mathrm{~m}$ a.s.l. and $12.40554^{\circ} \mathrm{N}$, $-1.04391^{\circ} \mathrm{W} ; 270 \mathrm{~m}$ a.s.l. (Mohneke 2011) • Wayen Rapadama Peulh; $12.36783^{\circ} \mathrm{N},-1.02033^{\circ} \mathrm{W} ; 290 \mathrm{~m}$ a.s.l. (Mohneke 2011) - Gourma province, Pokiamanga; $12.08286^{\circ} \mathrm{N}, 0.44111^{\circ} \mathrm{E} ; 290 \mathrm{~m}$ a.s.l. (Mohneke 2011) $\bullet$ Kompienga province, Kompienga; $11.65222^{\circ} \mathrm{N}$, $0.52365^{\circ} \mathrm{E} ; 260 \mathrm{~m}$ a.s.l.; I-III.2008 (Mohneke 2011).

DESCRIPTION. - Small and extremely slender species, with 33$35 \mathrm{~mm}$ SVL for males and 41-43 mm for females (Rödel 2000). Limbs relatively thick and long as in $P$. pumilio. Webbing formula: I 1 - $1 \frac{1 / 2}{2}$ II 1 - 2 III 1 - 2 IV $1 \frac{1 / 2}{2}-1 \frac{1}{2}$ V. Supernumerary tubercles present but poorly visible on the underside of toes II, III and IV. Three pairs of continuous longitudinal ridges on the back and a continuous white lateral ridge. For detailed descriptions see Rödel (2000) and Lamotte \& Ohler (2000).

Habitat. - Ptychadena tournieri inhabits open savannahs (Schiøtz 1967) and breeds in temporary ponds (Perret 1991; Rödel 2000; Nago et al. 2006). It is common in West African savannahs and has been recorded from southern Senegal to northern Benin (Bourgat 1979; Lamotte 1967a; Rödel 2000; Nago et al. 2006; Segniagbeto et al. 2007).

\section{Ptychadena trinodis (Boettger, 1881)}

COLLECTION MATERIAL. - Burkina Faso • 4 9 (SVL 52.5-55.2 mm); Ouagadougou; $12.38011^{\circ} \mathrm{N},-1.51100^{\circ} \mathrm{W} ; 300 \mathrm{~m}$ a.s.l.; VIII.1966; Père Terrible leg.; MNHN-RA-1995.3233, 1995.3234, 1995.3235, 1995.3236 • 5 우 (SVL 48.1-56.9 mm), 1 ơ (SVL $51.8 \mathrm{~mm}$ ); Loumana; $10.58001^{\circ} \mathrm{N},-5.35044^{\circ} \mathrm{W} ; 330 \mathrm{~m}$ a.s.l.; 3.IX.1970; J. J. Morère leg.; MNHN-RA-1996.3931, 1996.3942, 1996.3943, 1996.3944, 1996.3945, 1996.3946 • 2 ㅇ (SVL 54.1-57.2 mm), $10^{7}$ (SVL $55.7 \mathrm{~mm}$ ); a trail between Bobo-Dioulasso and Kofila; $11.33755^{\circ} \mathrm{N},-3.92852^{\circ} \mathrm{W} ; 290 \mathrm{~m}$ a.s.l.; 7.XI.1970; J. J. Morère leg.; MNHN-RA-1996.3939, 1996.3940, 1996.3941 • 2 subadults (SVL 30.2-34.7 mm); Samba; $12.70144^{\circ} \mathrm{N},-2.40391^{\circ} \mathrm{W} ; 290 \mathrm{~m}$ a.s.l.; 2.I.1963; M. Lamotte leg.; MNHN-RA-1993.3572, 1993.5679.

FIELD MATERIAL. — Burkina Faso • 1 \% (SVL 55.5 mm); Deux Balés National Park, downstream from the Soumbou dam; $11.69872^{\circ} \mathrm{N}$, $-2.79738^{\circ} \mathrm{W} ; 260 \mathrm{~m}$ a.s.l.; 8.XI.2017; H. J. Ayoro leg.; under a stone near water body; hand capture $11 \mathrm{O}^{\text {( }}$ (SVL $53.6 \mathrm{~mm}$ ); Arly National Park; $11.57044^{\circ} \mathrm{N}, 1.45211^{\circ} \mathrm{E} ; 190 \mathrm{~m}$ a.s.l.; 12.VI.2018; same collector as for preceding; near a small water body on a trail; hand capture $110^{\pi}$; Koubri, downstream from Nabazana dam; $12.20319^{\circ} \mathrm{N},-1.35105^{\circ} \mathrm{W} ; 280 \mathrm{~m}$ a.s.l.; 17.VII.2017; H. J. Ayoro \& A. Ohler leg.; in a paddy field; acoustic report - 1 (SVL $52.1 \mathrm{~mm}$ ); Comoé-Léraba Forest, Kotokoi swampy valley; $9.82802^{\circ} \mathrm{N},-4.62727^{\circ} \mathrm{W} ; 230 \mathrm{~m}$ a.s.l.; 3.VIII.2018; same collectors as for preceding; near a small water pool; hand capture 1 subadult (SVL $42.4 \mathrm{~mm}$ ); Baboro swampy valley; $9.92521^{\circ} \mathrm{N},-4.5739^{\circ} \mathrm{W} ; 230 \mathrm{~m}$ a.s.l.; 4.VIII.2018; same collectors 
as for preceding; on a trail; hand capture 1 1 $($ SVL $59.1 \mathrm{~mm}$ ), 6 subadults (SVL 35.7-45.2 mm); Folonzo village swampy valley; $9.88803^{\circ} \mathrm{N},-4.61969^{\circ} \mathrm{W} ; 230 \mathrm{~m}$ a.s.1; 6.VIII.2018; same collectors as for preceding; around a vegetable garden; hand capture - 18 subadults (SVL 25.0-44.1 mm); the flooded zone of Yakouta dam; $14.06117^{\circ} \mathrm{N},-0.13181^{\circ} \mathrm{W} ; 270 \mathrm{~m}$ a.s.1.; 26.VIII.2018; H. J. Ayoro leg.; under grasses; hand capture 44 subadults (SVL 19.1-46.4 mm); the edge of Dori pond, Toroodi; $14.00607^{\circ} \mathrm{N}$, $-0.02846^{\circ} \mathrm{W} ; 280 \mathrm{~m}$ a.s.l.; 24-27.VIII.2018; same collector as for preceding; under grasses; hand capture $\bullet 4$ subadults (SVL 31.1$46.3 \mathrm{~mm}$ ); the edge of N'Djomga pond; $14.07225^{\circ} \mathrm{N},-0.04862^{\circ} \mathrm{W}$ $265 \mathrm{~m}$ a.s.l.; 25.VIII.2018; same collector as for preceding; under grasses near water body; hand capture 3 ? (SVL 52.3-57.3 mm); the edge of Fafo dam; $11.33470^{\circ} \mathrm{N},-3.01947^{\circ} \mathrm{W} ; 300 \mathrm{~m}$ a.s.l.; 10.XI.2018; same collector as for preceding; in paddy field; hand capture 1 o (SVL $59.8 \mathrm{~mm}$ ); Djindjerma, close to Koti; $11.38211^{\circ} \mathrm{N},-3.05145^{\circ} \mathrm{W} ; 310 \mathrm{~m}$ a.s.1.; 1.XI.2018; same collector as for preceding; around a drink water well; hand capture.

Literature RePORTS. - Burkina Faso - Gourma province, Fada N'gourma; $12.06051^{\circ} \mathrm{N}, 0.34913^{\circ} \mathrm{E} ; 300 \mathrm{~m}$ a.s.l. (Mohneke 2011; Mohneke et al. 2011) • Ganzourgou province, Mogtedo; $12.31844^{\circ} \mathrm{N},-0.83601^{\circ} \mathrm{W} ; 280 \mathrm{~m}$ a.s.l. (Mohneke 2011; Mohneke et al. 2011) $\bullet$ Zorgho; $12.2483^{\circ} \mathrm{N},-0.6278^{\circ} \mathrm{W} ; 300 \mathrm{~m}$ a.s.l.; I-III.2008 (Mohneke 2011; Mohneke et al. 2011).

DESCRIPTION. - 54 specimens studied. Stout and robust frogs, with a moderately pointed snout, strong and long limbs. An inner and an external metatarsal tubercle present and very protruding as indicated by Rödel (2000) and Sánchez-Vialas et al. (2017). Webbing formula: I 0 - $1 \frac{1}{1 / 2}$ II 0 - 1 III 0 - $1 \frac{1}{1 / 2}$ IV 1 1/2 - 0 V. Four pairs of continuous dorsal ridges extending along the entire back. In life and alcohol, dorsal colouration from brown to dark grey. Presence of a wide white, yellow in life, vertebral line in all specimens. Species usually with a more granular dorsal skin, in comparison to other members of this genus (Rödel 2000).

Habitat. - Specimens were captured in grasses near water bodies in Comoé-Léraba Forest and Deux Balé National Park; on a trail near a water body in Arly National Park; under humid gasses at Dori pond and Yakouta dam banks. Ptychadena trinodis was one of the most abundant Ptychadena species at savannah ponds during the rainy season (Nago et al. 2006). The species is then virtually restricted to small or tiny water bodies which often lack vegetation (Guibé \& Lamotte 1957; Lamotte 1969; Schiøtz 1967; Perret 1981; Rödel 2000). This species is distributed from West Africa east to northern Democratic Republic of Congo (Rödel 2000; Padial \& De La Riva 2004; Sánchez-Vialas et al. 2017; Böhme \& Heath 2018).

Family PyXICEPHALIDAE Bonaparte, 1850

Pyxicephalus maltzanii (Boulenger, 1882) (Fig. 6E, F)

Collection material. - Burkina Faso - 2 adults; Pabré; $12.51000^{\circ} \mathrm{N},-1.57953^{\circ} \mathrm{W} ; 290 \mathrm{~m}$ a.s.l.; 5.V.1970; M. Lamotte leg.; MNHN-RA-1989.4058, 1989.4059 • 2 adults; Samba; $2.70144^{\circ} \mathrm{N},-2.40389^{\circ} \mathrm{W} ; 290 \mathrm{~m}$ a.s.l.; M. Lamotte leg.; MNHNRA-1989.4062, $1989.4063 \cdot 2$ adults; Garango; $11.79985^{\circ} \mathrm{N}$, $-0.55053^{\circ} \mathrm{W} ; 280 \mathrm{~m}$ a.s.l.; 18.VI.1962; M. Lamotte leg.; MNHNRA-1995.1901, 1995.1902.

FIELD MATERIAL. - Burkina Faso • 1 subadult (SVL $61.9 \mathrm{~mm}$ ); W National Park, Nangouli swampy valley; $11.89793^{\circ} \mathrm{N}$, 2.0009 $1^{\circ} \mathrm{E} ; 250 \mathrm{~m}$ a.s.1.; 21.VI.2018; H. J. Ayoro leg., under a shrub; hand capture $\bullet 3$ (SVL 95.3-129.5 mm); Kabougou village; $11.96070^{\circ} \mathrm{N}, 1.99742^{\circ} \mathrm{E} ; 280 \mathrm{~m}$ a.s.l.; 22.VI.2018; same collector as for preceding; in a paddy field; hand capture $\bullet 7 \mathrm{ju}$ veniles (SVL 29.1-38.1 mm); the edge of Dori pond, Toroodi; $14.00554^{\circ} \mathrm{N},-0.02405^{\circ} \mathrm{W} ; 280 \mathrm{~m}$ a.s.l.; 24.VIII.2018; same collector as for preceding; under grasses near water body; hand capture 1 ㅇ (SVL $112.5 \mathrm{~mm}$ ); the edge of N'Djomga village pond; $14.07225^{\circ} \mathrm{N},-0.04862^{\circ} \mathrm{W}$; $265 \mathrm{~m}$ a.s.l.; 25.VIII.2018; same collector as for preceding; near water body; hand capture.

LiteratURE REPORTS. - Burkina Faso • Gourma province, Fada N'gourma; $12.06051^{\circ} \mathrm{N}, 0.34913^{\circ} \mathrm{E} ; 300 \mathrm{~m}$ a.s.l. (Mohneke 2011; Mohneke et al. 2011) • Ganzourgou province, Zorgho; $12.2483^{\circ} \mathrm{N}$, $-0.6278^{\circ} \mathrm{W} ; 300 \mathrm{~m}$ a.s.1.; I-III.2008 (Mohneke et al. 2010b; Mohneke 2011; Mohneke et al. 2011).

Description. - 20 specimens studied. A plump, large and compact frog with a short and wide head (Fig. 6E, F). Its skin faintly warty and discontinuous ridges present on back. Measures for four females 95.3-129.5 mm SVL, thus larger than frogs from Benin (Nago et al. 2006) (female $90 \mathrm{~mm}$ and males 106-110 mm). Tympanum moderately large. Limbs relatively short and strong. A large inner metatarsal tubercle present. In life, dorsal colour greyish to green. Dori subadults and juveniles with a greenish colour and a white mediodorsal line. In W National Park, subadults with a dominantly greyish colour with large dark grey spots on the back (Fig. 6E, F). Adult females with olive green or light grey dorsal colouration. Belly white and throat yellow.

REMARKs. - The taxonomy of West African Pyxicephalus Tschudi, 1838 needs revision (Nago et al. 2006; Böhme \& Heath 2018). The West African specimens of this genus were in the past traditionally assigned to $P$. edulis Peters, 1854 which type locality is in Mozambique. The oldest available nomen for West African specimens is Rana maltzanii Boulenger, 1882, a replacement name for Maltzania bufonia Boettger, 1881. At the time of Boulenger (1882), Pyxicephalus Tschudi, 1838 was considered a subjective synonym of the genus Rana Linnaeus, 1758 . Thus Boulenger (1882) considered Maltzania bufonia Boettger, 1881 as a secondary homonym of Rana bufonia Merrem, 1820 (valid as Elachistocleis surinamensis (Daudin, 1802)) (see Article 59.3 of the International Code of zoological Nomenclature for nomina replaced before 1961 for validity), and cannot be used as valid for the West African Pyxicephalus. The epithet Maltzania bufonia, as proposed by Böhme \& Heath (2018), is permanently invalid and cannot be used for this taxon because the replacement name was"in use" (e. g. cited as valid by Loveridge [1950] and Channing et al. [2012] listed in various synonymies of Pyxicephalus adspersus or Rana edulis; but the expression "in use" is quite imprecise). If we follow this taxonomic change, the nomen Rana maltzanii Boulenger, 1882 should be used as the valid name for Pyxicephalus maltzanii (Boulenger, 1882). Rana (Pyxicephalus) reiensis Monard, 1951 from Cameroon would be available if the central African populations proove to be taxonomically distinct. Thus here, we applied the name Pyxicephalus maltzanii to our voucher specimens, although a formal taxonomic revision including detailed morphological and molecular data is still pending.

HABITAT. - This species was captured among grasses close to Dori and N'Djomga ponds. It was also found in Kabougou village near W National Park. Pyxicephalus maltzanii was recorded by gardeners in a banana plantation, vegetable gardens and paddy fields at Dédougou, Koti, Loumila and Koubri. Other authors indicate its presence in arid savannahs where it apparently prefers sand and clay substrates and it spends most of the year buried, appearing only to breed (Perret 1966; Böhme 1975). It is widely distributed in West Africa but rarely recorded; the species is almost everywhere eaten by the local population (Rödel 2000; Nago et al. 2006; Mohneke et al. 2010b; Padial et al. 2013; Böhme \& Heath 2018). 


\section{Tomopterna milletihorsini (Angel, 1922)}

COLLECTION MATERIAL. - There are no voucher specimens available for this species from Burkina Faso although its presence was reported in the East and Central-East in this country in the literature.

LiterATURE REPORTS. - Burkina Faso • Gourma province, Fada $\mathrm{N}^{\prime}$ gourma; $12.06051^{\circ} \mathrm{N}, 0.34913^{\circ} \mathrm{E} ; 300 \mathrm{~m}$ a.s.l. (Mohneke 2011; Mohneke et al. 2011) • Ganzourgou province, Zorgho; $12.2483^{\circ} \mathrm{N}$, $-0.6278^{\circ} \mathrm{W} ; 300 \mathrm{~m}$ a.s.l.; I-III.2008 (Mohneke et al. 2010b; Mohneke et al. 2011).

DESCRIPTION. - Species with a short head, a horizontal pupil, short and strong limbs. Inner metatarsal tubercles large and shovel-shaped, tarsal tubercles usually present. Frog with a feebly warty back skin and smooth ventral skin. Dorsal colour brown to beige or dark brown. Pale dorsolateral lines often present. A white supratympanic ridge. Numerous dark brown, greenish or reddish spots, often with black borders, distinct on head, back and flanks.

REMARKS. - The genus Tomopterna Duméril \& Bibron, 1841 still comprises various undescribed species and needs taxonomic revision (Padial \& De La Riva 2004; Padial et al. 2013). There are 14 species known in this genus and these are also known to be highly cryptic and morphologically similar (Wasonga \& Channing 2013; Wilson \& Channing 2019). The commonly used name for West African populations was Tomopterna cryptotis (Boulenger, 1907) (Lamotte \& Xavier 1981; Rödel 2000; Padial \& De La Riva 2004; Mohneke 2011; Padial et al. 2013; Sow et al. 2017). Ohler \& Frétey (2008) investigated the status of Arthroleptis milletihorsini (Angel, 1922), the type of which was deposited in MNHN collection. According to their examination, the characters did not correspond to the morphological characters of the genus Arthroleptis Smith, 1849 , but rather to the characters of the genus Tomopterna Duméril \& Bibron, 1841. The holotype is a young specimen of $18 \mathrm{~mm} \mathrm{SVL}$. Ohler \& Frétey (2008) allocated the nomen Arthroleptis milletihorsini to Tomopterna, as Tomopterna milletihorsini (Angel, 1922) with the type locality being Kati $12 \mathrm{~km}$ north to Bamako from Mali. We tentatively use this name for West African Tomopterna.

HABITAT. - During our field sampling, the presence of Tomopterna milletihorsini has been reported from Dori and Yakouta zones where gardeners and fishermen reported a frog species which inflate their body as Pyxicephalus maltzanii and is living under the sand. In Koti women indicated its presence as common in their groundnut fields after the harvesting (mostly from November to December). Women reported that the species was found by young shepherds who search it in sand in dried backwaters or in holes of groundnut fields after harvesting. In West Africa, Tomopterna is found in semiarid to arid habitats on sandy soils in the Sahel zone (Rödel 2000; Padial \& De La Riva 2004; Mohneke 2011). The species has been also found in mountains zones from Mauritania (Padial et al. 2013; Sow et al. 2017).

\section{Family RANIDAE Batsch, 1796}

\section{Amnirana albolabris (west) Jongsma et al. (2018)} (Fig. 8B)

COLleCtiOn MATERIAL. - Burkina Faso • 1 juvenile (SVL $16.1 \mathrm{~mm}$ ); Houet province, in the forest of small-seminary at Nasso; $11.20953^{\circ} \mathrm{N}$, $-4.43951^{\circ} \mathrm{W} ; 340 \mathrm{~m}$ a.s.l.; 4.IV.1968; M. Lamotte leg.; MNHNRA-1999.7575.

DESCRIPTION. - 1 specimen examined. Rather slender body with a triangular, depressed head and slightly rounded snout (Fig. 8B).
Dorsal skin finely granular under the magnifying glass; two distinct dorsolateral folds present, from the posterior border of the eye to the sacrum. Dorsal colour dark brown, with few darker brown spots.

Remarks. - The genus Amnirana has been recently revised by Jongsma et al. (2018). Based on molecular data this study restricts the name Amnirana albolabris (Hallowell, 1856) to Central African populations, the populations from West Africa are clearly distinct and they are provisionally named Amnirana albolabris (west) (Jongsma et al. 2018). The type locality given for $A$. albolabris is "West Africa" by Hallowell (1856). However, Jongsma et al. (2018) searched the route of the collector $\mathrm{Du}$ Chaillu of the syntypes, and identified the area "north of the Ogooué River in Gabon" as the type locality. Therefore, following Jongsma et al. (2018), we use for the West African populations the name $A$. albolabris (west) here. A formal description of this taxon is prepared by Rödel and co-workers.

HabitaT. - Amnirana albolabris (west) was collected in a gallery forest. We considered that place of collection could be Kou Forest which we visited in August 2018, what would be the northernmost site of its range. In other parts of its range the species inhabits pristine to heavily degraded rainforests and gallery forests in the savannah zones (Rödel \& Bangoura 2004; Kpan et al. 2014; Onadeko 2016).

\section{Amnirana galamensis (Duméril \& Bibron, 1841)}

Collection material. - Burkina Faso • 1 ㅇ (SVL 62.3 mm); Sanemantenga province, Kossoghin; $13.29944^{\circ} \mathrm{N},-1.05095^{\circ} \mathrm{W}$; 320 m a.s.l.; VII.1962; M. Lamotte leg.; MNHN-RA-1995.5766 - $1 \mathrm{O}^{\top}(\mathrm{SVL} 61.3 \mathrm{~mm})$; Samba; $12.70144^{\circ} \mathrm{N},-2.40390^{\circ} \mathrm{W} ; 290 \mathrm{~m}$ a.s.l.; 13.VII.1962; M. Lamotte leg.; MNHN-RA-2006.2754・1 1 ? (SVL $73.6 \mathrm{~mm}$ ), $1 \mathrm{O}^{\text {7 }}$ (SVL $69.3 \mathrm{~mm}$ ); Sanemantenga province, Vourbira (current name Gouropila); $12.72553^{\circ} \mathrm{N},-1.75252^{\circ} \mathrm{W} ; 310 \mathrm{~m}$ a.s.l.; 10.VII.1961; M. Lamotte leg.; MNHN-RA-2006.2759, 2006.2750 - 1 subadult (SVL $41.1 \mathrm{~mm}$ ); Fada N'Gourma; $12.06051^{\circ} \mathrm{N}$, $0.34910^{\circ} \mathrm{E} ; 290 \mathrm{~m}$ a.s.l.; II.1983; H. Meyer leg.; ZFMK 38700.

Field MATERIAL. - Burkina Faso • $60^{7}$ (SVL 63.8-66.7 mm), 2 ○ (SVL 70.0-71.9 mm); Pabré dam; $12.51122^{\circ} \mathrm{N},-1.59225^{\circ} \mathrm{W}$; $290 \mathrm{~m}$ a.s.l.; 10.VII.2017; H. J. Ayoro \& A. Ohler leg.; around the irrigation ditches; hand capture $11 \mathrm{O}^{\text {" }}$ (SVL $68.6 \mathrm{~mm}$ ); Koubri, "Ancien barrage"; $12.22843^{\circ} \mathrm{N},-1.34766^{\circ} \mathrm{W} ; 280 \mathrm{~m}$ a.s.l.; 16.VII.2017; same collectors as for preceding; near water body; hand capture • $1 \mathrm{O}^{7}$ (SVL $55.1 \mathrm{~mm}$ ), 8 subadults (SVL 27.6-44.8 mm); Deux Balés National Park, around "Baignade des Eléphants"; $11.71809^{\circ} \mathrm{N},-2.83793^{\circ} \mathrm{W} ; 270$ m a.s.l.; 8.XI.2017; H. J. Ayoro leg.; under dry grasses near water body; hand capture $\bullet 3$ subadults (SVL $37.4-46.1 \mathrm{~mm}$ ); Tiona pond; $11.63241^{\circ} \mathrm{N},-2.85437^{\circ} \mathrm{W}$; $265 \mathrm{~m}$ a.s.l.; 9.XI.2017; same collector as for preceding; hand capture - 2 9 (SVL 54.3-68.1 mm); Mouhoun River bank; $11.77879^{\circ} \mathrm{N}$, $-2.91244^{\circ} \mathrm{W} ; 245 \mathrm{~m}$ a.s.l.; $10 . \mathrm{XI} .2017$; same collector as for preceding; near water body; hand capture $\bullet 1$ subadult (SVL $41.6 \mathrm{~mm}$ ); the backwater of Koti; $11.38206^{\circ} \mathrm{N},-3.05143^{\circ} \mathrm{W} ; 305 \mathrm{~m}$ a.s.l.; 23.X.2017; same collector as for preceding; in a small water well; hand capture $11 \mathrm{O}^{\prime \prime}$ (SVL $54.1 \mathrm{~mm}$ ); Arly National Park, the central forest post office; $11.57532^{\circ} \mathrm{N}, 1.45443^{\circ} \mathrm{E} ; 190 \mathrm{~m}$ a.s.l.; 16.VI.2018; same collector as for preceding; on a trail; hand capture 20 " (SVL 58.3-61.5 mm), 3 \% (SVL 64.7-73.5 mm); W National Park, Kabougou River; $11.96860^{\circ} \mathrm{N}, 2.01259^{\circ} \mathrm{E} ; 280 \mathrm{~m}$ a.s.l.; 18.VI.2018; same collector as for preceding; in a paddy field; hand capture 20 " (SVL57.9-65.3 mm), 1 \% (SVL $62.9 \mathrm{~mm}$ ); the protected part of Kabougou River; $11.97060^{\circ} \mathrm{N}, 2.01627^{\circ} \mathrm{E} ; 265 \mathrm{~m}$ a.s.l.; 19.VI.2018; same collector as for preceding; under grasses; hand capture $200^{\prime \prime}$ (SVL 64.3-65.7 mm), 1 9 (SVL $64.1 \mathrm{~mm}$ ); around PK-27 bouli; $11.88744^{\circ} \mathrm{N}, 2.11913^{\circ} \mathrm{E} ; 265 \mathrm{~m}$ a.s.l.; 20.VI.2018; same collector as for preceding; near water body; hand capture $120^{7}$ (SVL59.4$60.1 \mathrm{~mm}$ ); Nangouli swampy valley; $11.89793^{\circ} \mathrm{N}, 2.00091^{\circ} \mathrm{E}$; 
$250 \mathrm{~m}$ a.s.l.; 21.VI.2018; same collector as for preceding; under grasses; hand capture 4 o" (SVL 68.9-.3 mm), 1 \% (SVL $75.6 \mathrm{~mm})$; the flooded zone of the Comoé River (300 m west of Comoé bridge); $9.93239^{\circ} \mathrm{N},-4.60655^{\circ} \mathrm{W} ; 220 \mathrm{~m}$ a.s.1.; 5.VIII.2018; H. J. Ayoro \& A. Ohler leg.; under shrubs near water body; hand capture $\bullet 3$ juveniles (SVL 26.0-27.0 mm); the edge of Dori pond, Toroodi; $11.96092^{\circ} \mathrm{N}, 1.99709^{\circ} \mathrm{W} ; 280 \mathrm{~m}$ a.s.l.; 23.VIII.2018; H. J. Ayoro leg.; near water body; hand capture - Djikologo, close to Bontioli reserve; $10.93684^{\circ} \mathrm{N},-3.13800^{\circ} \mathrm{W} ; 260 \mathrm{~m}$ a.s.l.; J. Penner leg. - Dano; $11.16601^{\circ} \mathrm{N},-3.08691^{\circ} \mathrm{W} ; 340 \mathrm{~m}$ a.s.l.; 2011; J. Penner leg.; field observation.

Literature RePORTS. - Burkina Faso • Bobo-Dioulasso, Dahora; coordinates not available; 14.VI.1992 (Böhme et al. 1996) • Gourma province, Fada N'gourma; $12.06051^{\circ} \mathrm{N}, 0.34913^{\circ} \mathrm{E} ; 300 \mathrm{~m}$ a.s.l.; II.1983, I-III.2008 (Böhme et al. 1996; Mohneke et al. 2011) • Ganzourgou province, Mogtedo; $12.31844^{\circ} \mathrm{N},-0.83601^{\circ} \mathrm{W} ; 280 \mathrm{~m}$ a.s.l. (Mohneke 2011; Mohneke et al. 2011) • Zorgho; $12.2483^{\circ} \mathrm{N}$ $-0.6278^{\circ} \mathrm{W} ; 300 \mathrm{~m}$ a.s.l.; I-III.2008 (Mohneke 2011; Mohneke et al. 2011) • Houet province, Karankasso Vigué; $11.00982^{\circ} \mathrm{N}$, $-3.90001^{\circ} \mathrm{W} ; 300 \mathrm{~m}$ a.s.l.; 1985 (Böhme \& Heath 2018).

DESCRIPTION. - 51 specimens studied. Males 54.1-71.3 $\mathrm{mm}$ and females 54.3-75.6 mm. Body moderately wide and a wide head. Snout relatively pointed; skin smooth, but flat warts present on flanks and the posterior part of the back. Easily recognized by the colour pattern and distinct, broad white or yellow dorsolateral ridges (Rödel 2000). Colouration in alcohol dark brown with two white dorsolateral ridges and some grey spots on the limbs. Belly white. Males with a pair of lateral vocal sacs and large glands on the dorsal side of the upper arm.

HabitAT. - We recorded A. galamensis in many habitats, i.e. agricultural zones, in water filled depressions of shrubby, grassy and wooded savannah. During the rainy season, we encountered the species around ponds and small water bodies in areas with sand and clay. subadult specimens were caught between cracks and small hollows at the edge of a permanent pond. The species occurs mostly along more permanent, larger waters in humid and dry savannah, including agricultural areas (Rödel 2000). In the dry season, this species can be found along river banks. The distribution area of the species, as currently understood, extends from extreme western Africa across to the horn of Africa and south into Angola, Mozambique, Zambia and Zimbabwe (Rödel \& Bangoura 2004; Segniagbeto et al. 2007; Mohneke et al. 2011; Onadeko 2016; Böhme \& Heath 2018). However, results by Jongsma et al. (2018) indicate that East African populations are not conspecific with those from West Africa.

\section{SPECIMEN WITH DOUBTFUL ORIGIN IN BURKINA FASO}

\section{Sclerophrys mauritanica (Schlegel, 1841)} (Fig. 7C)

Collection MATERIAL. - Burkina Faso • 1 9 (SVL $104 \mathrm{~mm}$ ) Boulgou province, Garango; $11.79979^{\circ} \mathrm{N},-0.55053^{\circ} \mathrm{W} ; 280 \mathrm{~m}$ a.s.l.; 18.VI.1962; M. Lamontellerie leg.; MNHN-RA-1989.4038.

DESCRIPTION. - 1 specimen studied. Dorsum yellowish with large brown patches, bordered with black (Fig. 7A). Tympanum large and interorbital space concave. Parotoid glands kidney-shaped and parallel. Presence of double subarticular tubercles on the fourth toe. Characters corresponding to Salvador's (1996) description of Sclerophrys mauritanica for northern Africa.

HaвITAт. - This toad is known from a wide variety of habitats, including rocky areas, grasslands, Mediterranean zones, oases, agricultural lands and urban areas (Salvador 1996; Ben Hassine \& Nouira 2012). This species is reported from throughout northern
Africa in an apparently continuous distribution between the Tunisian and Moroccan borders (Geniez et al. 2000; Ben Hassine \& Escoriza 2017; Escoriza \& Ben Hassine 2019). The presence of this species was reported by Lamotte \& Xavier (1981) from Sub-Saharan areas like Burkina Faso but these authors did not mention any voucher specimens. The specimen of $S$. mauritanica in the MNHN is labelled as having been collected at Garango, in central-east of Burkina Faso, in VI.1962 by Michel Lamontellerie (1928-2013). The collector was an army doctor and stayed for over 20 years in this place. 109 specimens donated by Lamontellerie are present in the MNHN collections coming from Burkina Faso, Mali and France, but none from northern Africa. Nevertheless the collection locality of $S$. mauritanica in Burkina Faso should be regarded with some doubt, as it is more than $1000 \mathrm{~km}$ outside its southern range limit. Future research should carefully check toads from Burkina Faso, but also northern Mali and Niger for the potential presence of this species, south of the Sahara.

\section{DISTRIBUTION PATTERNS OF AMPHIBIANS IN BURKINA FASO} In Tables $2 \& 3$, we represent all amphibian species recorded from Burkina Faso with their habitat type and the source of the record (Table 2). The species in the Sudanian and Sub-Sudanian zones were more diverse than those in the Sahelian zone, e.g. only 12 species recorded in Dori and Yakouta compared to many other study sites (Table 3). Some amphibian families such as Arthroleptidae and Michrohylidae were absent from the Sahelian area (Dori and Yakouta). The Hyperoliidae were represented there by a single species, Kassina senegalensis. Most of the 36 species reported here can inhabit both disturbed and undisturbed areas. However three taxa, Arthroleptis poecilonotus, Hyperolius concolor concolor and Xenopus tropicalis, had more specific habitat requirements, i.e. gallery forest. This most likely also applies to Amnirana albolabris (west).

\section{DISCUSSION}

This study, which combines collection data, recent field data and literature information attempted to summarize the known amphibian species of Burkina Faso. Most amphibian records were from the western (Cascades, Haut-Bassins and Sud-Ouest Regions), central (Centre, Centre-Est and Centre-Sud Regions) and eastern parts (Est Region) of Burkina Faso (Fig. 1). This is likely due to the fact that these regions comprise the majority of protected areas and are more humid than the dry north, which however, is also less well explored. In the rural area (Pabré, Loumbila, Koubri) 21 species were recorded during field work, but these species are not uniformly distributed on these three small sites. The variation in faunal composition may be related to the soil composition (i.e. concerning water holding capacity and the possibility to dig into the soil) and human activities on each site. Irrigation was practiced on all three sites; the banks of Loumbila dam have a soil dominated by gravel and lateritic stones, Pabré and Koubri sites are dominated by a mixture of clay and gravel. In Arly and W National Park, 22 species were recorded and in Comoé-Léraba Forest 23 species have been identified. In these sites, the species number thus was more or less equal, meaning that a large number of species occur in protected and unprotected areas. This is not unusual as most savannah 
TABLE 2. - Habitat and distribution of amphibian species from Burkina Faso. Abbreviations: ANP, Arly National Park; WNP, W National Park; 2BNP, Deux Balés National Park; D-Y, Dori and Yakouta area; FCL, Comoé-Léraba Forest; FK, Kou Forest, R-A, Rural areas (Pabré, Koubri and Loumbila). Symbols: $\times$ (habitats), presence of species; $\times$ (localities), reported in one locality; xx, reported in many localities. Literature records: 1, Böhme \& Heath 2018; 2, Böhme et al. 1996; 3, Brito et al. 2008; 4, Lamotte \& Ohler 1997; 5, Lamotte 1967b; 6, Loumont 1984; 7, Mohneke et al. 2010a; Mohneke et al. 2010b; 8, Mohneke et al. 2011; 9 , Mohneke 2011; 10, Penner, unpublish. data; 11, Rödel \& Moritz, unpublish. data; 12, Schiøtz 1967.

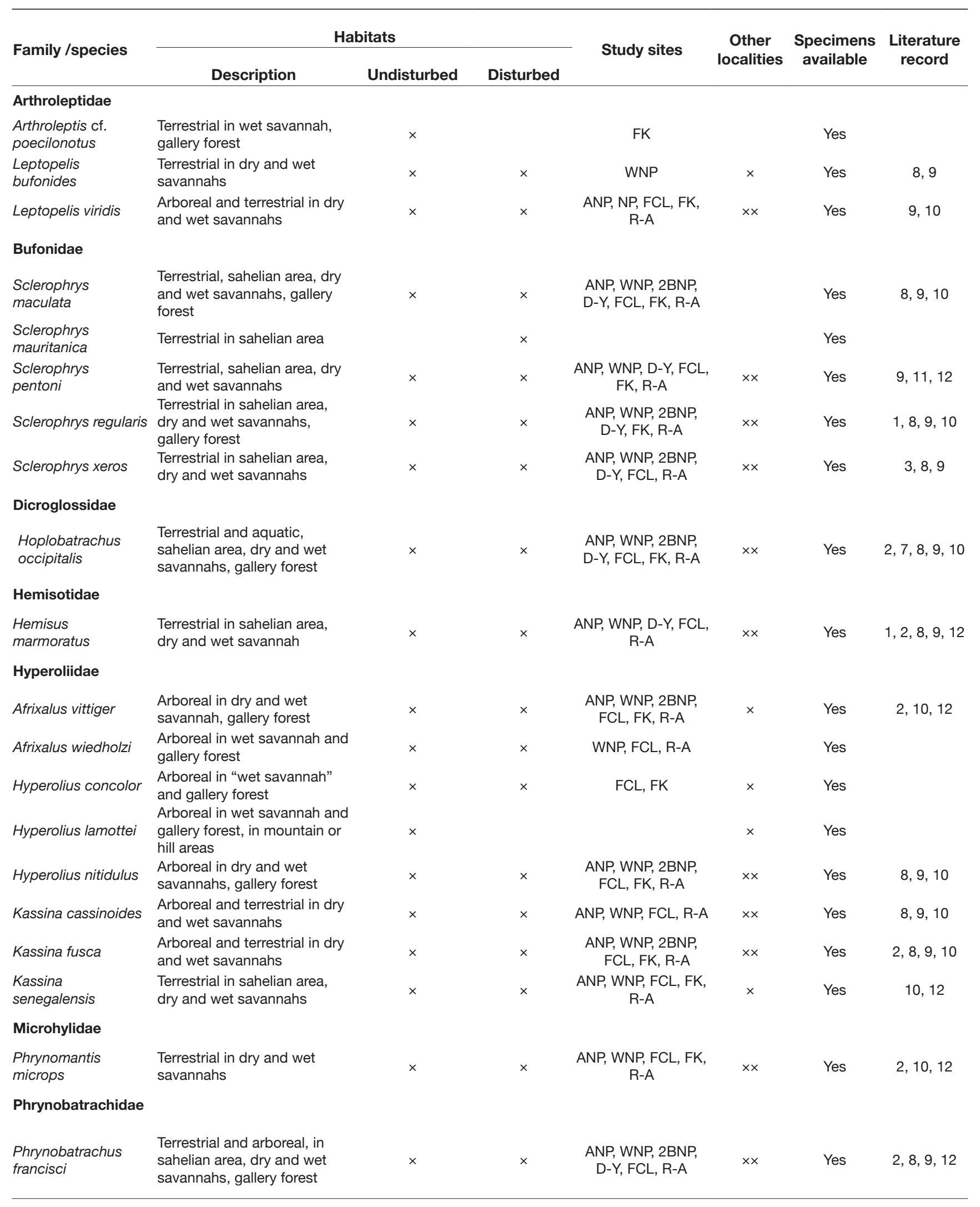


Table 2. - Continuation

\begin{tabular}{|c|c|c|c|c|c|c|c|}
\hline \multirow{2}{*}{ Family /species } & \multicolumn{3}{|c|}{ Habitats } & \multirow{2}{*}{ Study sites } & \multirow{2}{*}{$\begin{array}{c}\text { Other } \\
\text { localities }\end{array}$} & \multirow{2}{*}{$\begin{array}{l}\text { Specimens } \\
\text { available }\end{array}$} & \multirow{2}{*}{$\begin{array}{l}\text { Literature } \\
\text { record }\end{array}$} \\
\hline & Description & Undisturbed & Disturbed & & & & \\
\hline $\begin{array}{l}\text { Phrynobatrachus } \\
\text { latifrons }\end{array}$ & $\begin{array}{l}\text { Terrestrial and arboreal, in dry } \\
\text { and wet savannahs, gallery } \\
\text { forest }\end{array}$ & $x$ & $x$ & $\begin{array}{l}\text { ANP, WN, 2BNP, } \\
\text { FCL, R-A }\end{array}$ & $x$ & Yes & \\
\hline \multicolumn{8}{|l|}{ Pipidae } \\
\hline Xenopus fischbergi & $\begin{array}{l}\text { Aquatic in dry and wet } \\
\text { savannahs, gallery forest }\end{array}$ & $x$ & $\mathrm{X}$ & $\mathrm{R}-\mathrm{A}$ & $X X$ & Yes & $6,8,9$ \\
\hline Xenopus tropicalis & Aquatic in gallery forest & $\mathrm{X}$ & & FK & $x$ & Yes & $1,2,10$ \\
\hline \multicolumn{8}{|l|}{ Ptychadenidae } \\
\hline Hildebrantia ornata & $\begin{array}{l}\text { Terrestial in dry and wet } \\
\text { savannahs }\end{array}$ & $x$ & $\mathrm{X}$ & ANP, WNP, FCL, R-A & $x X$ & Yes & 8,9 \\
\hline Ptychadena bibroni & $\begin{array}{l}\text { Terrestrial in sahelian zone, } \\
\text { dry and wet savannahs, } \\
\text { gallery forest }\end{array}$ & $\mathrm{X}$ & $\mathrm{X}$ & $\begin{array}{c}\text { ANP, WNP, 2BNP, } \\
\text { FCL, R-A }\end{array}$ & $X X$ & Yes & $2,4,8,9,10$ \\
\hline $\begin{array}{l}\text { Ptychadena } \\
\text { mascareniensis }\end{array}$ & $\begin{array}{l}\text { Terrestial in dry and wet } \\
\text { savannahs }\end{array}$ & $\mathrm{X}$ & $\mathrm{X}$ & ANP, 2BNP, FCL & $x$ & Yes & 8,9 \\
\hline $\begin{array}{l}\text { Ptychadena } \\
\text { oxyrhynchus }\end{array}$ & $\begin{array}{l}\text { Terrestial in dry and wet } \\
\text { savannahs }\end{array}$ & $\mathrm{X}$ & $\mathrm{X}$ & & $X X$ & Yes & 8,9 \\
\hline Ptychadena pumilio & $\begin{array}{l}\text { Terrestrial in sahelian zone, } \\
\text { dry and wet savannahs, } \\
\text { gallery forest }\end{array}$ & $\mathrm{X}$ & $\mathrm{X}$ & $\begin{array}{l}\text { ANP, WNP, 2BNP, } \\
\text { D-Y, FCL, FK, R-A }\end{array}$ & $X X$ & Yes & $5,8,9$ \\
\hline $\begin{array}{l}\text { Ptychadena } \\
\text { schillukorum }\end{array}$ & Terrestrial in wet savannah & $x$ & $x$ & ANP & $x$ & Yes & 8,9 \\
\hline Ptychadena tellinii & $\begin{array}{l}\text { Terrestrial in dry and wet } \\
\text { savannahs, gallery forest }\end{array}$ & $x$ & $x$ & ANP, 2BNP, R-A & $x x$ & Yes & $8,9,11$ \\
\hline Ptychadena tournieri & $\begin{array}{l}\text { Terrestrial in dry and wet } \\
\text { savannahs, gallery forest }\end{array}$ & $x$ & $x$ & & $x$ & No & 8,9 \\
\hline Ptychadena trinodis & $\begin{array}{l}\text { Terrestrial in sahelian zone, } \\
\text { dry and wet savannahs, } \\
\text { gallery forest }\end{array}$ & $\mathrm{X}$ & $\mathrm{X}$ & ANP, 2BNP, D-Y, FCL & $X X$ & Yes & 8,9 \\
\hline \multicolumn{8}{|l|}{ Pyxicephalidae } \\
\hline $\begin{array}{l}\text { Tomopterna } \\
\text { milletihorsini }\end{array}$ & $\begin{array}{l}\text { Terrestrial in sahelian zone, } \\
\text { dry and wet savannahs }\end{array}$ & $x$ & $\mathrm{x}$ & & $X X$ & No & 8,9 \\
\hline $\begin{array}{l}\text { Pyxicephalus } \\
\text { maltzanii }\end{array}$ & $\begin{array}{l}\text { Terrestrial in sahelian zone, } \\
\text { dry and wet savannahs, } \\
\text { gallery forest }\end{array}$ & $x$ & $x$ & WNP, D-Y, R-A & $x X$ & Yes & $7,8,9$ \\
\hline \multicolumn{8}{|l|}{ Ranidae } \\
\hline $\begin{array}{l}\text { Amnirana albolabris } \\
\text { (west) }\end{array}$ & $\begin{array}{l}\text { Arboreal and terrestrial, in } \\
\text { wet savannah, gallery forest }\end{array}$ & $x$ & & & $x$ & Yes & \\
\hline Amnirana galamensis & $\begin{array}{l}\text { Terrestrial in sahelian zone, } \\
\text { dry and wet savannahs, } \\
\text { gallery forest }\end{array}$ & $\mathrm{X}$ & $x$ & $\begin{array}{l}\text { ANP, WNP, 2BNP, } \\
\text { D-Y,FCL, R-A }\end{array}$ & $X X$ & Yes & $2,8,9,10$ \\
\hline
\end{tabular}

sites and extensively used areas within that zone offer very similar habitats for savannah dwelling amphibian species. The three sites (Arly and W National Park, Comoé-Léraba Forest) are situated in the Sudanian and Sub-Sudanian zones (Fontès \& Guinko 1995), which are dominated by grassland, tree and shrubs savannahs. Within the semi-urban area dams and artificial ponds may offer suitable habitats for man and amphibian species, as well as for other plants and animals (Ganaba 2005).

In the northern, Sahelian part of the country still quite a few species could be recorded. In Dori and Yakouta 12 species belonging to 7 families were listed (Tables 2,3). These
Sahelian sites are dominated by shrub and steppe savannahs, most thorny shrubs (Fontès \& Guinko 1995). Herbaceous vegetation which may offer suitable microclimate and hiding places for amphibians is scarce, and the area is intensively used for cattle and fields. Therefore, except Kassina senegalensis, arthroleptids, hyperoliids and microhylids were absent in this part of Burkina Faso.

Summarizing all knowledge from recent and historical sites, vouchers and literature records, 36 amphibian species have become known from Burkina Faso: Arthroleptis poecilonotus, Leptopelis bufonides, L. viridis, Sclerophrys maculata, S. pentoni, S. regularis, S. xeros, Hoplobatrachus occipitalis, Hemisus 
TABLE 3. - List of amphibian recently studied sites in Burkina Faso, the habitat characteristics, administrative regions and phytogeographic zones.

\begin{tabular}{|c|c|c|c|c|c|}
\hline $\begin{array}{l}\text { Recent study } \\
\text { sites }\end{array}$ & $\begin{array}{l}\text { Sampling } \\
\text { period }\end{array}$ & Habitat characteristics & Provinces & $\begin{array}{l}\text { Administrive } \\
\text { Regions }\end{array}$ & $\begin{array}{l}\text { Phytogeographic } \\
\text { zones }\end{array}$ \\
\hline $\begin{array}{l}\text { Deux Balés } \\
\text { National Park }\end{array}$ & November & $\begin{array}{l}\text { Undisturbed zone; grassland, tree, woodland and } \\
\text { shrubs savannahs, gallery forest; no agricultural and } \\
\text { pastoral practices. }\end{array}$ & Balés and Tuy & $\begin{array}{l}\text { Boucle du } \\
\text { Mouhoun and } \\
\text { Haut-Bassins }\end{array}$ & Sub-Sudanian \\
\hline Dédougou & $\begin{array}{l}\text { August and } \\
\text { September }\end{array}$ & $\begin{array}{l}\text { Disturbed zone; grassland, tree and shrubs savannahs; } \\
\text { near habitations, farm fields. }\end{array}$ & Mouhoun & $\begin{array}{l}\text { Boucle du } \\
\text { Mouhoun }\end{array}$ & \multirow{2}{*}{ Sudanian } \\
\hline Djibasso & $\begin{array}{l}\text { August and } \\
\text { September }\end{array}$ & $\begin{array}{l}\text { Disturbed zone; grassland and shrubs savannahs; near } \\
\text { and in habitations, irrigated zone. }\end{array}$ & Kossi & $\begin{array}{l}\text { Boucle du } \\
\text { Mouhoun }\end{array}$ & \\
\hline $\begin{array}{l}\text { Comoé-Léraba } \\
\text { Forest }\end{array}$ & August & $\begin{array}{l}\text { Undisturbed zone; grassland, tree, woodland and } \\
\text { shrubs savannahs, gallery forest; no human activities in } \\
\text { this forest but around it. }\end{array}$ & $\begin{array}{l}\text { Comoé and } \\
\text { Léraba }\end{array}$ & Cascades & Sub-Sudanian \\
\hline Kou Forest & August & $\begin{array}{l}\text { Undisturbed zone; tree and woodland savannahs, } \\
\text { gallery forest; strictly protected area. }\end{array}$ & Houet & Haut-Bassins & \multirow{2}{*}{ Sub-Sudanian } \\
\hline Koti & $\begin{array}{l}\text { August to } \\
\text { November }\end{array}$ & $\begin{array}{l}\text { Disturbed zone; grassland, tree and shrub savannahs; } \\
\text { near farm field, irrigated and habitation areas. }\end{array}$ & Tuy & Haut-Bassins & \\
\hline $\begin{array}{l}\text { Loumbila dam } \\
\text { Pabré dam } \\
\text { Koubri dams }\end{array}$ & July & $\begin{array}{l}\text { Disturbed zone; peri-urban areas; grassland, tree } \\
\text { and shrub savannahs; near irrigated and farm fields, } \\
\text { habitations, no intensive pasture. }\end{array}$ & $\begin{array}{l}\text { Oubritenga } \\
\text { Kadiogo } \\
\text { Kadiogo }\end{array}$ & $\begin{array}{l}\text { Pateau-Central } \\
\text { Centre } \\
\text { Centre }\end{array}$ & Sudanian \\
\hline Arly National Park & March and June & $\begin{array}{l}\text { Undisturbed zone; grassland, tree, woodland and shrub } \\
\text { savannahs, gallery forest; no agricultural and pastoral } \\
\text { practices in this park. }\end{array}$ & $\begin{array}{l}\text { Tapoa and } \\
\text { Kompienga }\end{array}$ & $\begin{array}{l}\text { Est and Centre- } \\
\text { Est }\end{array}$ & Sub-Sudanian \\
\hline W National Park & $\begin{array}{l}\text { February and } \\
\text { June }\end{array}$ & $\begin{array}{l}\text { Undisturbed zone; grassland, tree, woodland and shrub } \\
\text { savannahs, gallery forest; no agricultural and pastoral } \\
\text { practices in this park but around it. }\end{array}$ & Tapoa & Est & $\begin{array}{l}\text { Between Sudanian } \\
\text { and Sub-Sudanian }\end{array}$ \\
\hline Dori - Yakouta & August & $\begin{array}{l}\text { Disturbed zone; peri-urban areas; shrub savannah and } \\
\text { steppe; farm field, intensive pasture. }\end{array}$ & Séno & Sahel & Sahelian \\
\hline
\end{tabular}

marmoratus, Afrixalus vittiger, A. weidholzi, Hyperolius concolor concolor, $H$. lamottei, $H$. nitidulus, Kassina cassinoides, $K$. fusca, K. senegalensis, Phrynomantis microps, Phrynobatrachus francisci, P. latifrons, Xenopus fischbergi, X. tropicalis, Hildebrandtia ornata, Ptychadena bibroni, P. mascareniensis, P. oxyrhynchus, P. pumilio, P. schillukorum, P. tellinii, $P$. tournieri, $P$. trinodis, Pyxicephalus maltzanii, Tomopterna milletihorsini, Amnirana albolabris (west) and $A$. galamensis. Seven species were new records for Burkina Faso and confirmed by voucher specimens: Arthroleptis poecilonotus, Afrixalus vittiger, Afrixalus weidholzi, Hyperolius lamottei, Kassina cassinoides, Ptychadena schillukorum and Amnirana albolabris (west). These new records include some species which have their northernmost records in Burkina Faso and are rare. These were namely Arthroleptis poecilonotus, Hyperolius lamottei, Xenopus tropicalis and Amnirana albolabris (west). These four latter species are widespread in humid savannahs and even forests in countries south of Burkina Faso and only migrate in Burkina along dense gallery forests of larger rivers. A total of 31 species were recorded during recent field work from July 2017 to September 2018. These new collections included Arthroleptis poecilonotus and Xenopus tropicalis. Species such as Hyperolius lamottei and Tomopterna milletihorsini have not been recently confirmed. We believe that these two species still prevail in Burkina Faso. Hyperolius lamottei presumably could be recorded on moist inselberg vegetation in the southern part of Burkina Faso, close to Ivory Coast and Guinea (see Rödel \& Ernst 2003). Tomopterna milletihorsini may be widespread in the dry north. Regarding the short activity period for T. milletihorsini, likely only after heavy rain (see its habitat above) and the special habitat needs of H. lamottei (Schiøtz 1999; Rödel 2000; Rödel \& Ernst 2003; Rödel et al. 2004), these species will need especially dedicated surveys to detect them.

The record of Sclerophrys mauritanica is likely a mistake, as all other records of the species are from oasis in or locations north of the Sahara (Salvador 1996; Ben Hassine \& Escoriza 2017; Escoriza \& Ben Hassine 2019). However, Lamotte \& Xavier (1981), mentioned that few specimens can be found in the sub-Saharan areas of West Africa. Phylogenetically this toad has its closest relatives south of the Sahara, thus biogeographical linkage with the southern species must have existed at least in geological times. A single specimen is present in the MNHN collection and labelled to be collected at Garango in June 1962 near Tenkodogo. Three other amphibian species (Xenopus fischbergi, Sclerophrys regularis and Pyxicephalus maltzanii) were collected from this locality by the same collector. In summary we consider the Burkinabe origin of the voucher to be doubtful.

This study shows that Burkinabe amphibian fauna is more diverse than previously indicated; 17 species have been listed by Mohneke et al. (2010a) and 25 species have been recorded for the Gourma and Ganzourgou regions (Mohneke 2011). Today, 36 species belonging to eleven families have been recorded. As can be expected from a country without any moist forest, this number is still much lower compared to some southern neighbours of Burkina Faso: Benin: 51; Ivory Coast: 96; Ghana: 83; Togo: 54 (Rödel et al. 2010b; Nago et al. 2010). If we consider countries with a habitat range similar to that of Burkina Faso, e.g. Mali (33 amphibian species) and Niger (20 species) (Frost 2019), the number of amphibian 
species recorded from Burkina Faso seems very reasonable. The overall high number of amphibian species is mainly due to the richness of relatively humid habitats along rivers and permanent water bodies (lakes, ponds) in the western, central and eastern parts of Burkina Faso.

\section{Acknowledgements}

The first author would like to acknowledge the Cultural Service of Cooperation Action (SCAC) of the French embassy in Ouagadougou for its financial support during her internship at the Muséum national d'Histoire naturelle (MNHN) in Paris. All the authors are grateful to the curators from various museums (MHNG, MVZ and ZFMK) for loans of Burkinabe amphibian specimens and their sincere collaboration. They are grateful in particular to the International Foundation for Science (IFS) for their financial support during field work. The Direction de la Faune et des Ressources Cynétiques (DFRC), the Office National des Aires Protégées (OFINAP) and the Association inter-villageoise de Gestion des Ressources Naturelles et de la Faune de la Comoé-Léraba (AGEREF/CL), all in Burkina Faso, are acknowledged for helping us to get easy access to sites from national parks. Acknowledgements are addressed to Thierry Frétey, and Yves Boussicot, Jérôme Courtois, Marc Cugnet and Laure Pierre from the Reptiles and Amphibians collection and Victoire Koyamba from the Reptiles and Amphibian library at the MNHN for their valuable assistance.

The authors of this manuscript thank the reviewers for agreeing to read it and contribute to it.

\section{REFERENCES}

Adeba P. J., Kouassi P. \& Rödel M.-O. 2010. — Anuran amphibians in a rapidly changing environment - revisiting Lamto, Côte d'Ivoire, 40 years after the first herpetofaunal investigations. African Journal of Herpetology 59: 1-16. https://doi. org/10.1080/04416651003595337

Akoudjin M., Kiema S., Sangare M., Cesar J., Bouyer J. \& KABORÉ-ZOUNGRANA C. 2016. — Influence des activités agricoles sur la végétation le long d'un gradient pluviométrique nord-sud du Burkina Faso. Vertigo. La revue électronique en Sciences de l'Environnement 16: 1-19. https://doi.org/10.4000/vertigo.17015

AMIET J. L. 1974. - Voix d'amphibiens camerounais. IV. Raninae: genres Ptychadena, Hildebrandtia et Dicroglossus. Annales de la Faculté des Sciences du Cameroun 18: 109-128.

Amiet J. L. 2012. — Les rainettes du Cameroun. Édition J. L. Amiet et La Nef des Livres, Nyons \& Saint Nazaire, France, 591 p.

Baillie J. E. M., Griffiths J., Turvey S. T., LOH J. \& Collen B. 2010. - Evolution lost: status and trends of the world's vertebrates. Zoological Society of London, United Kingdom, 72 p.

BARBAULT R. \& TREFAUT RODRIGUES M. 1979. — Observations sur la reproduction et la dynamique des populations de quelques anoures tropicaux III. Arthroleptis poecilonotus. Tropical Ecology 20: 64-77.

Barej M. F., Sandberger-Loua L., Doumbia J., Kouamé N. G., RÖDEL M.-O. \& PenNER J. 2017. - Microhylidae: Phrynomantis microps (Peters, 1875), West African rubber frog in Guinea. African Herp News 64: 37-39.

Ben Hassine J. \& Escoriza D. 2017. - Amphibians of Algeria: new data on the occurrence and natural history. Herpetological Bulletin 142: 6-18.
Ben Hassine J. \& Nouira S. 2012. - The amphibians of Tunisia: Biodiversity, distribution, status and majors threats. Froglog 101: 32-34.

BLACKBURN D. C. 2009. - Diversity and evolution of male secondary sexual characters in African squeakers and long-fingered frogs. Biological Journal of the Linnean Society 96: 553-573. https://doi. org/10.1111/j.1095-8312.2008.01138.x

BLACKBURN D. C. 2010. - A new squeaker frog (Arthroleptidae: Arthroleptis) from Bioko Island, Equatorial Guinea. Herpetologica 66: 320-334. https://doi.org/10.1655/09-039.1

Blackburn D. C., Gvoždík V. \& Leaché A. D. 2010. — A new squeaker frog (Arthroleptidae: Arthroleptis) from the mountains of Cameroon and Nigeria. Herpetologica 66: 335-348. https:// doi.org/10.1655/HERPETOLOGICA-D-10-00015.1

BÖHME W. 1975. - Zur Herpetofaunistik Kameruns, mit Beschreibung eines neuen Scinciden. Bonner zoologische Beiträge 26: 1-48.

BÖHME W. 2005. - Presence of Kassina cassinoides (Boulenger, 1903) in Senegal. Herpetozoa 18: 177-178.

BÖHME W. \& HEATH J. 2018. - Amphibian and reptilian records from south-central Mali and western Burkina Faso. Bonn zoological Bulletin 67: 59-69.

BÖHME W., MeINIG H. \& Rödel M.-O. 1996. — New records of amphibians and reptiles from Burkina Faso and Mali. British herpetological Society Bulletin 56: 7-26.

BOULENGER 1882. - Catalogue of the Batrachia Salientia S. Ecaudata in the collection of the British Museum. Taylor \& Francis, London, i-xvi + 1-503, pl. 1-30. https://doi.org/10.5962/bhl. title. 8307

Bourgat R. 1979. - Trématodes d'Amphibiens du Togo. Bulletin du Muséum national d'Histoire naturelle 3: 597-624.

Brito J. C., Rebelo H., Crochet P. A. \& Geniez P. 2008. — Data on the distribution of amphibians and reptiles from North and West Africa, with emphasis on Acanthodactylus lizards and the Sahara Desert. Herpetological Bulletin 105: 19-27.

Cesar J., Bouyer J., Granjon L., AKoudjin M. \& Louppe D. 2011.— Les relictes forestières de la falaise de Banfora, les dégradations au voisinage de Bobo-Dioulasso, Burkina Faso. Bois et Forêts des Tropiques 308: 5-19. https://doi.org/10.19182/bft2011.308.a20474

Channing A. 2001. - Amphibians of Central and Southern Africa. Cornell University Press, New York, USA, 470 p.

Channing A., Hillers A., LÖtTers S., RÖDEl M.-O., SCHICK S., Conradie W., Rödder D., Mercurio V., Wagner P., Dehling J. M., Du Preez L. H., Kielgast J. \& Burger M. 2013. - Taxonomy of the super-cryptic Hyperolius nasutus group of long reed frogs of Africa (Anura: Hyperoliidae), with descriptions of six new species. Zootaxa 3620: 301-350. https:// doi.org/10.11646/zootaxa.3620.3.1

Channing A. \& Howell K. M. 2006. - Amphibians of East Africa. Cornell University Press, New York, USA, 432 p.

Channing A. \& RöDEl M.-O. 2019. - Field guide to the frogs and other amphibians of Africa. Struik Nature, Cape Town, South Africa, $408 \mathrm{p}$.

ChAnNing A., RÖDEL M.-O. \& ChANNING J. 2012. — Tadpoles of Africa - The biology and identification of all known tadpoles in sub-Saharan Africa. Frankfurt Contributions to Natural History, Edition Chimaira, Vol. 55, Frankfurt/Main, 402 p.

DemBÉLÉ Y. 2010. — Cartographie des zones socio-rurales du Burkina Faso. Rome, Italie, FAO, 68 p.

Escoriza D. \& Ben Hassine J. 2019. - Amphibians of North Africa. Academic Press, London, United Kingdom, 337 p.

Evans B. J., Carter T. F., Greenbaum E., Gvoždík V., Kelley D. B., Mclaughlin P. J., Pauwels O. S. G., Portik D. M., Stanley E. L., Tinsley R. C., Tobias M. L. \& Blackburn D. C. 2015. Genetics, morphology, advertisement calls, and historical records distinguish six new polyploid species of African clawed frog (Xenopus, Pipidae) from West and Central Africa. PLoS ONE 10: e0142823. https://doi.org/10.1371/journal.pone.0142823 
FOnTÈS J. \& GuinKo S. 1995. - Carte de la végétation et de l'occupation du sol du Burkina Faso: Notice explicative. Toulouse, Université Paul Sabatier, Ministère de la Coopération française. Projet campus (8813101).

Frost D. R. 2019. - Amphibian Species of World: an online reference. Version 6.0. Available at htt://research.amnh.org/ herpetology/amphibia/index.html. Accessed on 15 February 2019 and 2 November 2020.

Frost D. R., Grant T., Faivovich J., Bain R. H., Haas A., Haddad C. F. B., De Sá R. O., Channing A., Wilkinson M., Donnellan S. C., Raxworthy C. J., Campbell J. A., Blotto B. L., Moler P., Drewes R. C., Nussbaum R. A., LyNCH J. D., Green D. M. \& Wheeler W. C. 2006. - The amphibian tree of life. Bulletin of the American Museum of Natural History 297: 1-370. https://doi.org/10.1206/00030090(2006)297[0001:TATOL]2.0.CO;2

GANABA S. 2005. - Impact des aménagements de conservation des eaux et des sols sur la régénération des ressources ligneuses en zone sahélienne et nord soudanienne du Burkina Faso. Vertigo, la revue électronique en Sciences de l'Environnement 6: 1-25.

GANABA S. 2008. - Caractérisation, utilisations, tests de restauration et gestion de la végétation sahélienne du Burkina Faso. Thèse de doctorat d'état, université Cheikh Anta Diop (UCAD), Faculté Sciences et Techniques, Dakar, Sénégal, 287 p.

Geniez P., Mateo J. A. \& Bons J. 2000. - A checklist of the amphibians and reptiles of Western Sahara (Amphibia, Reptilia). Herpetozoa 13: 149-163.

Gongomin B. A. I., Kouamé N. G. \& Rödel M.-O. 2019. — New records of the Togo Toad, Sclerophrys togoensis, from south-eastern Ivory Coast. Herpetology Notes 12: 501-508.

Guibé J. \& Lamotte M. 1957. - Révision systématique des Ptychadena (Batraciens Anoures Ranidés) d'Afrique Occidentale. Bulletin de l'Institut fondamental d'Afrique noire, (A) 19:937-1003.

Hallowell E. 1856. - Notes on Reptilia in the collection of the Museum of the Academy of Natural Sciences. Proceedings of the Academy of Natural Sciences of Philadelphia 8: 146-153.

HiRSCHFELd M. \& RöDEl M.-O. 2011. - Variable reproductive strategies of an African savanna frog, Phrynomantis microps (Amphibia, Anura, Microhylidae). Journal of tropical Ecology 27: 601-609. https://doi.org/10.1017/S0266467411000320

Hughes B. 1988. - Herpetology in Ghana (West Africa). British herpetological Society Bulletin 25: 29-38.

Jongsma G. F. M., Barej F. M., Barratt D. C., Burger M., Conradie W., Ernst R., Greenbaum E., Hirschfeld M., Leaché D. A., Penner J., Portik M. D., Zassi-Boulou A. G., Rödel M.-O. \& Blackburn C. D. 2018. - Diversity and biogeography of frogs in the genus Amnirana (Anura: Ranidae) across sub-Saharan Africa. Molecular Phylogenetics and Evolution 120: 274-285. https://doi.org/10.1016/j.ympev.2017.12.006

Kambiré H. W., Djenontin I. N. S., Kabore A., Djoudi H., Balinga M. P. B., Zida M. \& Assembe-Mvondo S. 2015. — La REDD+ et l'adaptation aux changements climatiques au Burkina Faso: causes, agents et institutions. Bogor, Indonésie, 123 p.

Kaminsky S. K., Linsenmair K. E. \& Grafe T. U. 1999. - Reproductive timing, nest construction and tadpole guidance in the African pig-nosed frog, Hemisus marmoratus. Journal of Herpetology 33: 119-123. https://doi.org/10.2307/1565550

Kangoyé N. M. 2013. - Les chauves-souris du Burkina Faso: diversité et distribution. Thèse de doctorat, Université de Ouagadougou, Burkina Faso, $241 \mathrm{p}$.

Konan J. C. B. Y. N., Kouamé N. G., Kouamé A. M., AdepoGourÈnE. A. B. \& RöDEl M.-O. 2016. - Feeding habits of two sympatric rocket frogs (genus Ptychadena) in a forest remnant of southern-central Ivory Coast, West Africa. Entomology, Ornithology and Herpetology 5: 176. https://doi.org/10.4172/21610983.1000176

Kouamé N. G., Konan J. C. B. Y. N., Adepo-Gourène A. B., GourÈnE G. \& RÖDEL M.-O. 2014. - The amphibians of the
Yakassé-Mé village forest, a threatened rainforest of south-eastern Ivory Coast. Herpetology Notes 7: 657-665.

Kpan T. F., Adeba P. J., Kouamé N. G., Kone I., Kouassi P. K. \& RÖDEL M.-O. 2014. - The anuran fauna of a volunteer nature reserve: the Tanoé-Ehy swamp forests, south-eastern Ivory Coast, West Africa. Zoosystematics and Evolution 90: 261-270. https:// doi.org/10.3897/zse.90.8796

LamotTe M. 1967a. — Le problème des Ptychadena (Famille des Ranidae) du groupe mascareniensis dans l'Ouest Africain. Bulletin du Muséum national d'Histoire naturelle, 2ème série 39: 647-656.

LAMOTTE M. 1967b. - Les batraciens de la région de Gbakobo (Côte d'Ivoire). Mémoire de l'Institut fondamental de l'Afrique noire (A) 29: 218-294.

LAMOTTE M. 1969. — Le parc national du Niokolo-Koba, Fascicule III; XXX. Amphibiens (deuxième note). Mémoire de l'Institut fondamental de l'Afrique noire (A) 84: 420-426.

LAMOтTE M. 1971. — Le Massif des Monts Loma (Sierra Leone), Fasciule I; XIX. Amphibiens. Mémoire de l'Institut fondamental d'Afrique noire (A) 86: 397-407.

LAmotTe M. \& Ohler A. 1997. — Redécouverte de syntypes de Rana bibroni Hallowell, 1845, désignation d'un lectotype et description d'une espèce nouvelle de Ptychadena (Amphibia, Anura). Zoosystema 19: 531-543. http://sciencepress.mnhn.fr/fr/ periodiques/zoosystema/19/4/redecouverte-de-syntypes-de-ranabibroni-hallowell-1845-designation-d-un-lectotype-et-descriptiond-une-espece-nouvelle-de-ptychadena-amphibia-anura

Lamotte M. \& Ohler A. 2000. - Révision des espèces du groupe de Ptychadena stenocephala (Amphibia, Anura). Zoosystema 22: 569-583. http://sciencepress.mnhn.fr/fr/periodiques/ zoosystema/22/3/revision-des-especes-du-groupe-de-ptychadenastenocephala-amphibia-anura

LAmotTe M. \& PerRet J. L. 1963. - Contribution à l'étude des batraciens de l'Ouest Africain XV - Le développement direct de l'espèce Arthroleptis poecilonotus Peters. Bulletin de l'Institut fondamental d'Afrique noire (A) 25: 277-284.

LAMOTTE M. \& XAVIER F. 1981. — Les Amphibiens de l'Afrique de l'Ouest, in Durand J. R. \& Leveque C. (eds), Faune et Flore aquatiques de l'Afrique Sahélo-soudanienne, Editions de l'Office de la Recherche Scientifique et Technique d'Outre-Mer 2:773-816.

LAMPERT K. P. 2001. - Alternative life history strategies in the West African reed frog, Hyperolius nitidulus. Dissertation zur Erlangung des naturwissenschaftlichen Doktorgrades der Bayerischen Julius-Maximilians-Universität Würzburg. Germany, 168 p.

LANZA B. 1981. - A check-list of the Somali amphibians. Monitore zoologico Italiano, n.s., Supplemento 15: 151-186.

LARGEN J. M. 2001. - Catalogue of the amphibians of Ethiopia, including a key for their identification. Tropical Zoology 14: 307-402. https://doi.org/10.1080/03946975.2001.10531159

LAURENT R. F. 1972. - Tentative revision of the genus Hemisus Günther. Musée Royal d'Afrique Centrale, Sciences Zoologiques 194: 1-67.

Leaché A., RÖDEl M.-O., LinKEM C. W., Diaz R. E., Hillers A. \& FujITA M. K. 2006. — Biodiversity in a forest island: reptiles and amphibians of the West African Togo hills. Amphibian and Reptile Conservation 4: 22-45. https://doi.org/10.1514/journal.arc.0040018

LoumONT C. 1984. - Current distribution of the genus Xenopus in Africa and future prospects. Revue Suisse de Zoologie 91: 725746. https://doi.org/10.5962/bhl.part. 81578

LOVERIDGE A. 1950. - History and habits of the East African Bullfrog. Journal of the East Africa Natural History Society 19: 253-255.

MAYDELL H. J. 1983. — Arbres et arbustes du Sahel, leurs caractéristiques et leurs utilisations. Eschborn, Germany, GTZ. Journal d'Agriculture traditionnelle et de Botanique appliquée 31: 262-263.

MEE 1999. - Monographie nationale sur la diversité biologique au Burkina Faso. Secrétariat permanent du conseil national pour la gestion de l'environnement, Ouagadougou, Burkina Faso, 180 p.

MERH 2012. - Annuaire des statistiques de l'environnement. Edition de Juin 2015, Ouagadougou, Burkina Faso, 263 p. 
MohneKe M. 2011. - Unsustainable use of frogs in West Africa and resulting consequences for the ecosystem. Philosopical Doctorate dissertation, Humboldt Universität zu Berlin, Germany, $194 \mathrm{p}$.

MOHNEKE M., ZONGO B. \& RÖDEL M.-O. 2010a. — Les amphibiens du Burkina Faso, in Thiombiano A. \& Kampmann D. (eds), Biodiversity atlas of West Africa, volume 2, Ouagadougou and Frankfurt/Main: 298-302.

Mohneke M., OnadeKo A. B., Hirschfeld M. \& Rödel M.-O. 2010b. - Dried or fried: amphibians in local and regional food markets in West Africa. Traffic Bulletin 22: 117-128.

Mohneke M., OnadeKo A. B. \& Rödel M.-O. 2011. - Medicinal and dietary uses of amphibians in Burkina Faso. African Journal of Herpetology 60: 78-83. https://doi.org/10.1080/21 564574.2011 .564660

Nago A. G. S., Grell O., Sinsin B. \& Rödel M.-O. 2006. — The amphibian fauna of Pendjari National Park and surroundings, northern Benin. Salamandra 42: 93-108.

Nago A. G. S., Grell O., Sinsin B. \& RÖdel M.-O. 2009. The tadpole of Ptychadena schillukorum (Werner, 1908 "1907") (Amphibia: Anura: Ptychadenidae). Zootaxa 2115: 65-68. https://doi.org/10.11646/zootaxa.2115.1.6

Nago A. G. S., Penner J., Sinsin B. \& Rödel M.-O. 2010. Diversité des amphibiens au Benin: situation actuelle et future, in Sinsin B. \& KAMPMANN D. (eds), Biodiversity atlas of West Africa, volume 1, Cotonou and Frankfurt/Main: 394-397.

Ohler A. \& Dubois A. 2016. - The identity of the South African toad Sclerophrys capensis Tschudi, 1838 (Amphibia, Anura). PeerJ 4: 1-13. https://doi.org/10.7717/peerj.1553

OHLer A. \& Frétey T. 2008. - Statut du nom Arthroleptis milletihorsini, Angel, 1922 (Amphibia, Anura). Alytes 25: 173-175.

ONADEKO B. A. 2016. - Distribution, diversity and abundance of anuran species in three different vegetations habitats in southwestern Nigeria. Ethiopian Journal of environmental Studies and Management 9: 22-34. http://dx.doi.org/10.4314/ejesm.v9i1.3

ONADEKO B. A. \& RÖDEL M.-O. 2009. - Anuran surveys in south-western Nigeria. Salamandra 45: 1-14.

Padial J. M., Crochet P. A., Geniez P. \& Brito J. C. 2013. Amphibian conservation in Mauritania. Basic and applied Herpetology 27: 11-22. http://dx.doi.org/10.11160/bah.13002

Padial J. M. \& DE La Riva I. 2004. — Annotated checklist of the amphibians of Mauritania (West Africa). Revista Espanola de Herpetologia 18: 89-99.

Perret J. L. 1966. - Les amphibiens du Cameroun. Zoologische Jahrbücher für Systematik 8: 289-464.

Perret J. L. 1981. - Le statut de Ptychadena schubotzi (Sternfeld, 1917) (Amphibia, Ranidae). Bulletin de la Société Neuchâteloise des Sciences naturelles 104: 53-57.

Perret J. L. 1991. - Description de Ptychadena ingeri n. sp. (Anura, Ranidae) du Zaïre. Archives des Sciences de Genève 44: 265-281.

PiCKERSGILl M. 2007. - A redefinition of Afrixalus fulvovittatus (Cope, 1860) and Afrixalus vittiger (Peters, 1876) (Amphibia, Anura, Hyeroliidae). African Journal of Herpetology 56: 23-37. https://doi.org/10.1080/21564574.2007.9635551

Portik D. M. \& PAPENFuss T. J. 2015. - Historical biogeography resolves the origins of endemic Arabian toad lineages (Anura: Bufonidae): Evidence for ancient vicariance and dispersal events with the Horn of Africa and South Asia. Evolutionary Biology 15: 1-19. https://doi.org/10.1186/s12862-015-0417-y

Poynton J. C. \& Broadley D. G. 1987. - Amphibia Zambesiaca 3. Rhacophoridae and Hyperoliidae. Annals of Natal Museum 28: 161-229.

Poynton J. C., Loader S. P., Conradie W., Rödel M.-O. \& LIEDTKE H. C. 2016. - Designation and description of a neotype of Sclerophrys maculata (Hallowell, 1854), and reinstatement of Sclerophrys pusilla (Mertens, 1937) (Amphibia: Anura: Bufonidae). Zootaxa 4098: 73-94. http://doi.org/10.11646/zootaxa.4098.1.3
Rödel M.-O. 2000. - Herpetofauna of West Africa: Amphibians of the West African savannah. Edition Chimaira. Vol. 1. Germany, Frankfurt am Main, $300 \mathrm{p}$.

RÖDEL M.-O. 2003. - The amphibians of Mont Sangbé National Park, Ivory Coast. Salamandra 39: 91-110.

Rödel M.-O., Adeba P. J., Kouamé N. G. \& Penner J. 2010b. Les amphibiens de la Côte d'Ivoire, in Konaté S. \& KampMANN D. (eds), Biodiversity atlas of West Africa. Abidjan and Frankfurt/Main 3: 218-225.

Rödel M.-O. \& BAngoura M. A. 2004. - A conservation assessment of amphibians in the Forêt classée du Pic de Fon, Simandou Range, southeastern Republic of Guinea, with the description of a new Amnirana species (Amphibia Anura Ranidae), Tropical Zoology 17: 201-232. https://doi.org/10.1080/0 3946975.2004 .10531206

RÖdel M.-O., BANgOura M. A. \& BÖhme W. 2004. - The amphibians of south-eastern Republic of Guinea (Amphibia: Gymnophiona, Anura). Herpetozoa 17: 99-118.

RÖDEL M.-O. \& BRAUN U. 1999. - Associations between anurans and ants in a West African savanna (Anura: Microhylidae, Hyperoliidae and Hymenoptera: Formicidae). Biotropica 31: 178-183. https://doi.org/10.2307/2663971

RÖdel M.-O., Brede C., Hirschfeld M., Schmitt T., Favreau P., STÖCKLIN R., Wunder C. \& MeBs D. 2013. - Chemical camouflage - A frog's strategy to co-exist with aggressive ants. PLoS ONE 8: e81950. https://doi.org/10.1371/journal.pone.0081950

RÖDEL M.-O. \& ERNST R. 2004. - Measuring and monitoring amphibian diversity in tropical forests. I. An evaluation of methods with recommendations for standardization. Ecotropica 10: 1-14

RÖDEL M.-O. \& ERnST R. 2003. - The amphibians of Marahoué and Mont Péko National Parks, Ivory Coast. Herpetozoa 16: 23-39.

RÖDEL M.-O. \& GLOS J. 2019. - Herpetological surveys in two proposed protected areas in Liberia, West Africa. Zoosystematics and Evolution 95: 15-35. https://doi.org/10.3897/zse.95.31726

RÖdel M.-O., LAMPERT K. P. \& LinSENMAIR K. E. 2006. — Reproductive biology of the West African savannah frog Hyperolius nasutus Günther, 1864 (Amphibia: Anura: Hyperoliidae). Herpetozoa 19: 3-12.

Rödel M.-O., Sandberger L., Penner J., Mané Y. \& Hillers A. 2010a. - The taxonomic status of Hyperolius spatzi Ahl, 1931 and Hyperolius nitidulus Peters, 1875 (Amphibia: Anura: Hyperoliidae). Bonn zoological Bulletin 57: 177-188.

Rödel M.-O., Spieler M., Grabow K. \& BÖCKHEler C. 1995. Hemisus marmoratus (Peters, 1854) (Anura: Hemisotidae), Fortpflanzungsstrategien eines Savannenfrosches. Bonner zoologische Beiträge 45: 191-207.

Salvador A. 1996. - Amphibians of northwest Africa. Smithsonian herpetological Information Service 109: 1-45. https://doi. org/10.5479/si.23317515.109.1

SánCHeZ-Vialas A., Calvo-Revuelta M. \& Márquez R. 2017. Ptychadena in Mauritania and the first record of Ptychadena schillukorum. Zookeys 673: 125-133. https://doi.org/10.3897/ zookeys.673.10265

SCHIØтZ A. 1964. - A preliminary list of amphibians collected in Ghana. Videnskabelige Meddelelser fra dansk Naturhistorik Forening 127: 1-17.

Schiøtz A. 1967. - The treefrogs (Rhacophoridae) of West Africa. Spolia zoologica Musei hauniensis 25: 1-346.

SchiøтZ A. 1999. - Treefrogs of Africa. Edition Chimaira, Germany, Frankfurt am Main, 350 p.

Segniagbeto G. H., Bwossidjaou J. E., Dubois A. \& Ohler A. 2007. — Les amphibiens du Togo: état actuel de connaissance. Alytes 24: 72-90.

Sow A. S., Gonçalves D. V., Sousa F. V., Martínez-Freiría F., Santarém F., Velo-Antón G., Dieng H., Campos J. C., Diagne S. K., BoratyŃSKi Z. \& Brito J. C. 2017. — Atlas 
of the distribution of amphibians and reptiles in the Diawling National Park, Mauritania. Basic and applied Herpetology 31: 101-116. http://dx.doi.org/10.11160/bah.87

SP/CONEDD 2010. - Burkina Faso. Convention sur la diversité biologique: quatrième rapport national à la conférence des parties. Ouagadougou, Burkina Faso, 119 p.

SPIELER M. 1997. - Radio-telemetrische Untersuchungen zur Laichplatzwahl eines westafrikanischen Raniden, in HENLE K. \& VEITH M. (eds), Naturschutzrelevante Methoden der Feldherpetologie, Mertensiella 7: 203-220.

STEWART M. M. 1967. — The amphibians of Malawi. State University Press, New York, USA, 163 p.

Tandy M., Tandy J., Keith R. \& DufF-MacKay A. 1976. — New species of Bufo (Anura: Bufonidae) from Africa's dry savannahs. Pearce Sellards Series. Texas memorial Museum 4: 1-20.

Thiombiano A., Schmidt M., Kreft H. \& Guinko S. 2006. Influence du gradient climatique sur la distribution des espèces de Combretaceae au Burkina Faso (Afrique de l'Ouest). Candollea 61: 189-213.

Vences M., Kosuch J., RÖdel M.O., LÖtTers S., Channing A., GLAW F. \& BÖHME W. 2004. - Phylogeography of Ptychadena mascareniensis suggest transoceanic dispersal in a widespread African-Malagasy lineage. Journal of Biogeography 31: 593-601. https://doi.org/10.1046/j.1365-2699.2003.01031.x
Wasonga V. D. \& Channing A. 2013. - Identification of sand frogs (Anura: Pyxicephalidae: Tomopterna) from Kenya with the description of two new species. Zootaxa 3734: 221-240. http:// dx.doi.org/10.11646/zootaxa.3734.2.7

WELLS K. D. 2007. - The ecology and behaviour of amphibians. The University of Chicago Press, Chicago. 1162 p.

WERNER F. 1908 (1907). — Ergebnisse der mit Subvention aus der Erbschaft Treitl unternommenen zoologischen Forschungsreise Dr. Franz Werner's nach dem ägyptischen Sudan und NordUganda. XII. Die Reptilien und Amphibien. Sitzungsberichte der Kaiserlichen Akademie der Wissenschaften, MathematischNaturwissenschaftliche Classe 116: 1823-1926.

WiLson L. \& CHANNing A. 2019. - A new sand frog from Namaqualand, South Africa (Pyxicephalidae: Tomopterna). Zootaxa 4609: 225-246. http://dx.doi.org/10.11646/zootaxa.4609.2.2

Zimkus B. M., Lawson L. P., Barej M. F., Barratt C. D., Channing A., Dash K. M., Dehling M., Du Preez L., Gehring P. S., Greenbaum E., Gvoždík V., Harvey J., Kielgast J., Kusamba C., Nagy Z. T., Pabijan M., Penner J., Rödel M.-O., Vences M. \& LÖTTERS S. 2017. — Leapfrogging into new territory: how Mascarene ridged frogs diversified across Africa and Madagascar to maintain their ecological niche. Molecular Phylogenetics and Evolution 106: 254-269. http://dx.doi.org/10.1016/j. ympev.2016.09.018 